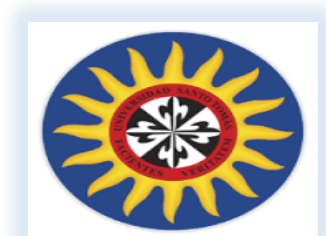

UNIVERSIDAD SANTO TOMAS

FACULTAD DE DERECHO

MAESTRÍA EN DERECHO PÚBLICO

X COHORTE

\title{
EL PROCEDIMIENTO ABREVIADO DE LA LEY 1476 DE 2011, UNA MIRADA ANALÍTICA DEL EJERCICIO DEL DERECHO DE DEFENSA
}

\author{
Presentado por: \\ JOHAN ALIRIO CORREA HINESTROZA \\ Tutor: \\ DR. JORGE ALBERTO GIRALDO RIVERA
}

Bogotá D.C. marzo 2018 
A mi padre, a quien respeto y admiro. 


\section{AGRADECIMIENTOS}

A Dios por brindarme la oportunidad de seguir adquiriendo conocimientos en materia jurídica y por permitirme hacer parte del X cohorte de la Maestría en Derecho Público de la Universidad Santo Tomas.

A mi Esposa Naby e Hijos, Valeria y Juan David, por su comprensión, tolerancia y apoyo brindado durante mis ausencias relacionadas con el adelanto de mis estudios de maestría en derecho público en la Capital Colombiana.

Al doctor Jorge Alberto Giraldo Rivera, jurista, profesor, asesor, quien con su invaluable aporte, ha permitido la materialización de este trabajo y mi crecimiento académico y profesional. Mis más sinceros agradecimientos y respecto. 


\section{Índice}

INTRODUCCIÓN 11

Capítulo Primero 17

ASPECTOS GENERALES Y ESPECÍFICOS QUE RODEAN LA INSTITUCIÓN DEL PROCEDIMIENTO ABREVIADO: UNA MIRADA DESDE LA NOCIÓN DE BIEN PÚBLICO, PATRIMONIO PÚBLICO Y RESPONSABILIDAD ADMINISTRATIVA Y FISCAL

SECCIÓN 1. EL PLANTEAMIENTO DE UNA DICOTOMÍA EN EL PROCEDIMIENTO ABREVIADO: PERSPECTIVA DESDE VARIOS DOCTRINANTES 27

A. El procedimiento abreviado de ley 1476 de 2011: visto desde su generalidad y especificidad 31

B. Análisis del procedimiento abreviado desde otras áreas: disciplinaria ley 1015 de 2006

y Procedimiento verbal de responsabilidad fiscal. Ley 1474 de 2011 36

SECCIÓN 2. LOS EFECTOS ECONÓMICOS EN LA APLICACIÓN DEL PROCEDIMIENTO ABREVIADO DESDE LA ÓPTICA DE LA ADMINISTRACIÓN _ 43

A. Factores económicos que inciden en la activación del procedimiento abreviado _ 44

B. Las entidades que ejercen la facultad de aplicación del procedimiento abreviado: según su competencia 54

Capitulo Segundo 57

LOS TÉRMINOS PROCESALES EN EL PROCEDIMIENTO ABREVIADO VISTO DESDE EL ÁMBITO JURISPRUDENCIAL Y PRÁCTICO DOS ASPECTOS QUE DESCUBREN POSIBLES VULNERACIONES AL DEBIDO PROCESO 57

SECCIÓN 1. BREVE MIRADA DE LOS TÉRMINOS PROCESALES DESDE LAS ESFERAS DEL PLAZO RAZONABLE, INCUMPLIMIENTOS Y EXCESIVA BREVEDAD A LA LUZ DE LA JURISPRUDENCIA COLOMBIANA___ 61

A. Los términos procesales según el Consejo de Estado ___ 62

B. Los términos procesales según la Corte Constitucional ___ 67

SECCIÓN 2. EL ASPECTO PRÁCTICO Y SUBJETIVO QUE ENCIERRA EL PROCEDIMIENTO ABREVIADO Y SU RELACIÓN CON EL DEBIDO PROCESO _ 78

A. El procedimiento abreviado: análisis de casos desde la óptica del debido proceso a varias decisiones de la administración 79

B. Planteamiento de un plazo razonable en el procedimiento abreviado que guarde garantías referidas al debido proceso 98

CONCLUSIONES 101

ANEXO \# 1. 109

BIBLIOGRAFÍA 117 


\section{INTRODUCCIÓN}

El principio de dignidad humana, establecido en el artículo $1^{\circ}$ de la Ley 1476 de 2011, nos muestra de entrada una norma que pretende adelantar procedimientos basados en el respeto al ser humano, de igual forma prevé un trato digno al servidor público que se encuentre sometido a las decisiones que la precitada norma dispone, dicho principio a su vez ha sido catalogado por varios autores entre ellos Marín Castán y Michelini, como uno de los más importantes que atañen los distintos escenarios de la vida en sociedad. Por consiguiente esta temática estará siempre sometida desde la óptica de la dignidad humana como garantía constitucional y legal a las decisiones y actuaciones proferidas por los funcionarios encargados de adelantar el procedimiento abreviado de la norma en mención. De igual forma el debido proceso es otro principio que juega un papel importante no solo para esta temática sino para todos los aspectos que conciernen las relaciones humanas en escenarios donde se ponga en entredicho los derechos y deberes de las personas, este principio será desarrollado desde la óptica de autores como Carvajal, Lopez Toro y Taruffo, quienes mostrarán de igual manera el valor que este consagra, referente a relaciones jurídicas. Asimismo el artículo 29 de la Constitución Política de Colombia, y varias sentencias de la Corte Constitucional, lo presentan como una de las garantías constitucionales más importantes para el desarrollo de actuaciones tanto judiciales como administrativas, y las dimensiones que en su literatura consagra, estableciendo entre ellas: (i) Juez Natural, (ii) favorabilidad, (iii) presunción de inocencia, (iv) derecho a la defensa técnica y material, (v) contradicción y (vi) publicidad. Del mismo modo el derecho de defensa y contradicción es sin duda alguna, una de las 
garantías legales más relevante para los escenarios judiciales y administrativas, a través del cual el investigado goza de la posibilidad de presentar y controvertir las pruebas que se alleguen en su contra, presentar recursos ante las decisiones que considere se enmarcan en contra de sus intereses, así como presentar alegatos de conclusión y demás formas que se establezcan en determinados procesos en aras de materializar al máximo los principios referidos. Para que esta garantía constitucional se desarrolle de la mejor manera posible, es necesario que existan tiempos adecuados, es decir que cada etapa procesal disponga de tiempos o plazos razonables que garanticen que el investigado ejerza su derecho a la defensa y contradicción en el marco de los principios de dignidad humana y debido proceso, ejerciendo el derecho que le asiste como investigado de forma óptima. Teniendo como referencia lo anterior, este trabajo se enfatizará en estudiar el procedimiento abreviado establecido en el artículo 94 de la Ley 1476 de 2011, desde la dimensión cuarta y quinta, toda vez que se plantea como problema jurídico, que el procedimiento abreviado establece términos procesales muy cortos, por tanto limita el ejercicio del derecho de defensa técnica y material, la posibilidad de presentar y controvertir pruebas, ello permite que se genere una lesión o vulneración los principios de dignidad humana y debido proceso, para lo cual se referenciarán autores entre ellos los profesores Pierce Zamora y Julio Maier, quienes expondrán posturas contrarias en torno al procedimiento abreviado.

En ese orden de ideas, y partiendo de la hipótesis que los tiempos establecidos en el procedimiento abreviado de la precitada norma, podrían ser violatorios del principio de dignidad humana y debido proceso, toda vez que las actuaciones según lo dispone el artículo 94 de la ley en mención, se surten en un plazo de ocho (8) días. Disposición que establece de entrada que se llevará a cabo una investigación bajo unos tiempos muy ajustados, desconociendo el respeto que se le debe a la persona y más aún si sus actos se encuentran 
siendo reprochados por la administración, máxime cuando sus decisiones lo afectan. Asimismo se menoscaba gravemente el ejercicio de la defensa y contradicción, dado que en la mayoría de situaciones se requiere de tiempos razonable para adelantar el estudio de los casos y establecer una defensa firme ante el reproche de los actos a la luz de los escenarios judiciales o administrativos. Por lo anterior se planteó como objetivo general determinar si las disposiciones del artículo 94 de la ley 1476 de 2011 vulneran los principios de dignidad humana y debido proceso, de cara al ejercicio del derecho de defensa y contradicción. Asimismo de manera específica, analizar el procedimiento abreviado de la ley 1476 de 2011 desde la perspectiva de los principios de dignidad humana y debido proceso, estudiar la jurisprudencia del Consejo de Estado y de la Corte Constitucional que habla de los términos procesales, en cuanto al plazo razonable, excesiva brevedad de los términos, cumplimientos e incumplimiento de términos por parte de los despachos judiciales y administrativos y establecer a partir de casos, como se ejerce el derecho de defensa y contradicción y el papel que juegan los principios de dignidad humana y debido proceso de cara a los mismos. Por consiguiente los objetivos trazados en la presente temática desde el aspecto general y objetivo, permitirán brindar respuesta a la pregunta que se ha planteado como problema de investigación.

Por consiguiente y en aras de explicar un poco más en qué consisten estos objetivos, se estructuraron una serie de capítulos, secciones y subsecciones, con el ánimo de constituir de una manera general y específica el problema y el desarrollo de la hipótesis, hasta llegar a la conclusión misma que nos permitió dar a conocer los resultados que la navegación doctrinal, jurídica y casuística nos arrojó. En ese sentido, la doctrina y la jurisprudencia colombiana, nos brindaron insumos importantes en la temática investigada, toda vez que mediante ella se han construido importantes teorías, las cuales son desarrolladas en muchas de las normas que 
regulan la sociedad hoy en día. Por lo tanto se hizo necesario estudiar el procedimiento abreviado desde varios aspectos como el plazo razonable, excesiva brevedad, cumplimientos e incumplimientos de términos procesales en el escenario judicial y administrativo, partiendo de la base que los tiempos establecidos en el artículo 97 de la norma en cita vulnera los principios de dignidad humana y debido proceso, violando a su vez el derecho de defensa y contradicción.

En ese orden de ideas, en el CAPÍTULO PRIMERO, se abordan los aspectos generales y específicos que rodean la institución del procedimiento abreviado, desde la noción de bien público, patrimonio público y responsabilidad administrativa y fiscal, con el objetivo de familiarizarse con el tema y dar a conocer conceptos importantes del procedimiento abreviado. Asimismo en la SECCIÓN 1, se plantea una dicotomía en torno al objeto de estudio, la cual es vista desde el ámbito de la doctrina, a través de la misma varios autores exponen escenarios y argumentos diferentes que defienden o rechazan el procedimiento abreviado.

En la parte literal A, se realiza una descripción del procedimiento abreviado, desde la regulación del artículo 94 de la Ley 1476 de 2011, con el propósito de poner en la temática planteada, la norma que lo regula y su desarrollo. Asimismo en la parte literal B, se muestra desde la perspectiva disciplinaria y fiscal, cómo se desarrolla el procedimiento abreviado desde dichas jurisdicciones, con el fin de compararlo con el procedimiento regulado en la precitada norma donde se investiga la pérdida y daño de bienes de propiedad del Ramo de la Defensa Nacional.

De la misma forma en la SECCIÓN 2, se realizó análisis del procedimiento abreviado de la Ley 1476 de 2011, desde el punto de vista económico, exponiendo aspectos importantes como el factor de competencia y activación de la investigación de carácter abreviada, el cual 
es establecido normativamente por la cuantía del bien perdido o dañado, toda vez que no debe supera los dos (2) Salarios Mínimos Legales Mensuales Vigentes, en tal sentido fue necesario efectuar análisis desde varios puntos de vista, como el material e inmaterial y la importancia de esta figura para el ramo de la defensa nacional. Dentro del aspecto material se analizan los gastos en los que incurre la administración para poner en marcha las investigaciones relacionadas con la pérdida o daño de bienes de propiedad de las fuerzas armadas, tales como pago de funcionarios, oficinas, papelería entre otros gastos. Por su parte dentro del aspecto inmaterial se exterioriza la importancia que tiene el procedimiento abreviado al interior del Ministerio de Defensa Nacional y sus Entidades adscritas y vinculadas a la Fuerza Pública, es decir establecer el costo beneficio que tendrá el Estado con la activación de investigaciones por este medio jurídico.

En el CAPITULO SEGUNDO, se estudian los términos procesales del procedimiento abreviado desde el ámbito jurisprudencial y práctico, teniendo en cuenta que la Corte Constitucional y el Consejo de Estado son instituciones muy importantes en el desarrollo jurídico Colombiano. Por tanto se aprende como miran estas instituciones la figura jurídica del procedimiento abreviado y su relación con el debido proceso constitucional, igualmente se efectúa el análisis de casos investigados desde su desarrollo normativo en aplicación en estricto sentido de la norma, de igual forma se realiza un análisis de casos, brindando dentro de las etapas procesales los tiempos y garantías referidas a los principios de dignidad humana y debido proceso. En la SECCIÓN 1, se efectúa una breve mirada de los términos procesales desde las esferas del plazo razonable, incumplimientos y excesiva brevedad a la luz de la jurisprudencia Colombiana, en aras de consolidar argumentos válidos que permitan llegar a proponer un plazo adecuado para el desarrollo del procedimiento abreviado establecido en el artículo 94 de la Ley 1476 de 2011, además se estudia la jurisprudencia del Consejo de Estado 
y de la Corte Constitucional de Colombia en lo referente a los términos procesales (parte literales A y B).

En la SECCIÓN 2, se aborda el aspecto práctico y subjetivo que encierra el procedimiento abreviado y su relación con el debido proceso. En tal sentido en el primer aspecto, se efectúa un análisis a varios casos fallados por la administración, con el fin de establecer posibles vulneraciones al derecho de defensa como garantía referida al debido proceso constitucional (literal parte A). De igual forma en la (parte literal B), se fundamenta el planteamiento de un plazo razonable que respete los tiempos en los que se debe desarrollar el procedimiento abreviado establecido en el artículo 94 de la Ley 1476 de 2011, como garantía de la efectividad que debe regir toda clase de actuación tanto judicial como administrativa, en lo relacionado al ejercicio del derecho de defensa y contradicción. De igual forma se concluye, con la presentación de los resultados que el análisis mismo brinda del tema, respondiendo de esa forma a la pregunta problema que se planteó al inicio del trabajo.

El propósito de esta labor es brindar un aporte en conocimiento de la figura jurídica del procedimiento abreviado, de igual forma dar a conocer insumos que puedan servir a la hora de resolver problemas de cara a los escenario que convergen al interior de una investigación de carácter abreviada adelantada por alguna de las instituciones que integran el ramo de la defensa nacional en Colombia. Asimismo comprender los aspectos importantes de las disposiciones contenidas en el artículo 94 de la Ley 1476 de 2011 y la debida relación con los principios, derechos y deberes, consagrados en la Constitución, la Ley, la doctrina y la jurisprudencia. 
Capítulo Primero

\section{ASPECTOS GENERALES Y ESPECÍFICOS QUE RODEAN LA INSTITUCIÓN DEL PROCEDIMIENTO ABREVIADO: UNA MIRADA DESDE LA NOCIÓN DE BIEN PÚBLICO, PATRIMONIO PÚBLICO Y RESPONSABILIDAD ADMINISTRATIVA Y FISCAL}

Es importante previamente al desarrollo de la temática, definir con claridad, el concepto de bien público y bien fiscal, en aras de generar una idea clara de ambos, para lo cual se abordará de manera profunda el estudio del primero de ellos, considerando que respecto a los bienes públicos o de uso público, la Constitución Política de Colombia, establece en el artículo 63 que son inalienables, imprescriptibles e inembargables, dentro de esta categoría se encuentran los parques naturales, las tierras comunales de grupos étnicos, las tierras de resguardo, el patrimonio arqueológico de la Nación y los demás bienes que determine la ley. De igual forma el artículo 674 del Código Civil Colombiano, define los bienes públicos o de uso público como aquellos cuyo dominio pertenece a la República, es decir que "los bienes públicos sólo pueden ser provistos por el Estado” (Braña, 2004, pág. 179). Por consiguiente gozan de una categorización como: "bienes de dominio público, bienes comunales, bienes patrimoniales y bienes del patrimonio nacional" (Vanestralen, 2004, pág. 216). Asimismo establece que si los bienes pertenecen a todos los habitantes de un territorio, como las calles, plazas, puentes y caminos, se llaman bienes de la unión de uso público o bienes públicos del territorio, para entrar más en detalle el siguiente autor realiza un análisis mucho más preciso en torno a los bienes de uso público para lo cual expone:

Un análisis elemental y sencillo nos lleva a observar que los bienes incluidos en el dominio público lo son naturalmente o artificialmente (instrumental). Los ríos, las playas y los mares son 
tradicionalmente (desde la época romana) catalogados como bienes públicos por su simple naturaleza; en cambio, las plazas, las calles y los edificios se catalogaron de acuerdo con su utilización y, obviamente, como obras construidas por la mano del hombre. La Constitución hace una primera catalogación sobre los bienes de dominio público natural como la zona marítimoterrestre, las playas, el mar territorial y los recursos naturales de la zona económica y la plataforma continental, y la legislación en cada caso particular se encarga de completar el panorama calificando ciertos bienes como de dominio público (yacimientos minerales, recursos geológicos, hidrocarburos, el espacio radioeléctrico, etc.). (Vanestralen, 2004, pág. 222)

No obstante si los bienes de la Unión cuyo uso no pertenece generalmente a los habitantes, se llaman bienes de la Unión o bienes fiscales. En tal sentido el Consejo de Estado Colombiano, asegura que, con la entrada en vigencia de la Constitución Política de 1991, esa clasificación tradicional entre bienes fiscales y bienes de uso público se quedó corta, toda vez que existen categorías de bienes que cuentan con características particulares que no se acomodan a las de una u otra especie. Para (Pimiento, 2011), existen unos bienes de uso público universales como los ríos, el mar, o el espectro electromagnético, los cuales no se encuentran dentro del articulado de la Carta Constitucional, no obstante los bienes del Estado afectados a un servicio público directamente prestado por la Administración (servicio público "propio"), pertenecen al dominio público. En la especie de bienes públicos destinados al uso público "indirecto"; ejemplos: jardines zoológicos; museos; ferrocarriles y aviones para transporte de personas y cosas; etc. Tratándose de bienes "públicos", rigen a su respecto en todo su rigor las consecuencias de la "inalienabilidad" y de la "imprescriptibilidad". (Marienhoff S, 1994, pág. 41). De igual forma "se destaca en este momento, para nuestros efectos, sólo las que están fuera del comercio, en las cuales se comprendían, según los romanos, una serie de bienes sometidos a unas reglas propias que conllevaban en su esencia 
los atributos de la inalienabilidad e imprescriptibilidad" (Vanestralen, 2004, pág. 213). Del mismo modo para la Constitución Política de Colombia los bienes de uso público, son inalienables, imprescriptibles e inembargables, es importante definir antes de avanzar en el tema estos conceptos considerados de suma importancia para la investigación que se adelanta, en ese orden de ideas el (Diccionario del Español Jurídico), define las anteriores nociones de la siguiente manera: inalienable: "Dicho de un bien de dominio público: In susceptible de ser enajenado", es decir "muchos bienes de dominio público es difícil atribuirles un valor de mercado (o valor razonable), porque son inalienables" (Catarino Rua, 2016, pág. 85). Imprescriptibles: “Que no puede ser adquirido por prescripción adquisitiva. Lo que no cabe adquirir por usucapión”, es decir, "por el «hecho» de que las cosas están en el uso público no son susceptibles de posesión individual, requisito primero de una prescripción" (Garcia De Enterría, 1954, pág. 24) Inembargable: "No susceptible de ser objeto de un mandamiento de ejecución o providencia de embargo", explicado de otra manera, "constituye una excepción calificada que favorece a los órganos de la administración del Estado, que impide que pueda operar en su contra una medida ordinaria de garantía del cumplimiento de sentencias condenatorias en dinero" (Ferrada Bórquez, 2007, pág. 86). Por su parte (Pimiento, 2011) ${ }^{1}$ expresa que los bienes fiscales son considerados bienes de la administración, destinados a cumplir un servicio público, no obstante su régimen se hace asimilable a la de la propiedad privada. También es importante tener en cuenta "en tanto que si el uso no pertenece por lo general a todos los habitantes, se denominan bienes fiscales" (Carrillo Ballesteros, 2006, pág. 25). Entretanto la clasificación vista a hasta este momento

\footnotetext{
${ }^{1}$ PIMIENTO ECHEVERRI, Julián. Derecho Administrativo de Bienes. Reflexiones en torno a la división de los bienes públicos en el Código Civil. Revista de Derecho Privado, n 21 julio-diciembre de 2011, pp. 207232.
} 
nos deja entrever que existen dos clases de bienes los cuales a su vez están directamente relacionados con el Estado dichos "bienes cuyo uso no pertenece generalmente a todos los habitantes, que serán llamados bienes fiscales" (Pimiento, 2011, pág. 218). De lo anterior, se podría colegir, que los bienes fiscales son los edificios, carros, motos, muebles y enseres, en general todos aquellos que de una u otra forma prestan un servicio para el cumplimiento de las labores de la administración pública, por tanto así son considerados.

Por su parte el patrimonio del Estado está fuertemente amparado en el contexto nacional desde la óptica constitucional, legal y jurisprudencial, en ese sentido, los artículos $6^{2}$ y $124^{3}$ de la Constitución Política de Colombia, establecen que los servidores públicos son responsables ante las autoridades por infringir la Constitución y las leyes, por la omisión o extralimitación en el ejercicio de sus funciones, determinando de igual forma su responsabilidad y la manera de hacerla efectiva, asimismo el artículo $90^{4}$ de la norma superior establece la responsabilidad patrimonial del Estado, la cual se debe asumir por la conducta dolosa o gravemente culposa de uno de sus agentes, cuando esta recaiga sobre un particular que no esté obligado a soportar dicho daño o menoscabo, no obstante el Estado tiene la facultad de repetir contra el agente que causó tal conducta, estando obligado a responder patrimonialmente por sus actos, dicho de otro modo se ejerce acción de repetición "una vez que el Estado haya respondido por las conductas injustificadamente erróneas o arbitrarias del fiscal o funcionario" (Soler Pedroza \& Jiménez, 2009, pág. 76).

\footnotetext{
${ }^{2}$ C.N. Artículo 6. Los particulares sólo son responsables ante las autoridades por infringir la Constitución y las leyes. Los servidores públicos lo son por la misma causa y por omisión o extralimitación en el ejercicio de sus funciones.

${ }^{3}$ C.N. Artículo 124.La ley determinará la responsabilidad de los servidores públicos y la manera de hacerla efectiva.

${ }^{4}$ C.N. Artículo 90.El Estado responderá patrimonialmente por los daños antijurídicos que le sean imputables, causados por la acción o la omisión de las autoridades públicas.

En el evento de ser condenado el Estado a la reparación patrimonial de uno de tales daños, que haya sido consecuencia de la conducta dolosa o gravemente culposa de un agente suyo, aquel deberá repetir contra éste.
} 
En lo que respecta a la responsabilidad administrativa por pérdida o daño de bienes del ramo de la defensa nacional, es preciso mencionar que recae exclusivamente en los servidores públicos del Estados, entre ellos los miembros de la fuerza pública, a su vez soportado a la luz de los artículos $123^{5}$ y $216^{6}$ de la Constitución Nacional, por consiguiente "la responsabilidad administrativa sobreviene por faltas cometidas en el desempeño del trabajo según las leyes y reglamentos respectivos” (Dermisaky Peredo, 2012, pág. 12). De igual importancia se encuentran: (i) ley 610 de $2000^{7}$, en esta ley se establece con claridad la competencia de la Contraloría General de la República, los principios de acción fiscal, gestión fiscal, que es el conjunto de actividades económicas, jurídicas y tecnológicas que realizan los servidores públicos y las personas de derecho privado que manejan o administran recursos o fondos públicos tendientes a la adecuada y correcta adquisición, planeación, conservación, administración, custodia, explotación, enajenación, consumo, adjudicación, gasto, inversión y disposición de los bienes públicos, de igual forma es “entendida la gestión fiscal como el conjunto de operaciones y procesos que desarrolla la administración en todos los niveles o los particulares que administran bienes públicos en ejercicio de funciones administrativas, tendientes al cumplimiento de los fines generales del Estado, el control fiscal, es considerada una actividad de estricto carácter administrativo que persigue el

\footnotetext{
${ }^{5}$ C.N. Artículo 123. Son servidores públicos los miembros de las corporaciones públicas, los empleados y trabajadores del Estado y de sus entidades descentralizadas territorialmente y por servicios.

Los servidores públicos están al servicio del Estado y de la comunidad; ejercerán sus funciones en la forma prevista por la Constitución, la ley y el reglamento.

La ley determinará el régimen aplicable a los particulares que temporalmente desempeñen funciones públicas y regulará su ejercicio.

${ }^{6}$ Artículo 216. La fuerza pública estará integrada en forma exclusiva por las Fuerzas Militares y la Policía Nacional.

Todos los colombianos están obligados a tomar las armas cuando las necesidades públicas lo exijan para defender la independencia nacional y las instituciones públicas.

La Ley determinará las condiciones que en todo tiempo eximen del servicio militar y las prerrogativas por la prestación del mismo.

${ }^{7}$ LEY 610 de 2000 "Por la cual se establece el trámite de los procesos de responsabilidad fiscal de competencia de las contralorías"
} 
aseguramiento de los intereses generales de la comunidad a través de un buen manejo de los recursos públicos y del cumplimiento de los fines del Estado" (Correa Gómez \& Pinzón Maldonado, 2012, pág. 177). Establece además como objeto de la responsabilidad fiscal, el resarcimiento de los daños ocasionados al patrimonio público como consecuencia de la conducta dolosa o culposa de quienes realizan gestión fiscal, también menciona que se pueden ocasionar daños o pérdidas de bienes que generen detrimento al patrimonio público que no sería de su competencia. (ii) Ley 87 de $1993^{\circ}$, esta normatividad es muy importante en las entidades y organismos del Estado, toda vez que busca en lo que respecta al manejo y conservación de bienes, proteger los recursos de la organización, buscando su adecuada administración ante posibles riesgos que lo afecten, además establece la adopción de normas para la protección y utilización racional de los recursos. (iii) Ley 734 de $2002^{9}$, en este código se consignan los deberes de todos los servidores públicos ${ }^{10}$ del Estado entre los que se encuentran en particular al tema expuesto, la vigilancia y salvaguardia de los bienes y valores que le han sido encomendados y cuidar que sean utilizados debida y racionalmente, de conformidad con los fines a que han sido destinados, de la misma forma responder por la conservación de los útiles, equipos, muebles y bienes confiados a su guarda o administración y rendir cuenta oportuna de su utilización.

De igual manera la Ley 1015 de $2006^{11}$, es aquella que expresa todos los comportamientos inapropiados de los miembros de la Policía Nacional en ejercicio de sus deberes y las consecuencia que estos traen, por tanto "falta disciplinaria, es aquella conducta activa o

\footnotetext{
${ }^{8}$ Ley 87 de 1993, "Por la cual se establecen normas para el ejercicio del control interno en las entidades y organismos del Estado y se dictan otras disposiciones

${ }^{99}$ Ley 734 de 2002 "Por la cual se expide el Código Disciplinario Único"

${ }^{10}$ Véase Ley 734 de 2002. Artículo 34. Los Deberes de todo servidor público

${ }^{11}$ Ley 1015 de 2006 "Por la cual se establece el régimen disciplinario de la Policía Nacional de Colombia"
} 
pasiva que transgrede o viola una norma jurídica relacionada con el incumplimiento de los deberes propios del cargo o función y que conlleve a extralimitación en el ejercicio de derechos, funciones y prohibiciones, violación del régimen de inhabilidades, incompatibilidades, impedimentos y conflicto de intereses, sin justificación alguna" (Reales Vega, 2016, pág. 161), determina además la responsabilidad para sus integrantes en lo que respecta al manejo y cuidado de los bienes ${ }^{12}$ y equipos que les han sido encomendados para el cumplimiento de su rol constitucional, la cual se enmarca dentro de la precitada norma como faltas gravísimas clasificada de la siguiente manera así: a). Extraviarlos, permitir que se pierdan, dañarlos, cambiarlos o desguazarlos, b) Incurrir en negligencia o actuar con impericia o imprudencia en su manejo, conservación o control c). Omitir la entrega o retardar el suministro de los elementos necesarios para su mantenimiento.

En lo que respecta al aspecto jurisprudencial, la sentencia C-840 de $2001^{13}$ de la Corte Constitucional analiza la demanda de inconstitucionalidad de algunos apartes de la ley 610 de 2000, además dista con claridad que es la gestión fiscal y quienes la realizan, diferenciando a su vez los daños que pueden causarse al patrimonio público por actividades distintas a la gestión fiscal. Por su parte el Consejo de Estado, a través del Consejero Ponente doctor Flavio

\footnotetext{
${ }^{12}$ Artículo 34. Faltas gravísimas. Numeral 21. Respecto de los bienes y equipos de la Policía Nacional, o de otros puestos bajo su responsabilidad, violar la ley, reglamentos o instrucciones superiores mediante las siguientes conductas:

a) Retenerlos, ocultarlos o apropiárselos;

b) Usarlos en beneficio propio o de terceros;

c) Darles aplicación o uso diferente;

d) Extraviarlos, permitir que se pierdan, dañarlos, cambiarlos o desguazarlos;

e) Entregarlos a personas distintas de su verdadero dueño;

f) Malversarlos o permitir que otros lo hagan;

g) Conducirlos u operarlos s in el debido permiso o autorización, en estado de embriaguez o bajo los efectos de sustancias que produzcan dependencia física o síquica.

${ }^{13}$ Corte Constitucional, demanda de inconstitucionalidad contra algunos apartes de los artículos 1, 4, 6, 12 y 41 de la ley 610 de 2002. MP. JAIME ARAUJO RENTERÍA, Demandante. ANDRÉS CAICEDO CRUZ.
} 
Augusto Rodríguez Arce ${ }^{14}$, precisa aspectos relacionados con la responsabilidad administrativa por pérdida, daño o deterioro de bienes ocasionado por personas o servidores públicos en ejercicio o no de gestión fiscal, indicando que “únicamente procede la derivación de responsabilidad fiscal cuando el hecho tenga relación directa con el ejercicio de actos propios de la gestión fiscal por parte de los presuntos responsables”, en el mismo sentido, hace claridad sobre la existencia de daños jurídicos, daños no imputables a la actividad antijurídica y daño antijurídico por conducta constitutiva de eventual falta disciplinaria, mencionando que el servidor público (disciplinado) que se vea inmerso en esta clase de investigaciones, puede de manera voluntaria hacer la restitución, devolución o reparación del bien o bienes para ejecutar o reducir las consecuencias disciplinarias.

A su vez dentro de los aspectos importantes de este apartado, se hace necesario establecer las diferencias que existen en la actualidad en lo que respecta a la responsabilidad fiscal y la responsabilidad administrativa, para mencionar que existe una responsabilidad administrativa del servidor público mediante la cual éste debe responder por los daños o pérdidas que se causen a bienes del Estado, siendo esta responsabilidad diferente a la responsabilidad fiscal, tomando como fuente de lo anterior en primera medida el código civil y la constitución política de 1991. Por lo anterior y siguiendo la línea del tiempo en lo que respecta a la normatividad de la responsabilidad administrativa por pérdida o daño de bienes, en el año de 1961 se expidió el primer decreto bajo el radicado 1255 del 10 de junio, por el cual se aprobó el Reglamento Fuerzas Militares (FF. MM. 4-001) Público de Procesos Administrativos, por pérdidas o daños de material de Guerra. Posteriormente este decreto fue

\footnotetext{
14 Consejo de Estado, Sala de Consulta y Servicio Civil. Consejero Ponente. Dr. FLAVIO AUGUSTO RODRÍGUEZ ARCE. Concepto No. 1497 de fecha (4) agosto de 2003. Hace claridad sobre aspectos relacionados con la gestión fiscal y la responsabilidad administrativa por pérdida o daño de bienes.
} 
subrogado por el artículo 5 del decreto 791 de 1979, por el cual se aprobó el Reglamento de Procesos Administrativos por pérdidas o daños de los bienes destinados al servicio del Ramo de Defensa Nacional, esta norma fue modificada por el decreto 1932 de 2000 en cuanto a las autoridades competentes para fallar las investigaciones administrativas que se adelantaban por pérdida o daño de bienes del material de las instituciones mencionadas. No obstante se hizo necesario ajustar el proceso administrativo por pérdida o daño de bienes destinados al ramo de la defensa nacional a los postulados de la Constitución Política de 1991, para lo cual el Congreso de la República expidió la ley 1476 de 2011 "Régimen de responsabilidad administrativa por pérdida o daño de bienes de propiedad o al servicio del Ministerio de Defensa Nacional, sus entidades adscritas o vinculadas a la fuerza pública”.

Con lo anterior, fue presentada toda la normatividad que ha presidido la responsabilidad administrativa de los servidores públicos en lo relacionado con la pérdida o daño de bienes del ramo de la defensa. Sin embargo, se hace necesario pasar al fondo del tema, el cual es dar a conocer las diferencias sustanciales entre la responsabilidad administrativa y la responsabilidad de índole fiscal. En ese orden de ideas, se relacionará la ley 42 de $1923^{15}$, mediante la cual se reorganizó la contabilidad oficial y se creó el departamento de contraloría, dicha ley estaba dirigida a adelantar un control jurídico contable respecto de la utilización de los bienes del Estado. Posteriormente se expidió la ley 20 de $1975^{16}$ y decretos reglamentarios 924 y 925 de 1976, a través del cual se estableció por el primero de ellos la estructura orgánica de la Contraloría General de la República y por el segundo los procedimientos generales de control fiscal y de auditoría, el alcance que deben tener el control previo y la contabilidad

\footnotetext{
${ }^{15}$ Ley 42 de 1923 "Sobre reorganización de la contabilidad oficial y creación del Departamento de Contraloría"

${ }^{16}$ Ley 20 de 1975 "Por la cual se modifican y adicionan las normas orgánicas de la Contraloría General de la República, se fijan sistemas y directrices para el ejercicio del control fiscal y se dictan otras disposiciones"
} 
general de la Nación y se dictan normas sobre estadística. Con base en la normatividad que se menciona, es que se establecen unos verdaderos procedimientos que pretenden ejercer un control fiscal en Colombia, señalando a su vez las etapas de control previo, control perceptivo y control posterior.

Así las cosas queda claro hasta este momento que la Contraloría es la que ejerce control fiscal en el país, adelantando las investigaciones en materia de responsabilidad fiscal, la cual se encamina a evaluar la legalidad del gasto y sus aspectos financieros, a funcionarios determinados, siempre y cuando se ocasionaren perjuicios en desarrollo de su gestión como: tesoreros, almacenistas, ordenadores del gasto etc. Y que tuvieran que rendir cuentas a la Contraloría General de la República. Mencionado lo anterior se colige, que la responsabilidad fiscal dista de la responsabilidad administrativa, considerando que la primera se basa en evaluar la legalidad del gasto y aspectos financieros y la segunda abarca a todo servidor público que ocasione daños o pérdidas a bienes del Estado. Otro aspecto para resaltar es que en la responsabilidad fiscal, el daño debe resarcirse, por su parte la responsabilidad administrativa obliga a reponer o pagar el bien perdido o dañado.

Una vez presentado los aspectos generales y específicos que encierran el procedimiento abreviado, y de igual forma haber introducido sobre varios temas importantes para el desarrollo de la presente temática, se hace importante traer a colación la dicotomía que surge de la figura jurídica del procedimiento abreviado, toda vez que existen doctrinantes que defienden esta institución y por el contrario otros la rechazan. Por tanto en la siguiente sección se relacionarán varios planteamientos de doctrinantes en la materia, con el propósito de conocer las posturas y los argumentos que guardan las mismas, en aras de conocer sus fortalezas o debilidades en el marco de la doctrina. 


\section{SECCIÓN 1. EL PLANTEAMIENTO DE UNA DICOTOMÍA EN EL PROCEDIMIENTO ABREVIADO: PERSPECTIVA DESDE VARIOS DOCTRINANTES}

En esta sección se hará alusión a la dicotomía que se presenta con relación a la figura del procedimiento abreviado, toda vez que para muchos es una figura positiva en la administración de justicia, habida cuenta que permite o facilita la tramitación rápida de casos puesto bajo los operadores jurídicos, de igual forma permite la evacuación de procesos acumulados en los distintos despachos judiciales o administrativos, al igual que sirve como una válvula de escape, ante la avalancha de procesos que normalmente se registran en los despachos. Por su parte otra perspectiva del tema en estudio, es que el procedimiento abreviado es una figura que vulnera derechos constitucionales, toda vez que no permite el ejercicio de una efectiva defensa material y técnica, dado la excesiva brevedad en los términos que esta clase de procedimientos suelen establecer. En ese orden de ideas, se relacionarán varios autores que ayudarán a establecer una posición en la dicotomía que se presenta en el procedimiento abreviado y que sirvan de fundamento o base a la hora de soportarla, en tal sentido para (Salvador Ma., 2010) ${ }^{17}$, el procedimiento abreviado es considerado una novedad importante para varias materias, en cuantías determinadas y limitadas, además del propósito de ponerle fin a prácticas administrativas injustificables y demasiadas extensas que alargan la tramitación de muchas causas. Por su parte (Natarén, $2011)^{18}$, sostiene que el procedimiento abreviado consiste en una salida alterna que permite dictar una sentencia de forma más rápida y de cuantía menor que en el procedimiento

\footnotetext{
17 SALVADOR Ma. Martin Valdivia. Formularios de Procedimientos Administrativos. 2010. ValladolidEspaña. Lex Nova S.A.

${ }^{18}$ NATARÉN NANDAYAPA. Carlos F. Las "Salidas Alternas" en el diseño del nuevo proceso penal: breves notas desde la experiencia de la reforma en las entidades de la federación. 2011. Revista: Instituto de Investigaciones jurídicas de la UNAM. Pp. 99-108.
} 
ordinario. En una posición un tanto diferente a la de los anteriores autores, (Cordero, 2001) ${ }^{19}$ observa el procedimiento abreviado como una figura positiva, que nace para intentar solucionar los problemas de congestión judicial y administrativa, caracterizado por la avalancha de asuntos, la trivialidad de mucho de ellos, rigidez y falta de medios de las salas. Dice además que dicho sistema se pretende que se convierta en la válvula de escape de la saturada jurisdicción; destacando además como características esenciales la reducción de trámites, concentración de actuaciones y ventilación de las cuestiones objeto de litigios. Los anteriores conceptos de autores destacados en el tema, transmiten una información o conocimiento respecto de saber de la aplicación del procedimiento administrativo abreviado desde el escenario jurídico, ahora bien es necesario definir el concepto como tal, para lo cual el (Diccionario del Español Jurídico, 2016) lo presenta de la siguiente manera: "Procedimiento administrativo que ha sido legalmente configurado con procedimientos más simples o sencillos que los de otro para ofrecer una tramitación más breve en asuntos determinados".

Ahora bien, se expondrán a continuación dos perspectivas la (i) desde el enfoque del derecho penal y la segunda desde el derecho administrativo, aclarando que el primer aspecto se presentará sólo a manera de información, toda vez que el tema de estudio conlleva una orientación desde el ámbito administrativo. Así las cosas, "El procedimiento abreviado es, en síntesis, el que permite al juez de garantía conocer y fallar una hipótesis penal, en forma rápida y resumida, sin pasar por el juicio oral a petición exclusiva del fiscal, mediante un acuerdo propuesto por éste que debe ser aceptado por el acusado y por el juez, si concurren

\footnotetext{
${ }^{19}$ CORDERO LOZANO. Fernando. El procedimiento abreviado en la nueva ley de la jurisdicción contenciosoadministrativa". Universidad de salamanca. 1, pp. 1-6.
} 
los demás requisitos legales”. (Nuñez, 2016, pág. 435). ${ }^{20}$ De igual forma otra crítica al procedimiento abreviado, está relacionada con que esta clase de procedimientos son violatorios de principios y derechos fundamentales y que no reglamenta la reparación del daño como tal, "El procedimiento abreviado, según el cual podría reducirse una pena por la aceptación de los hechos por parte del imputado, no reglamenta la reparación del daño, se desarrolla sin atender los principios de inmediatez, publicidad e igualdad procesal, y viola los derechos del imputado a la defensa, a un juicio previo a la pena y a no auto incriminarse". (Zamora, 2016, pág. 49) ${ }^{21}$. Por su parte otros autores manifiestan que "el procedimiento abreviado ha sido un instrumento para que tanto jueces, fiscales como defensores puedan disminuir su cantidad de trabajo". (Maier \& Bovino, 2001, pág. 127) ${ }^{22}$. De igual forma "posibilita materializar un causa eficiente, eficaz y efectiva, logrando al mismo tiempo una reactivación del aparato punitivo del Estado, el cual, actualmente es víctima del colapso de la administración de la justicia penal, tomándose en cuenta que la mayoría de casos son ventilados en procedimientos ordinarios, los cuales demandan tiempo, recursos y personal limitados. Por otra parte, el procedimiento abreviado solidifica el proceso de autonomía de la voluntad o del consenso en la resolución de conflictos jurídico penales, logrando en común acuerdo imponer la pena al procesado" (Burbano, 2017, pág. 191) ${ }^{23}$.

Como se observa hasta este momento, varios autores que han escrito sobre el procedimiento abreviado, lo han realizado desde dos clases de perspectivas, la primera desde el ámbito administrativo y la segunda desde el contexto de lo penal, en ambos escenarios

\footnotetext{
${ }^{20}$ NUÑEZ VASQUEZ. Cristóbal. El procedimiento abreviado.

${ }^{21}$ ZAMORA PIERCE, Jesús. (diciembre de 2016). Los peligros del procedimiento abreviado. V|lex. Disponible en: https://doctrina.vlex.com.mx/vid/peligros-procedimiento-abreviado-410400454.

${ }^{22}$ MAIER, Julio y BOVINO, Alberto. El procedimiento abreviado. (comps). Buenos Aires, Argentina: 2001. Editores del Puerto s.r.l. pág. 127.

${ }^{23}$ ENRÍQUEZ, Guillermo. El procedimiento abreviado como una forma de descongestión del sistema judicial penal. Revista de la Facultad de Jurisprudencia. 2017, No. 2, pp. 191-227.
} 
dicho procedimiento ha sido utilizado para darle celeridad a los procesos o para acortar los largos trámites que se adelantan en los despachos judiciales. En suma el procedimiento abreviado según los autores anteriormente referenciados es para finalizar determinado asunto en un plazo o término expedito. De igual forma estos autores coinciden en afirmar que el procedimiento abreviado está directamente vinculado con la cuantía o el asunto en su grado de importancia, es decir se colige que dependiendo de la cuantía establecida o la importancia del tema, el operador judicial establece el tramite a seguir dependiendo la jurisdicción donde se encuentre el negocio jurídico. Por otra parte hay varios autores que aseguran que el procedimiento abreviado es violatorio de principios y derechos, tales como principio de inmediatez, publicidad y de igualdad procesal, viola o vulnera de igual forma derechos como los que le deben asistir al investigado a una defensa técnica, a un juicio justo es decir anterior a la obtención de la pena y atenta directamente con el derecho constitucional que le asiste a todo procesado de no auto incriminarse.

Lo mencionado hasta el momento en lo relacionado con el tema de estudio, nos deja aún en la dicotomía planteada, es decir hasta aquí no se puede asegurar si el procedimiento abreviado es apropiado o no para la administración de justicia, toda vez que como bien se planteó en líneas anteriores se presentan varios argumentos o posturas que defienden el procedimiento abreviado y por otro lado de igual forma se muestran planteamientos negativos al respecto. En tal sentido, será necesario abordar otros temas relacionados con el presente estudio en aras de lograr una posible respuesta que permita con certeza inclinarnos por una de las dos posturas expuestas, para lo cual seguidamente se estudiará la naturaleza jurídica del procedimiento abreviado. 


\section{A. El procedimiento abreviado de ley 1476 de 2011: visto desde su generalidad y especificidad}

El problema jurídico que gira entorno a la norma que se expone, nos avoca al planteamiento del artículo 94 de la 1476 de $2011^{24}$, el cual vulnera el debido proceso en lo que respecta al derecho de defensa y contradicción, toda vez que los tiempos mediante los cuales se desarrolla el procedimiento abreviado son muy cortos, lo cual impide un ejercicio efectivo de los derechos antes mencionados, sin embargo la generalidad del tema exhibido nos conduce a poner de presente que el legislador estableció como principios ${ }^{25}$ de la norma referida los de dignidad humana y debido proceso, en tal sentido es preciso enfatizar que estos principios deben ser respetados no solo dentro del desarrollo de un proceso como tal, sino también desde otras esferas, considerando que la dignidad humana es de rango constitucional, es a su vez "la cualidad esencial del ser humano, su cualidad específica y exclusiva, en virtud de la cual se distingue lo humano de lo no-humano (...), la dignidad se muestra como una categoría pluridisciplinar y pluridimensional”. (Marín Castán, 2007, pág. 1). Menciona la autora que es pluridisciplinaria porque confluyen varias disciplinas entre ellas la filosofía general, y en particular su rama de ética o filosofía moral, la Antropología, la política y el derecho y pluridimensional, porque ofrece categorías de la (i) dimensión religiosa, (ii) dimensión ontológica, (iii) dimensión ética y (iv) dimensión social. De igual forma el principio de la dignidad humana es definido como "La dignidad es una atribución propia de todo ser humano, no en tanto que individuo de la especie humana, sino en tanto que miembro de la comunidad de seres morales. La dignidad es una instancia moral que distingue al ser humano de los animales" (Michelini, 2010, pág. 43). Por tanto y atendiendo

\footnotetext{
${ }^{24}$ Ley 1476 de 2011 "Por la cual se expide el régimen de responsabilidad administrativa por perdida o daño de bienes de propiedad del Ministerio de Defensa Nacional sus entidades adscritas o vinculadas a la fuerza pública" ${ }^{25}$ Véase los principios de la Ley 1476 de 2011
} 
a esa lógica, toda persona tiene el derecho a contar con unos plazos razonables que le permitan materializar los otros principios como el debido proceso y el derecho a la defensa, permitiendo así un ejercicio sano y acorde con las disposiciones constitucionales, precisamente el respeto se debe por el solo hecho de ser personas, lo cual nos implica un trato digno y respetuoso al servidor que se encuentre inmerso en una investigación administrativa adelantada en el escenario de las instituciones que conforman el ramo de la defensa nacional.

Atendiendo aún la generalidad del asunto, la investigación nos conduce a referenciar y analizar la exposición de motivos elaborada por el Ministro de la Defensa de la época doctor Gabriel Silva Lujan, la cual dio como resultado la expedición de la Ley 1476 de 2011, resaltando la importancia de contar con una norma propia para los miembros de la fuerza pública, considerando la lógica misma del régimen de carrera especial que establece normas exclusiva en materia disciplinaria, penal militar y prestacional. Dicha exposición de motivos, comienza citando al maestro Fernando Hinestrosa en el prólogo al libro ¿El daño? De Juan Carlos Henao, donde se pone de presente que la vida de relación con las personas conlleva un doble permanente riesgo, el de dañar y ser dañados, y concluye manifestando que el daño es un fenómeno inherente al ser humano. Argumenta de igual forma la mencionada exposición de motivos que el servidor público debe responder por los daños o pérdidas que se causen a bienes del Estado, ello en tratándose de la responsabilidad administrativa. Asimismo indica de manera breve en línea de tiempo, las normas que han existido de la responsabilidad administrativa, iniciando con el decreto número 1255 de 1961, el primero que consagró los procesos administrativos por pérdidas o daños de material de guerra, dicha norma fue reformada por el decreto 791 del 5 de abril de 1979 y sufrió unas modificaciones en el año 2000 con el decreto número 1932 en lo que respecta a temas de competencia y cuantía, vale la pena mencionar que el decreto 791 de 1979, se mantuvo vigente hasta la 
expedición de la Ley 1476 de 2011. De igual manera el proponente de la norma, hace una diferencia significativa de la responsabilidad administrativa y la responsabilidad fiscal, donde se puede colegir que la responsabilidad administrativa abarca todo servidor público que ocasione daños o pérdida a bienes del Estado, por su parte la responsabilidad fiscal evalúa la legalidad del gasto y sus aspectos financieros, en tanto que en la responsabilidad fiscal el daño debe resarcirse y en la responsabilidad administrativa el servidor público está obligado a reponer o pagar el bien perdido o dañado. (Véase en el anexo \# 1 la exposición de motivos de la Ley 1476 de 2011 del doctor Gabriel Silva Luján, Ministro de Defensa de la época del 23 de julio del año 2010). Sin embargo mencionada exposición de motivos conforme el criterio que se expresa, se queda corta, toda vez que no realizó un análisis cuidadoso de los procedimientos que la misma norma incluye, dentro de ellos el procedimiento abreviado objeto de estudio, habida cuenta que se concentró más en efectuar una presentación histórica de los motivos por los cuales se requiere una ley que regule la pérdida y los daños que se les causen a los bienes de propiedad del ramo de la defensa nacional, y no se abordó una motivación clara de los temas que esta ley en la actualidad abarca dentro de los cuales se encuentra el procedimiento abreviado, a través del cual se establece que cuando la cuantía del bien perdido o dañado sea inferior a dos (2) salarios mínimos legales mensuales vigentes, se debe tramitar una investigación administrativa de carácter abreviada en tan sólo ocho (8) días, donde se deberán escuchar al investigado en descargos, realizar práctica de pruebas y proceder el funcionario competente a dictar una decisión respecto de los hechos que le fueron puestos en conocimiento. Considerando lo anterior, no se podría hasta este momento partir de la motivación que origino la aprobación por parte del legislador de la Ley 1476 de 2011, toda vez que precisamente no fue establecido, es decir no se establecen los fundamentos claros que expliquen la necesidad de contar con un procedimiento abreviado dentro del escenario 
administrativo de la fuerza pública, como tampoco saber el por qué se establecieron tan solo ocho (8) días para tramitarlo, lo que per se, nos colocaría en un escenario oscuro que genera varias dudas sobre el particular, entre ellas saber (i) $i$ los tiempos establecidos en anotado artículo vulnera el debido proceso relacionado con el derecho a la defensa? (ii) ¿Cuál sería el plazo razonable para adelantar la investigación de carácter abreviada que nos trae la precitada Ley? (iii) de llegar a vulnerar el derecho a la defensa del investigado ¿Cuál sería la alternativa más adecuada que nos permita garantizar principios y derechos, partiendo de la dignidad humana?, todos estos interrogantes se tratarán de esclarecer a través del análisis de la jurisprudencia, la doctrina y el análisis de casos desde el punto de vista temático, doctrinal, jurídico, práctico y casuístico.

Asimismo la precitada Ley, ha tenido dos (2) demandas de varios artículos ante la Corte Constitucional, entre esas se encuentra la sentencia C-633 de $2012^{26}$, en la cual se demandó la inconstitucionalidad del contenido del artículo 35 de la Ley 1476 de 2011, alegando violación de los principios de legalidad y debido proceso, de igual forma la sentencia C-136 de $2016^{27}$, en la que se demandó la inconstitucionalidad contra el artículo 59 (parcial) de la norma en mención, alegando la vulneración de los principios de publicidad, contradicción y debido proceso, para este caso la Corte, decidió declarar la inexequilidad del contenido normativo demandado, al considerar que no supero el examen del test de proporcionalidad de la Corte, toda vez que la medida decretada por el legislador es desproporcionada en sentido estricto. Por lo tanto es violatoria del principio de publicidad, defensa y debido proceso.

Una vez expuesta la generalidad del tema que se aborda se presentará la descripción especifica del procedimiento abreviado regulado por el artículo 94 de la ley 1476 de 2011, el

\footnotetext{
${ }^{26}$ Corte Constitucional. Sentencia C-633 de 2012. M.P. MAURICIO GONZÁLEZ CUERVO

${ }^{27}$ Corte Constitucional. Sentencia C-136-2016. MP. LUIS ERNESTO VARGAS SILVA
} 
cual codifica su procedimiento de la siguiente manera: el funcionario con competencia administrativa escucha en diligencia de descargos al presunto responsable de la pérdida o el daño del bien de propiedad del Ministerio de Defensa Nacional o sus entidades adscritas o vinculadas a la fuerza pública, en dicha diligencia se cita al funcionario implicado en compañía opcional de un abogado y se le indaga sobre la pérdida o daño del bien puesto bajo su responsabilidad, el funcionario implicado tiene la posibilidad de ser escuchado y presentar pruebas y controvertir aquellas que se presenten en su contra, de igual forma se le brinda la opción de reponer o reparar el bien perdido o dañado cuando exista allanamiento a los cargos indilgados. De igual forma establece la disposición en mención que la administración en cabeza del funcionario competente en el plazo de cinco (5) días deberá disponer del recaudo de pruebas que se requieran en el caso bajo litigio (sub lite) y proferirá fallo escrito y motivado de única instancia dentro de los tres días hábiles siguientes, contra el cual, el funcionario implicado tiene la posibilidad de recurrir la decisión de la administración si la considera contraria a sus intereses o aceptarla y proceder al pago o reposición del bien.

Como se observa esta disposición legal, establece términos procesales muy cortos, toda vez que tan solo en ocho (8) días la administración cuenta con el plazo para resolver una situación que atañe contextos laborales de personas que hacen parte del ramo de la defensa nacional del país, es decir que desde el punto de vista considerativo, esta norma vulnera el derecho a la defensa del investigado, toda vez que no le brinda la posibilidad al funcionario investigado de realizar o ejercer una efectiva defensa de sus derechos, sino por el contrario como una disposición arbitraria le impone al funcionario de la administración competente la labor en tiempos excesivamente breves, de tomar decisiones que pueden llegar a afectar los intereses de los investigados. Ello sin mencionar que dicha norma no le brinda la posibilidad al funcionario investigado en el eventual caso de apelar la decisión, es decir este 
procedimiento denominado abreviado no permite el recurso de alzada conocido en los escenarios jurídicos como doble instancia.

Una vez descrito el procedimiento abreviado que establece la ley 1476 de 2011, por medio de la cual se adelantan investigaciones por pérdida o daño de bienes de propiedad del ramo de la defensa nacional, se presentará a continuación (apartado B) la descripción del procedimiento abreviado en otras áreas como la disciplinaria y la penal militar, con el propósito de realizar un ejercicio de comparación, el cual ayudará a tomar una posición en la dicotomía planteada. Se hace la observación que se relacionan las áreas del derecho anteriormente mencionados, teniendo en cuenta que atañen contextos laborales similares, toda vez que en ellas se investigan de igual forma a servidores públicos de las Fuerzas Armadas.

\section{B. Análisis del procedimiento abreviado desde otras áreas: disciplinaria ley 1015 de 2006 y Procedimiento verbal de responsabilidad fiscal. Ley 1474 de 2011}

Para empezar en este apartado se tomará como ejemplo dos procedimientos jurídicos: la disciplinaria y la fiscal, las cuales desarrollan procedimientos abreviados distintos, con el propósito de describir la estructura que emplea cada una de ellas en cuanto a términos procesales, pasos, formas y garantías referidas al debido proceso, lo cual permitirá efectuar un cuadro comparativo entre el procedimiento abreviado regulado por la ley 1476 de 2011 y las áreas planteadas, obteniendo insumos informativos importantes en el tema de estudio, que

permitirá ayudar a resolver el problema jurídico planteado. En ese orden de ideas, se hará referencia en primera medida al procedimiento abreviado que se aplica en la parte disciplinaria, haciendo claridad que la Policía Nacional de Colombia, se rige en el aspecto 
Disciplinario por la Ley 1015 de $2006^{28}$, no obstante en el escenario procedimental en la que se estructura el actuar disciplinario de la institución, el mismo se rige en el marco de la Ley 734 de $2002^{29}$, dicha norma en su contenido contempla dos tipos o clases de procedimientos: (i) el verbal sumario y (ii) el procedimiento ordinario. Por consiguiente se referenciará en el análisis el primero de ellos anotada, toda vez que es aquel que guarda características similares con el procedimiento abreviado de la Ley 1476 de 2011.

El titulo XI de la Ley 734 de 2002, establece los procedimientos especiales, desarrollado en su Capítulo I, el procedimiento verbal ${ }^{30}$, en el escenario de ocho artículos, los cuales

\footnotetext{
${ }^{28}$ L EY 1015 DE 2006. Por medio de la cual se expide el Régimen Disciplinario para la Policía Nacional.

${ }^{29}$ Ley 734 de 2002. Por la cual se expide el Código Disciplinario Único

${ }_{30}$ Artículo 175. Aplicación del procedimiento verbal. El procedimiento verbal se adelantará contra los servidores públicos en los casos en que el sujeto disciplinable sea sorprendido en el momento de la comisión de la falta o con elementos, efectos o instrumentos que provengan de la ejecución de la conducta, cuando haya confesión y en todo caso cuando la falta sea leve.

También se aplicará el procedimiento verbal para las faltas gravísimas contempladas en el artículo 48 numerales $2,4,17,18,19,20,21,22,23,32,33,35,36,39,46,47,48,52,54,55,56,57,58,59$ y 62 de esta ley. Inciso declarado EXEQUIBLE por la Corte Constitucional mediante Sentencia C-1076 de 2002.

En todo caso, y cualquiera que fuere el sujeto disciplinable, si al momento de valorar sobre la decisión de apertura de investigación estuvieren dados los requisitos sustanciales para proferir pliego de cargos se citará a audiencia. Inciso declarado EXEQUIBLE por la Corte Constitucional mediante Sentencia C-242 de 2010

El Procurador General de la Nación, buscando siempre avanzar hacia la aplicación de un procedimiento que desarrolle los principios de oralidad y concentración, podrá determinar otros eventos de aplicación del procedimiento verbal siguiendo los derroteros anteriores. Texto subrayado declarado INEXEQUIBLE por la Corte Constitucional mediante Sentencia C-1076 de 2002; Ver la Sentencia de la Corte Constitucional C-1077 de 2002.

Artículo 175A. Adicionado por el art. 24, Decreto Nacional 126 de 2010

Artículo 176. Competencia. En todos los casos anteriores son competentes para la aplicación del procedimiento verbal, la oficina de control interno disciplinario de la dependencia en que labore el servidor público autor de la falta disciplinaria, la Procuraduría General de la Nación y las personerías municipales y distritales.

Cuando el procedimiento verbal se aplique por las oficinas de control interno se deberá informar de manera inmediata, por el medio más eficaz, al funcionario competente de la Procuraduría General de la Nación o personerías distritales o municipales según la competencia.

Artículo 177. Audiencia. Modificado por el art. 58, Ley 1474 de 2011. Calificado el procedimiento a aplicar conforme a las normas anteriores, el funcionario competente citará a audiencia al posible responsable, para que dentro del término improrrogable de dos días rinda versión verbal o escrita sobre las circunstancias de su comisión. Contra esta decisión no procede recurso alguno.

En el curso de la audiencia, el investigado podrá aportar y solicitar pruebas, las cuales serán practicadas en la misma diligencia, dentro del término improrrogable de tres días, si fueren conducentes y pertinentes. Si no fuere posible hacerlo se suspenderá la audiencia por el término máximo de cinco días y se señalará fecha para la práctica de la prueba o pruebas pendientes.

De la audiencia se levantará acta en la que se consignará sucintamente lo ocurrido en ella.

Ver la Sentencia de la Corte Constitucional C-1076 de 2002.
} 
establecen: (i) aplicación, (ii) competencia, (iii) audiencia, (iv) decisión, (v) ejecutoria, (vi) recursos y (vii) remisión al procedimiento ordinario. Este procedimiento ha sido modificado por la Ley 1474 de $2011^{31}$, en lo que respecta a la aplicación establecida en el artículo 175 de la Ley 734 de 2002, de igual forma el artículo 177 y el artículo $180^{32}$ de la misma norma. Las modificaciones realizadas por el Estatuto Anticorrupción, están encaminadas a darle una mejor estructura al procedimiento como tal en cuanto a su aplicación y desarrollo, es decir, establece un derrotero que los funcionarios con competencia disciplinaria deben adelantar conforme el principio de legalidad. Allí se contempla un escenario en el cual el investigado puede presentar sus descargos ante el juez disciplinario, así como desplegar la práctica y controversia de pruebas y presentar alegatos de conclusión previa el fallo. Todo lo anterior conforme la norma en mención, se realiza en treinta y tres (33) días, los cuales se pueden ampliar dependiendo la complejidad que cada investigación guarde.

Llegados a este punto se observa, que las modificaciones realizadas por la Ley 1474 de 2011, apuntan en una sola perspectiva, la cual es desarrollada a su vez por el Código Disciplinario Único, que consiste en aplicar un procedimiento disciplinario que guarde las

Artículo 178. Adopción de la decisión. Concluidas las intervenciones se procederá verbal y motivadamente a emitir el fallo. La diligencia se podrá suspender, para proferir la decisión dentro de los dos días siguientes. Los términos señalados en el procedimiento ordinario para la segunda instancia, en el verbal, se reducirán a la mitad. Artículo 179. Ejecutoria de la decisión. La decisión final se entenderá notificada en estrados y quedará ejecutoriada a la terminación de la misma, si no fuere recurrida.

Artículo 180. Recursos. Modificado por el art. 59, Ley 1474 de 2011. Contra el fallo proferido en audiencia sólo procede el recurso de apelación, que se interpondrá en la misma diligencia y se sustentará verbalmente o por escrito dentro de los dos días siguientes y será decidido dos días después por el respectivo superior. Procede el recurso de reposición cuando el procedimiento sea de única instancia, el cual deberá interponerse y sustentarse una vez se produzca la notificación por estrado, agotado lo cual se decidirá el mismo. Texto subrayado declarado EXEQUIBLE por la Corte Constitucional mediante Sentencia C-763 de 2009

Artículo 181. Remisión al procedimiento ordinario. Los aspectos no regulados en este procedimiento se regirán por lo dispuesto en el siguiente y por lo señalado en el procedimiento ordinario, siempre y cuando no afecte su naturaleza especial.

${ }^{31}$ Ley 1474 de 2011. Por la cual se dictan normas orientadas a fortalecer los mecanismos de prevención, investigación y sanción de actos de corrupción y la efectividad del control de la gestión pública. 
garantías referidas al debido proceso Constitucional, toda vez que permite el ejercicio del derecho de defensa tanto técnica como material. De donde se infiere una razonabilidad en la aplicación de los tiempos establecidos para cada actuación, habida cuenta que el contexto dado permite a la defensa, presentar pruebas y controvertir las mismas, allegar alegatos de conclusión e interponer recursos, todo en unos tiempos razonables y adecuados conforme el criterio expuesto. Por el contrario, el artículo 94 de la Ley 1476 de 2011, que establece el procedimiento abreviado, no guarda una razonabilidad en el marco de sus actuaciones, toda vez que no brinda aspectos importantes como la presentación de recursos ante la práctica de pruebas, ni tampoco la posibilidad de presentar alegatos de conclusión una vez concluida la etapa probatoria.

En segundo lugar se abordará el procedimiento verbal de responsabilidad fiscal, consagrado en el artículo 98 de la ley 1474 de 2011, el cual contempla varias etapas en la que se desarrolla el mismo. No obstante, se realizará un breve preámbulo para establecer su objeto y definir su naturaleza jurídica, en ese orden de ideas, el proceso de responsabilidad fiscal, tiene por objeto resarcir el patrimonio público del Estado, cuando por la gestión irregular del gestor fiscal se vea lesionado dicho patrimonio, bien sea por dolo o culpa de quien tiene la responsabilidad legal de administrarlo de forma debida, el Estado a través de sus herramientas legales adelantará las investigaciones correspondientes, con el fin o propósito de resarcir tal afectación patrimonial. El proceso de responsabilidad fiscal, se encuentra consagrado en el artículo $1^{\circ}$ de la ley 610 de $2000^{33}$ que a la letra dice:

"El proceso de responsabilidad fiscal es el conjunto de actuaciones administrativas adelantadas por las Contralorías con el fin de determinar y establecer la responsabilidad de los servidores públicos y de los particulares, cuando en el ejercicio de la gestión fiscal o con ocasión de ésta, causen por acción u omisión y en forma dolosa o culposa un daño al patrimonio del Estado".

33 Ley 610 de 2000 "Por la cual se establece el trámite de los procesos de responsabilidad fiscal de competencia de las contralorías". 
Establece la norma en comento que cuando se encuentre objetivamente establecida la existencia del daño patrimonial al Estado y exista prueba que comprometa la responsabilidad del gestor fiscal, el funcionario con competencia administrativa, expedirá auto de apertura e imputación de responsabilidad fiscal, mediante el cual se indique el lugar, fecha y hora para dar inicio a la audiencia de descargos.

De igual forma el proceso de responsabilidad fiscal se desarrollará en dos (2) audiencias públicas, la primera denominada de descargos y la segunda de decisión, dichas audiencias deberán estar presididas por el funcionario con competencia administrativa o por algún funcionario designado.

Las etapas del proceso de responsabilidad fiscal comprenden las audiencias de descargos y decisión con sus respectivos trámites ${ }^{34}$, donde se puede evidenciar que se respetan las garantías procesales del ejercicio del derecho de defensa y contradicción. Estas etapas como las que se desarrollan en otras jurisdicciones, traen consigo sus respectivas reglas ${ }^{35}$, las cuales

34 ARTÍCULO 99. AUDIENCIA DE DESCARGOS. La Audiencia de Descargos deberá iniciarse en la fecha y hora determinada en el auto de apertura e imputación del proceso. La audiencia de descargos tiene como finalidad que los sujetos procesales, puedan intervenir con todas las garantías procesales y que se realicen las siguientes actuaciones:

1. Ejercer el derecho de defensa.

2. Presentar descargos a la imputación.

3. Rendir versión libre.

4. Aceptar los cargos y proponer el resarcimiento del daño o la celebración de un acuerdo de pago.

5. Notificar medidas cautelares.

6. Interponer recurso de reposición.

7. Aportar y solicitar pruebas.

8. Decretar o denegar la práctica de pruebas.

9. Declarar, aceptar o denegar impedimentos.

10. Formular recusaciones.

11. Interponer y resolver nulidades.

12. Vincular nuevo presunto responsable.

13. Decidir acumulación de actuaciones.

14. Decidir cualquier otra actuación conducente y pertinente.

${ }^{35}$ ARTÍCULO 101. TRÁMITE DE LA AUDIENCIA DE DECISIÓN. La audiencia de decisión se tramitará conforme a las siguientes reglas:

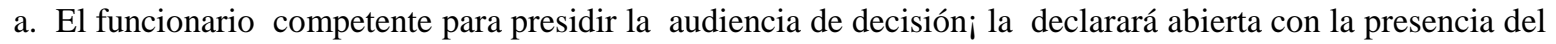
funcionario investigador fiscal, los profesionales técnicos de, apoyo designados, el presunto responsable fiscal 
son desarrolladas por parte de los funcionarios que intervienen en el proceso y que tienen la potestad legal de adelantar estos trámites. La ley 1474 de 2011 que desarrolla el procedimiento verbal de responsabilidad fiscal, contempla todas las garantías referidas al debido proceso constitucional, en atención a que el desarrollo de tal procedimiento así lo demuestra. En lo que respecta a los tiempos para el desarrollo de las audiencias, tanto de descargos como de decisión, y trámites previos, se observan plazos adecuados toda vez que el proceso se puede suspender por práctica de pruebas hasta por un (1) año, de igual forma si en el desarrollo de las audiencias mencionadas, se logra justificar alguna suspensión de las mismas, el funcionario con competencia administrativa así lo decretará.

El proceso verbal de responsabilidad fiscal a diferencia del procedimiento abreviado de la Ley 1476 de 2011, en lo que respecta a los tiempos del desarrollo de las etapas procesales, consagran unos tiempos, que se pueden considerar mucho más flexibles, permitiendo a los operadores jurídicos que desarrollan el proceso y al mismo investigado asumir sus roles con un mejor manejo del tiempo, lo cual impacta positivamente en la actividad que se realiza conforme los parámetros que la ley 1474 de 2011 establece.

o su apoderado, si lo tuviere, o el defensor de oficio y el garante o a quien se haya designado para su representación.

b. Se concederá el uso de la palabra a los sujetos procesales para que expongan sus alegatos de conclusión sobre los hechos que fueron objeto de imputación.

c. El funcionario realizará una exposición amplia de los hechos, pruebas, defensa, alegatos de conclusión, determinará si existen pruebas que conduzcan a la certeza de la existencia o no del daño al patrimonio público; de su cuantificación; de la individualización y actuación del gestor fiscal a título de dolo o culpa grave; de la relación de causalidad entre la conducta del presunto responsable fiscal y el daño ocasionado, y determinará también si surge una obligación de pagar una suma liquida de dinero por concepto de resarcimiento.

d. Terminadas las intervenciones el funcionario competente declarará que el debate ha culminado, y proferirá en la misma audiencia de manera motivada, fallo con o sin responsabilidad fiscal. Para tal efecto, la audiencia se podrá suspender por un término máximo de veinte (20) días, al cabo de los cuales la reanudará y se procederá a dictar el fallo correspondiente, el cual se notificará en estrados. El responsable fiscal, su defensor, apoderado de oficio o el tercero declarado civilmente responsable, deberán manifestar en la audiencia si interponen recurso de reposición o apelación según fuere procedente, caso en el cual lo sustentará dentro de los diez (10) días siguientes.

e. La cuantía del fallo con responsabilidad fiscal será indexada a la fecha de la decisión. La providencia final se entenderá notificada en estrados en la audiencia, con independencia de si el presunto responsable o su apoderado asisten o no a la misma. 
Por consiguiente el escenario jurídico en el cual se desarrolle un procedimiento, debe ser aquel que no conlleve entramados oscuros o perjudiciales para el investigado, por el contrario, el procedimiento conforme lo establece la norma Superior, es aquel que es claro para el investigado, donde además se le brinden oportunidades conforme se van tomando decisiones en el desarrollo de la contienda jurídica, dando las posibilidades de ejercer una defensa adecuado, conociendo del hecho que se le investiga, para así poder presentar y controvertir las pruebas que le sean allegadas en su contra, asimismo presentar las que le sean favorables, oponerse a las decisiones que le desfavorezcan a través de los recursos de ley y presentar alegatos de conclusión del respectivo proceso. En suma el proceso ideal sería aquel que sea público, transparente, sin dilaciones injustificadas, imparcial y que respete literalmente las garantías referidas al debido proceso constitucional.

El procedimiento abreviado de la ley 1476 de 2011, es un procedimiento que al igual de las jurisdicciones disciplinaria y fiscal, conforme lo estudiado en líneas anteriores, debe respetar las garantías procesales mencionadas, y tanto el legislador como los operadores jurídicos, le deben de prestar la debida importancia. Uno de los argumentos a tener en cuenta para regular normativamente un procedimiento, es su naturaleza, es decir, para que se crea, situación que el legislador no debe dejar pasar por alto.

Pasando a otro escenario, se analizará los factores económicos que guarda el procedimiento abreviado, con el propósito de conocer varios aspectos importantes para la investigación que se adelanta, para lo cual se interrogará: (i) si es necesario que el Estado investigue aspectos de "menores o de poca importancia" mediante procedimientos abreviados o cortos, (ii) uno de los requisitos para adelantar la investigación del procedimiento abreviado de la Ley 1476 de 2011 es la cuantía del bien, la cual no puede ser superior a dos (2) salarios mínimos legales mensuales vigentes, en tal sentido, ¿es viable que 
el Estado tramite esta clase de investigaciones, a pesar de sus costos?, y que pasaría si el Estado no decide investigar, dado que le resulta mucho más costoso adelantar procesos administrativos de carácter abreviados, que el valor de los bienes perdidos o dañados por los funcionarios pertenecientes al ramo de la defensa nacional que le son asignados dichos bienes para el ejercicio de sus funciones. Por tanto se hace necesario dedicar una sección exclusivamente al análisis de esta clase de factores, toda vez que ello va a permitir establecer la importancia de dicho procedimiento y su incidencia en las entidades que los regulan.

\section{SECCIÓN 2. LOS EFECTOS ECONÓMICOS EN LA APLICACIÓN DEL PROCEDIMIENTO ABREVIADO DESDE LA ÓPTICA DE LA ADMINISTRACIÓN}

Uno de los aspectos importantes que gira en torno al procedimiento abreviado regulado por la Ley 1476 de 2011, es sin duda alguna el económico, el cual será analizado en esta sección desde la perspectiva del coste de oportunidad, en aras de establecer la toma de decisiones en esta clase de escenarios, en tal sentido, incidentalmente el procedimiento al que nos referimos está determinada por la pérdida o daño de un bien, el cual a su vez como condicionante normativo debe ser de propiedad del ramo de la defensa nacional. Otro aspecto importante a tratar en este apartado, está relacionado con las entidades vinculadas o adscritas al ramo de la Defensa Nacional que conforme la norma antes anotada, tienen la facultad de adelantar investigaciones en contra de sus propios funcionarios y de particulares cuando así se establezca. Por tanto se hace necesario analizar desde una perspectiva en particular la cantidad de investigaciones que se adelantan por año en el escenario administrativo, precisando el valor monetario de los bienes determinados en cada investigación y comparar los costos que implica para el Estado, desde el punto de vista de la oportunidad, de 
funcionarios y logística necesaria, de cara a impartir justicia desde la óptica del procedimiento abreviado del artículo 94 de la Ley 1476 de 2011.

\section{A. Factores económicos que inciden en la activación del procedimiento abreviado}

Es importante y a la vez necesario indicar previo al desarrollo comparativo desde el punto de vista del valor monetario del trámite de investigaciones administrativas por pérdida o daño de bienes pertenecientes al ramo de la Defensa nacional, qué bienes son más comunes encontrar en las investigaciones de carácter abreviadas, expuestos a sufrir pérdida o daño. En ese orden de ideas, los bienes según el análisis a presentar en dichas investigaciones son los siguientes: brújulas, con un valor monetario aproximado de noventa y ocho mil pesos (\$98.000), placas de identificación policial, con un valor monetario aproximado de ciento tres mil pesos (\$103.000), esposas policiales, con un valor monetario de doscientos setenta y nueve mil trescientos cincuenta y cuatro pesos $(\$ 279.354$.) proveedores de pistola y fusil, con un valor monetario aproximado de doscientos cincuenta y seis mil pesos $(\$ 256.000)$, cañón pistola y fusil, con un valor monetario aproximado de trescientos sesenta y un mil pesos $(\$ 361.000)$, binoculares, con un valor monetario aproximado de un millón noventa y cinco mil trescientos setenta y ocho pesos (\$1.095.378) casco balístico nivel IIIA, con un valor monetario de un millón doscientos dieciséis mil seiscientos catorce mil pesos (\$1.216.614), portafusil con un valor monetario de sesenta y cuatro mil pesos $(\$ 64.000)$, cartuchos calibre 5.56, con un valor monetario por unidad de mil trecientos setenta y ocho pesos con ochenta y seis centavos $(\$ 1.378 .86)$, entre otros elementos. Es preciso aclarar que el procedimiento abreviado se aplica sobre aquellos bienes que no superen en pesos Colombianos dos salarios mínimos legales mensuales vigentes. Asimismo existen otros 
bienes accesorio, es decir que hacen parte de uno principal, ejemplo de lo anterior se encuentran los panorámicos y accesorios de los vehículos, al igual que los accesorios de las motocicletas entre otros bienes que por su valor no llegan a superar los dos (2) salarios mínimos legales mensuales vigentes. No obstante, si el bien perdido o dañado llega a superar los dos (2) smlmv, el procedimiento a seguir de conformidad con la Ley 1476 de 2011 es el procedimiento ordinario, el cual establece unos términos procesales y parámetros distintos al procedimiento abreviado, que no se mencionarán, toda vez que no es el objeto del presente estudio.

Presentado lo anterior, se hace necesario analizar el valor monetario de los bienes objeto de investigaciones administrativas abreviadas por pérdida o daño, así como la cantidad de funcionarios que intervienen en la tramitación de las mismas, bien sea de forma exclusiva o no y el costo que implica para el Estado poner en marcha la aplicación del artículo 94 de la Ley 1476 de 2011, en los escenarios administrativos, por tal razón se referenciará información del Departamento de Policía Arauca, Oficina de Asuntos Jurídicos mediante solicitud realizada, la cual esta discriminada de la siguiente forma:

Es preciso mencionar que la solicitud elevada a la entidad antes mencionada, estuvo encaminada a conocer de primera mano el valor monetario que conlleva adelantar un procedimiento abreviado en el marco de la Ley 1476 de 2011, tales como: conocer la cantidad de investigaciones tramitadas por el competente entre los años de 2015 y 2016, pago de funcionarios, gastos de papelería, impresión de documentos, utilización de computadores y consumo de servicios públicos. En ese orden de las ideas, la competencia para adelantar actuaciones por pérdida o daño de bienes, está establecido por la cuantía conforme lo indica 
el artículo 21 de la Ley 1476 de $2011^{36}$. Donde se expresa que las autoridades para tomar decisiones en los procesos administrativos son determinados por la cuantía, en tal sentido para que se adelante un procedimiento administrativo abreviado, la pérdida o el daño debe ser inferior a dos (2 smlmv), conforme lo establece la norma en mención, correspondiéndole de igual forma la competencia para fallar a los Jefes de dependencias administrativas donde se encuentre en inventario el bien objeto de investigación por pérdida o daño, dicho funcionario no tiene dedicación exclusiva en la tramitación de esta clase de investigaciones, sin embargo dicha norma, le otorga la facultad de tomar decisiones al respecto.

De igual forma el artículo 46 de la Ley 1476 de 2011, establece que el cargo de secretario será de dedicación exclusiva en la tramitación de investigaciones administrativas por pérdida o daño de bienes de propiedad del ramo de la defensa nacional, para lo cual podrán ser designados Oficiales, miembros del nivel ejecutivo, suboficiales y personal civil en servicio activo del Ministerio de Defensa Nacional, sus entidades adscritas o vinculadas a la fuerza pública. Estableciendo además que dicho cargo es de forzosa aceptación, es decir que no puede ser rechazada la asignación por el funcionario perteneciente alguna de las entidades antes descritas. Asimismo el artículo $47^{37}$ de la anotada Ley, fija las competencias al secretario.

36 “ARTÍCULO 21. COMPETENCIA POR LA CUANTÍA. Determínense las siguientes autoridades para fallar los procesos administrativos:

1. Inferior a dos (2) smlmv. En el Ministerio de Defensa Nacional, en las entidades adscritas o vinculadas al Ministerio de Defensa Nacional, en la Dirección General Marítima, en el Comando General de las Fuerzas Militares, en los Comandos de Fuerza, en las Unidades Militares y en la Policía Nacional, conocerán y fallarán en única instancia, el Jefe de la respectiva dependencia administrativa, militar o policial donde se encuentre en inventario el bien. (...). (Negrillas fuera de texto).

${ }^{37}$ ARTÍCULO 47. FUNCIONES Y DEBERES. Son funciones y deberes del Secretario las siguientes:

1. Asistir al Funcionario de Instrucción en las diferentes diligencias realizadas dentro de la investigación administrativa.

2. Foliar y organizar en forma cronológica y consecutiva el expediente.

3. Guardar la debida reserva sumarial.

4. Ejercer la custodia y cuidado del expediente. 
Respectivamente el artículo $48^{38}$ de la normativa descrita con anterioridad, asigna responsabilidades al Asesor Jurídico, quien de igual forma interviene en la investigación administrativa abreviada, asesorando jurídicamente en todo momento el proceso, cuyas funciones están encaminadas a garantizar el cumplimiento del principio de legalidad, debido proceso y la debida radicación de los asuntos de conocimiento de los funcionarios competentes.

Los funcionarios mencionados con anterioridad son aquellos que la Ley 1476 de 2011 determina como responsables directos de adelantar el procedimiento abreviado, asignándoles a cada uno marcos de actuación dentro del contexto administrativo de manera individual, no obstante la mencionada Ley incluye o establece de igual forma responsabilidades a otros funcionarios, los cuales pueden ser nombrados por los competentes o funcionarios de instrucción, que si bien es cierto no tienen una representación protagónica en el desarrollo de la investigación, su papel es de vital importancia en aras de garantizar el cumplimiento del debido proceso. Los mencionados funcionarios son los peritos que se encuentran regulados por el artículo 79 de la norma citada, los cuales de conformidad con la Ley son auxiliares de la investigación administrativa y son designados por sus conocimientos, técnicos, científicos, artísticos u otros campos del saber, con el objetivo o propósito de apoyar la labor de instrucción en el esclarecimiento de los hechos. Establece la norma que el cargo de perito es

5. Legajar en cuadernos separados la documentación de carácter reservado.

6. Realizar las citaciones, comunicaciones, constancias y notificaciones que se requieran.

7. Expedir las copias del expediente que hayan sido autorizadas.

8. Facilitar el acceso del expediente a los sujetos procesales cuando así lo requieran.

9. Mantener el cuaderno de copias con el mismo contenido y folios del original.

${ }^{38}$ ARTÍCULO 48. ASESOR JURÍDICO. Las funciones del asesor jurídico son las siguientes:

1. Brindar asesoría en todas las etapas del proceso administrativo.

2. Dar estricto cumplimiento a los términos de instrucción.

3. Velar por el cumplimiento de los términos de instrucción.

4. Controlar que se lleven de manera adecuada los libros radicadores o bases de datos actualizados.

5. Verificar el adecuado archivo de los expedientes." 
de forzosa aceptación al igual que la del secretario, salvo las excepciones legales, es decir que están obligados por la Ley a emitir sus conceptos en el campo del conocimiento que dominan, sin emitir juicios de responsabilidad, para lo cual solo podrá ser designado uno por cada materia según el caso sin importar la cuantía del bien perdido o dañado. (Véase deberes de los peritos artículo 80 ley 1476 de 2011$)^{39}$.

Una vez puesto de presente las distintas funciones y deberes conforme lo establece la normativa antes descrita, les asiste a los funcionarios encargados de adelantar procesos administrativos por pérdida o daño de bienes de propiedad o al servicio del ramo de la defensa nacional. Con el fin de realizar la aproximación a los costos de este tipo de procesos se acudió a la oficina jurídica del Departamento de Policía Arauca, con el propósito de conocer el valor monetario que conlleva la tramitación de esta clase de procesos, en lo que respecta al pago de funcionarios. (Véase tabla \#3).

Con base en la información plasmada con anterioridad, es preciso aclarar que los valores económicos constituyen el salario total devengado mensual y el total devengado por año laboral, de los funcionarios con dedicación exclusiva que intervienen en las investigaciones administrativas abreviadas por perdida o daño de bienes, de conformidad con las facultades otorgadas por la Ley 1476 de 2011, como lo es el asesor jurídico y sustanciador de procesos administrativos por pérdida o daño de bienes del ramo de la defensa nacional, no obstante algunos funcionarios entre los que se encuentran en particular jefes de dependencias administrativas donde se encuentras inventariados los bienes y los peritos, no son de

\footnotetext{
${ }^{39}$ Artículo 80. Deberes del perito. Son deberes del perito los siguientes:

1. Rendir el dictamen dentro de los términos señalados por el funcionario que lo designó.

2. Obrar de forma imparcial.

3. Guardar la respectiva reserva sumarial.

4. Ejercer la custodia e integridad del expediente.

5. Aclarar, completar o ampliar el dictamen cuando sea requerido por el funcionario competente.
} 
dedicación exclusiva en los tramites que se mencionan, motivo por el cual no se tuvo en cuenta el salario que devengan. Asimismo se verá, desde una tabla, la información en lo que respecta a la cantidad de casos ingresados mes a mes en los años 2015 y 2016 por la figura del procedimiento abreviado, y el promedio en pesos de un salario mínimo legal mensual de la vigencia anterior, comparado el valor monetario que acarreo la administración (Departamento de Policía Arauca), en lo atinente a pago de funcionarios con dedicación exclusiva en la tramitación de procedimientos abreviados y otros gastos que conlleva la operación.

Investigaciones administrativas abreviadas por pérdida o daño de bienes de propiedad del Ministerio de Defensa Nacional sus Entidades Adscritas o Vinculadas a la Fuerza Pública, Ley 1476 de 2011-Departamento de Policía Arauca

Tabla \#. 1

\begin{tabular}{|c|c|c|c|c|}
\hline No. & AÑO & RADICADO & INVESTIGACIÓN & VALOR \\
\hline 1 & 2015 & $\begin{array}{c}\text { SIPAD A- } \\
\text { DEARA-2015-67 }\end{array}$ & Pérdida proveedor de pistola & $\$ 256.447$ \\
\hline 2 & 2015 & $\begin{array}{c}\text { SIPAD A- } \\
\text { DEARA-2015-73 }\end{array}$ & Pérdida esposas policiales & $\$ 277.066$ \\
\hline 3 & 2015 & $\begin{array}{l}\text { SIPAD A- } \\
\text { DEARA-2015-70 }\end{array}$ & $\begin{array}{l}\text { Daños al vidrio panorámico delantero- } \\
\text { vehículo tipo camioneta }\end{array}$ & $\$ 1.150 .000$ \\
\hline 4 & 2015 & $\begin{array}{c}\text { SIPAD A- } \\
\text { DEARA-2015-57 }\end{array}$ & Daños vidrio trasero-vehículo tipo panel & $\$ 780.000$ \\
\hline 5 & 2015 & $\begin{array}{c}\text { SIPAD A- } \\
\text { DEARA-2015-33 }\end{array}$ & Daños a binoculares & $\$ 965.279$ \\
\hline 6 & 2015 & $\begin{array}{c}\text { SIPAD A- } \\
\text { DEARA-2015-50 }\end{array}$ & $\begin{array}{l}\text { Daños vidrio panorámico vehículo tipo } \\
\text { panel }\end{array}$ & $\$ 780.000$ \\
\hline 7 & 2015 & $\begin{array}{l}\text { SIPAD A- } \\
\text { DEARA-2015-5 }\end{array}$ & Daños esposas metálicas & $\$ 278.354$ \\
\hline 8 & 2015 & $\begin{array}{c}\text { SIPAD A- } \\
\text { DEARA-2015-72 }\end{array}$ & Daños binoculares & $\$ 1.095 .378$ \\
\hline 9 & 2015 & $\begin{array}{c}\text { SIPAD A- } \\
\text { DEARA-2015-69 }\end{array}$ & Daños binoculares & $\$ 1.095 .000$ \\
\hline 10 & 2015 & $\begin{array}{c}\text { SIPAD A- } \\
\text { DEARA-2015-11 }\end{array}$ & $\begin{array}{l}\text { Daños vidrio panorámico vehículo tipo } \\
\text { panel }\end{array}$ & $\$ 780.000$ \\
\hline & & & $\begin{array}{l}\text { Total valor monetario en pérdida y } \\
\text { daño de bienes del Estado }\end{array}$ & $\$ 7.457 .524$ \\
\hline
\end{tabular}




\section{Tabla \# 2.}

\begin{tabular}{|c|c|c|c|c|}
\hline No. & AÑO & RADICADO & INVESTIGACIÓN & VALOR \\
\hline 1 & 2016 & SIPAD A-DEARA-2016-17 & Daños motocicleta & $\$ 282.000$ \\
\hline 2 & 2016 & SIPAD A-DEARA-2016-5 & Pérdida elementos de laboratorio & $\$ 96.300$ \\
\hline 3 & 2016 & SIPAD A-DEARA-2016-4 & Pérdida esposas policiales & $\$ 278.354$ \\
\hline 4 & 2016 & SIPAD A-DEARA-2016-11 & Daños armamento & $\$ 86.985$ \\
\hline 5 & 2016 & SIPAD A-DEARA-2016-9 & $\begin{array}{l}\text { Daños vidrio panorámico delantero vehículo } \\
\text { tipo camioneta }\end{array}$ & $\$ 530.000$ \\
\hline 6 & 2016 & SIPAD A-DEARA-2016-1 & Daños ocasionados a vehículo & $\$ 200.000$ \\
\hline 7 & 2016 & SIPAD A-DEARA-2016-3 & Daños esposas policiales & $\$ 278.354$ \\
\hline 8 & 2016 & & Pérdida binocular & $\$ 1.095 .378$ \\
\hline 9 & 2016 & SIPAD A-DEARA-2016-18 & $\begin{array}{l}\text { Daños vehículo y motocicleta y lupa elementos } \\
\text { de otoscopia }\end{array}$ & $\$ 719.000$ \\
\hline 10 & 2016 & SIPAD A-DEARA-2016-41 & Daños revolver & $\$ 50.000$ \\
\hline 11 & 2016 & & Daños vehículo tipo buseta & $\$ 780.000$ \\
\hline 12 & 2016 & SIPAD A-DEARA-2016-15 & Pérdida par de esposas policiales & $\$ 509.328$ \\
\hline 13 & 2016 & SIPAD A-DEARA-2016-13 & Daños vehículo tipo camioneta & $\$ 780.000$ \\
\hline 14 & 2016 & SIPAD A-DEARA-2016-28 & Siniestro semoviente & $\$ 500.000$ \\
\hline 15 & 2016 & SIPAD A-DEARA-2016-27 & Daños visor nocturno & $\$ 372.522$ \\
\hline 16 & 2016 & SIPAD A-DEARA-2016-24 & Daños visor nocturno & $\$ 372.522$ \\
\hline 17 & 2016 & SIPAD A-DEARA-2016-37 & Daños pistola sig sauer y pérdida munición & $\$ 407.608$ \\
\hline 18 & 2016 & SIPAD A-DEARA-2016-43 & Daños pistola sig sauer & $\$ 919.904$ \\
\hline 19 & 2016 & SIPAD A-DEARA-2016-39 & Daños vehículo tipo camioneta & $\$ 463.350$ \\
\hline 20 & 2016 & SIPAD A-DEARA-2016-49 & Daños motocicleta & $\$ 238.000$ \\
\hline 21 & 2016 & SIPAD A-DEARA-2016-57 & Daños fusil & $\$ 20.000$ \\
\hline 22 & 2016 & SIPAD A-DEARA-2016-56 & Daños vehículo tipo camioneta & $\$ 600.000$ \\
\hline 23 & 2016 & SIPAD A-DEARA-2016-44 & Daño esposas policiales & $\$ 278.354$ \\
\hline 24 & 2016 & SIPAD A-DEARA-2016-54 & Daños vehículo tipo camioneta & $\$ 400.000$ \\
\hline 25 & 2016 & SIPAD A-DEARA-2016-34 & Daños motocicleta & $\$ 75.000$ \\
\hline 26 & 2016 & SIPAD A-DEARA-2016-33 & Daños fusil & $\$ 1.085 .852$ \\
\hline 27 & 2016 & SIPAD A-DEARA-2016-22 & Daños pistola & $\$ 408.602$ \\
\hline 28 & 2016 & SIPAD A-DEARA-2016-42 & Daños fusil, pérdida proveedores y munición & $\$ 1.372 .642$ \\
\hline 29 & 2016 & SIPAD A-DEARA-2016-10 & Daños motocicleta & $\$ 673.800$ \\
\hline \multirow[t]{2}{*}{30} & 2016 & SIPAD A-DEARA-2016-6 & Daños motocicleta & $\$ 230.000$ \\
\hline & & & $\begin{array}{c}\text { Total valor monetario en pérdida y daño de } \\
\text { bienes del Estado }\end{array}$ & $\$ 12.814 .527$ \\
\hline
\end{tabular}


Tabla de sueldos funcionarios exclusivos encargados de adelantar investigaciones por pérdida o daño de bienes de propiedad del ramo de la Defensa Nacional, conforme los parámetros de la Ley 1476 de 2011

\section{Tabla \# 3}

\begin{tabular}{|c|c|c|c|}
\hline GRADOS & $\begin{array}{l}\text { CARGO O } \\
\text { FUNCIÓN }\end{array}$ & $\begin{array}{l}\text { DEVENGADO EN PESOS } \\
\text { COLOMBIANOS POR } \\
\text { MES LABORADO }\end{array}$ & $\begin{array}{c}\text { DEVENGADO EN PESOS } \\
\text { COLOMBIANOS POR } \\
\text { AÑO LABORADO }\end{array}$ \\
\hline Subteniente & Asesor Jurídico & $\$ 2.938 .595,77$ & $\$ 35.263 .149,24$ \\
\hline Patrullero & $\begin{array}{l}\text { Sustanciador } \\
\text { primera } \\
\text { instancia }\end{array}$ & $\$ 1.889 .914,50$ & $\$ 22.678 .974,00$ \\
\hline Patrullero & $\begin{array}{l}\text { Sustanciador } \\
\text { segunda } \\
\text { instancia }\end{array}$ & $\$ 1.889 .914,50$ & $\$ 22.678 .974,00$ \\
\hline \multicolumn{2}{|c|}{$\begin{array}{l}\text { TOTAL PAGO } \\
\text { FUNCIONARIOS }\end{array}$} & $\$$ 6.718.423.00 & $\$ 80.621 .097 .00$ \\
\hline
\end{tabular}

Así las cosas, prima facie se puede colegir, que el Estado acarrea costos mayores en lo que respecta a la tramitación de investigaciones administrativas abreviadas por pérdida o daño de bienes de propiedad del Ministerio de Defensa Nacional-Policía Nacional. Sin embargo, se debe tener en cuenta varios aspectos entre ellos los relacionados con los costes fijos y costes variables, el primero se explica de la siguiente forma:

(...) consisten en conceptos tales como el alquiler de una fábrica o del espacio de oficinas, los pagos contractuales por el equipo, los pagos de intereses sobre los créditos, los salarios de la planta de profesores, etc. Los mismos deben pagarse incluso si la empresa no produce nada y no se modifican si la producción lo hace. Por ejemplo un despacho de abogados puede pagar un alquiler de oficinas con duración de 10 años, lo cual sigue siendo una obligación incluso si la empresa se reduce a la mitad de su tamaño original. (Samuelson \& Nordhaus, 1948, pág. 123). 
Por su parte "Los costes variables son aquellos que se modifican cuando la producción cambia” (Samuelson \& Nordhaus, 1948, pág. 123). En perspectiva del coste fijo y variable, se deben analizar los anteriores valores que se han presentado en este apartado, toda vez que el ramo de la defensa nacional, responde de igual forma a la lógica económica aquí planteada. En tal sentido se extrae que el pago efectuado a funcionarios de dedicación exclusiva en las investigaciones abreviadas superan los ochenta millones de pesos $(\$ 80.000 .000)$, ello sin incluir el coste fijo de la entidad. A su vez las investigaciones por pérdidas o daño de bienes del Estado por año promedio no superan los trece millones de pesos $(\$ 13.000 .000)$ según la información recopilada de los años 2015 y 2016 en el Departamento de Policía Arauca (ver tablas \# 1 y 2). En tal lógica, se pensaría que no es conveniente desde el punto de vista del valor monetario investigar por esta figura dado que le resultaría mucho más costoso para el Estado. Sin embargo antes de entrar a tomar una postura al respecto, se debe considerar otro aspecto importante como el coste de oportunidad, el cual está relacionado con las decisiones que se deben tomar respecto de las investigaciones de carácter abreviada, es decir "debemos considerar en cada caso cuánto costará la decisión en términos de las oportunidades que se dejan ir" (Samuelson \& Nordhaus, 1948, pág. 12). Bajo la anterior óptica, se dispone entonces de tres aspectos importantes a tener en cuenta el primero el coste fijo, al respecto se dirá que la Entidad referida, adelante o no investigaciones debe incurrir en unos gastos de funcionamiento, en tal orden se debe descontar ese valor, toda vez que no es lógico incluirlo partiendo de la anterior argumentación, en segundo lugar el coste variable es donde se adentra con el fin de establecer la conveniencia del trámite de investigaciones por la figura abreviada, en la que se puede establecer que el radicado por año analizado cambió sustancialmente, toda vez que en el año 2015 ingresaron diez (10) investigaciones de menor cuantía, no obstante en el año siguiente 2016 el aumento fue sustancial al llegar a completar treinta (30) 
investigaciones de menor cuantía, bajo ese análisis se puede determinar que es variable el radicado de investigaciones y en tal sentido no se podría afirmar si existe una pérdida o ganancia para la Entidad en mención. El tercer aspecto está relacionado con el coste de oportunidad que será abordado de la siguiente forma: (i) ¿Cómo sería el manejo de los bienes al interior del Ministerio de Defensa Nacional, sus entidades adscritas o vinculadas a la Fuerza Pública, si no se investigará por perdida o daño de bienes de menor cuantía?, (ii) ¿Cuál sería la mejor decisión en materia de coste de oportunidad para la Entidad referida?, una posible respuesta al primer interrogante sería que los funcionarios de ese ministerio, dado que no se investiga la pérdida o daño de bienes de menor cuantía, no asumirían la guarda, cuidado y adecuado manejo de los bienes puestos bajo su responsabilidad, en tal sentido la pérdida para esa entidad sería mucho más costosa en términos monetarios, dado que a futuro repercutiría no solo con las finanzas de la entidad, sino también con la calidad del servicio que estas prestan. Por tal motivo, la mejor decisión en materia de coste de oportunidad sería la que el Estado sin importar las variables que se puedan llegar a presentar con relación a las investigaciones de mínima cuantía, debe continuar adelantando sus investigaciones en esta materia, con el fin a su vez de enviar el mensaje a los funcionarios que hacen parte del ramo de la defensa nacional, que sin importar el costo de la operación, la administración adelantará consecutivamente las averiguaciones correspondientes por pérdida o daño de bienes de su propiedad, asimismo de encontrar responsables, estos responderán patrimonialmente. De igual forma es importante que el Estado, a través de cada una de las entidades que aplican el procedimiento abreviado, forme a sus funcionarios, es decir brinde capacitaciones respecto del cuidado, manejo y conservación de los bienes que le son asignados para la prestación del servicio hacia la comunidad. 


\section{B. Las entidades que ejercen la facultad de aplicación del procedimiento abreviado: según su competencia}

En este apartado, es importante conocer en primer lugar el ámbito de aplicación de la Ley 1476 de 2011, sus destinatarios y en segundo lugar a las entidades que conforme su naturaleza Constitucional o legal, tienen la potestad de aplicar el procedimiento abreviado. En ese orden de ideas, en primer lugar la Ley en mención establece en su parte sustantiva ${ }^{40}$, que se aplicarán las disposiciones contenidas en la presente norma, cuando sus destinatarios ${ }^{41}$, entiéndase por personas naturales que presten sus servicios al Ministerio de Defensa Nacional, sus Entidades adscritas o vinculadas a la Fuerza Pública o se encuentren como contratistas en la modalidad de trabajadores oficiales, prestación de servicios u otra modalidad, o hayan prestado sus servicios a dicho Ministerio Público, y den lugar a pérdida o daño de bienes, es decir que la norma se activa cuando algún funcionario de los antes mencionados pierdan o dañen bienes de propiedad del ramo de la Defensa Nacional. Por su parte en segundo lugar las entidades que pueden dar aplicabilidad a las disposiciones descritas en la Ley 1476 de 2011, son conforme la naturaleza jurídica de las mismas, establecida desde la propia Constitución Política de Colombia, en su artículo $216^{42}$ establece

\footnotetext{
${ }^{40}$ ARTÍCULO 12. ÁMBITO DE APLICACIÓN. Las disposiciones contenidas en la presente ley se aplicarán a sus destinatarios cuando den lugar a la pérdida o daño de bienes de propiedad o al servicio del Ministerio de Defensa Nacional, sus entidades adscritas o vinculadas o la Fuerza Pública.

${ }^{41}$ ARTÍCULO 13. DESTINATARIOS. Son destinatarios las personas naturales que presten sus servicios en el Ministerio de Defensa Nacional, sus entidades adscritas o vinculadas o la Fuerza Pública, los alumnos de las escuelas de formación y quienes presten servicio militar obligatorio en la Fuerza Pública, aunque con posterioridad se hayan retirado.

También se aplicará a las personas naturales contratadas como trabajador oficial, por prestación de servicios u otra modalidad.

El personal que preste el servicio militar obligatorio en las Fuerzas Militares o en la Policía Nacional, será sujeto de la actuación administrativa, aunque ya no se encuentre prestando dicho servicio.

${ }^{42}$ Artículo 216. La fuerza pública estará integrada en forma exclusiva por las Fuerzas Militares y la Policía Nacional. Todos los colombianos están obligados a tomar las armas cuando las necesidades públicas lo exijan para defender la independencia nacional y las instituciones públicas.

La Ley determinará las condiciones que en todo tiempo eximen del servicio militar y las prerrogativas por la prestación del mismo.
} 
que la Fuerza Pública está integrada exclusivamente por las Fuerzas Militares y la Policía

Nacional, seguidamente el artículo $217^{43}$ superior, establece que las Fuerzas Militares, están constituidas por el Ejército, Armada y Fuerza Aérea, las cuales tienen como misión fundamental, la defensa de la soberanía, la independencia, la integridad del territorio nacional y el orden constitucional. De igual forma el artículo $218^{44}$ de la Constitución Política de Colombia, le asignó a la Policía Nacional el mantenimiento de condiciones necesarias para el ejercicio de derechos y libertades públicas, y el aseguramiento de que todas las personas residentes en Colombia convivan en paz. Asimismo desde el aspecto legal, el artículo 1.1.1.1 del Decreto 1070 de $2015^{45}$, establece la integración del sector defensa. Además indica que el Ministerio de Defensa Nacional, tendrá a su cargo la orientación, control y evaluación del ejercicio de las funciones de los organismos y entidades que conforman el sector administrativo Defensa Nacional. Menciona igualmente que la Dirección del Ministerio de Defensa Nacional está a cargo del Ministro, quien la ejerce con colaboración del Comandante General de las Fuerzas Militares, los Comandantes de Fuerza, el Director General de la Policía Nacional y los Viceministros.

\footnotetext{
${ }^{43}$ Artículo 217.La Nación tendrá para su defensa unas Fuerzas Militares permanentes constituidas por el Ejército, la Armada y la Fuerza Aérea. Las Fuerzas Militares tendrán como finalidad primordial la defensa de la soberanía, la independencia, la integridad del territorio nacional y del orden constitucional.

La Ley determinará el sistema de reemplazos en las Fuerzas Militares, así como los ascensos, derechos y obligaciones de sus miembros y el régimen especial de carrera, prestacional y disciplinario, que les es propio. ${ }^{44}$ Artículo 218.La ley organizará el cuerpo de Policía.

La Policía Nacional es un cuerpo armado permanente de naturaleza civil, a cargo de la Nación, cuyo fin primordial es el mantenimiento de las condiciones necesarias para el ejercicio de los derechos y libertades públicas, y para asegurar que los habitantes de Colombia convivan en paz.

La ley determinará su régimen de carrera, prestacional y disciplinario.

${ }^{45}$ Decreto 1070 de 2015 "Por el cual se expide el Decreto Único Reglamentario del Sector Administrativo de Defensa", artículo 1.1.1.1. El Ministerio de Defensa Nacional. El Sector Administrativo Defensa Nacional está integrado por el Ministerio de Defensa Nacional y sus entidades adscritas y vinculadas.

El Ministerio de Defensa Nacional tendrá a su cargo la orientación, control y evaluación del ejercicio de las funciones de los organismos y entidades que conforman el Sector Administrativo Defensa Nacional, sin perjuicio de las potestades de decisión que les correspondan así como de su participación en la formulación de la política, en la elaboración de los programas sectoriales y en la ejecución de los mismos.
} 
Ahora bien es preciso mencionar las entidades que de conformidad con la ley hacen parte de forma adscritas al Ministerio de Defensa Nacional, las cuales tienen a su vez la facultad de adelantar investigaciones administrativas por perdida o daño de bienes conforme lo establece la Ley 1476 de 2011. Dicho de este modo, el artículo 1.2.1.1.1. ${ }^{46}$, establece a la Superintendencia de Vigilancia y Seguridad Privada, como una entidad adscrita al Ministerio de Defensa Nacional, la cual tiene como misión ejercer el control, la inspección y vigilancia sobre la industria y los servicios de vigilancia y seguridad privada.

En su orden el artículo 1.2.1.2.1 del Decreto en mención ${ }^{47}$, hace alusión a los establecimientos públicos del sector Defensa, el artículo 1.2.2.1.148, establece cuales son las

${ }^{46}$ Decreto 1070 artículo 1.2.1.1.1. La Superintendencia de Vigilancia y Seguridad Privada. Organismo del orden nacional, de carácter técnico, adscrito al Ministerio de Defensa Nacional, con personería jurídica, autonomía administrativa y financiera. Le corresponde ejercer el control, inspección y vigilancia sobre la industria y los servicios de vigilancia y seguridad privada.

1. $\quad{ }^{47}$ Caja de Retiro de las Fuerzas Militares. La cual tiene como misión u objeto, pagar y reconocer las asignaciones de retiro del personal de Oficiales, Suboficiales y Soldados Profesionales de las Fuerzas Militares que consoliden tal derecho.

2. Caja de Sueldos y Retiro de la Policía Nacional. La cual como la anterior debe pagar y reconocer las asignaciones de retiro del personal de Oficiales, Suboficiales, personal del Nivel Ejecutivo, agentes y demás estamentos de la Policía Nacional que adquieran el derecho a tal prestación.

3. Hospital Militar Central. Que tiene como objeto prestar servicios de salud a los afiliados y beneficiarios del sistema de salud de las Fuerzas Militares y de la Policía Nacional.

4. Agencia Logística de las Fuerzas Militares. Ejecuta las actividades de apoyo logístico y abastecimiento de bienes y servicios requeridos para atender las necesidades de las Fuerzas Militares.

5. Fondo Rotatorio de la Policía Nacional. Desarrolla políticas y planes relacionados con la adquisición, producción, comercialización, representación y distribución de bienes y servicios, para el normal funcionamiento de la Policía Nacional y el apoyo de sus integrantes, sector defensa, seguridad nacional y demás entidades estatales.

6. Instituto de Casas Fiscales del Ejército. Desarrolla la política y los planes generales de vivienda por el sistema de arrendamiento que adopte el Gobierno Nacional, respecto de Oficiales y Suboficiales en servicio activo y personal civil del Ejército.

7. Club Militar. Contribuye al desarrollo de la política y los planes generales que en materia de bienestar social y cultural adopte el Gobierno Nacional en relación con el personal de oficiales en actividad o en retiro de las Fuerzas Militares y la Policía Nacional.

8. Defensa Civil Colombiana. Le corresponde la prevención inminente y atención inmediata de los desastres y calamidades y como integrante del Sistema Nacional para la Prevención y Atención de Desastres. (...)

1. ${ }^{48}$ Industria Militar. Desarrolla la política general del Gobierno en materia de importación, fabricación y comercio de armas, municiones y explosivos y elementos complementarios.

2. Caja Promotora de Vivienda Militar y de Policía. Facilita a sus afiliados la adquisición de vivienda propia, mediante la realización o promoción de todas las operaciones del mercado inmobiliario, incluida la captación, intermediación y administración del ahorro de sus afiliados. 
entidades vinculadas, entre las que se encuentran las Empresas Industriales y Comerciales del Estado-Sector Defensa, y el artículo 1.2.2.2.1 ${ }^{49}$ determina las sociedades de economía mixtas, por su parte el artículo $1.2 .3 .1^{50}$, consagra la existencia de varias entidades descentralizadas indirectas del sector Defensa ${ }^{51}$.

\section{Capitulo Segundo}

\section{LOS TÉRMINOS PROCESALES EN EL PROCEDIMIENTO ABREVIADO VISTO DESDE EL ÁMBITO JURISPRUDENCIAL Y PRÁCTICO DOS ASPECTOS QUE DESCUBREN POSIBLES VULNERACIONES AL DEBIDO PROCESO}

En el presente capitulo, se analizarán varias decisiones del Consejo de Estado y de la Corte Constitucional, relacionadas con el plazo razonable, incumplimiento de términos procesales por parte de los despachos judiciales y brevedad de procedimientos legales enmarcados dentro de investigaciones de carácter administrativas. De igual forma se estudiará el aspecto práctico y subjetivo que guarda el procedimiento abreviado, desde la perspectiva del debido

1. ${ }^{49}$ Servicio Aéreo a Territorios Nacionales S.A., SATENA S.A. Tiene por objeto la prestación del servicio aéreo de pasajeros, correo y carga en el territorio nacional y en el exterior, correo y carga de cualquier naturaleza

2. Corporación de la Industria Aeronáutica Colombiana S.A., CIAC S.A. Tiene por objeto, organiza, construir, promover y explotar centros de reparación, entrenamiento aeronáutico, mantenimiento y ensamble de aeronaves y sus componentes y la importación, comercialización y distribución de repuestos, piezas, quipos y demás elementos necesarios para la prestación del servicio aeronáuticos y aeroportuarios.

3. Sociedad Hotelera S.A. El objeto es la explotación de la industria hotelera y la administración directa o indirecta de hoteles, negocios conexos y servicios complementarios.

1. ${ }^{50}$ Corporación de Ciencia y Tecnología para el Desarrollo de la Industria Naval, Marítima y FluvialCOTECMAR. Desarrolla y ejecuta la investigación, transferencia y aplicación de tecnología para la industria naval, marítima y fluvial.

2. Corporación de Alta Tecnología para la Defensa, CODALTEC. Tiene por objeto el desarrollo, la promoción y la realización de actividades de ciencia, tecnología e innovación.

${ }^{51}$ Véase la estructura orgánica del Ministerio de Defensa Nacional.

https://www.mindefensa.gov.co/irj/portal/Mindefensa/contenido?NavigationTarget=navurl://1494c44e259664 $\underline{6 d 35 f 4060084 f d 9 b 02}$. 
proceso Constitucional. Por tanto se hace necesario realizar de forma aleatoria el análisis de casos, relacionados con hechos donde se investigan pérdidas o daños de bienes de propiedad del ramo de la Defensa Nacional y se planteará a su vez desde la regla del debido proceso, el plazo razonable o adecuado que debe enmarcar las investigaciones que se adelanten a través de la aplicación del procedimiento abreviado.

En ese orden de ideas se hace necesario explicar previamente en que consiste el debido proceso, toda vez que durante el desarrollo de las siguientes secciones, se realizarán constantemente referencias a este derecho de rango constitucional y a su vez expresado como principio normativo. Así las cosas el debido proceso según (Carvajal, 2010), debe ser visto desde tres puntos de vista:

(i) Desde el punto de vista formal, el cual nos indica que aparece como norma de rango constitucional conforme lo establece el artículo 29 de la CP, lo cual significa que debe ser visto de arriba hacia abajo, atendiendo a la lógica de la jerarquía de las normas, desarrollándose y determinándose por la ley y luego por el reglamento. (ii) estructura normativa, la cual consiste en una norma jurídica de principio, relacionada con otras normas que orientan la actividad de la administración y desprende a su vez otros subprincipios y reglas. Y (iii) material o sustancialmente, el debido proceso es un derecho fundamental que subjetiva u objetivamente incorpora una serie de garantías procesales, tales como publicidad, derecho de defensa, reglas probatorias, presunción de inocencia, impugnación, objeciones y recursos. (Carvajal, 2010, pág. 9),

Asimismo el debido proceso es "el adelantamiento de las etapas del proceso y el cumplimiento de las distintas actuaciones judiciales con sujeción a las garantías 
constitucionales y legales, como límite a la función punitiva del Estado" (Lopez Toro, 2002, pág. 33$)^{52}$.

El debido proceso debe ser garantizado en toda clase de actuaciones, tanto judiciales como administrativas, lo cual permite que toda persona disponga de esta garantía en todos los escenarios donde se pretenda establecer algún tipo de responsabilidad por leve o grave que sea el asunto a tratar, estas prerrogativas constitucionales nos las exponen de la siguiente manera:

(...) todos los sistemas modernos generalmente proveen un conjunto de garantías procesales a los litigantes, a nivel de regulaciones de ley ordinaria, tanto como al nivel de principios constitucionales e internacionales. Garantías como el "derecho a la acción", el "derecho a un juicio justo" y la "oportunidad de ser oído" se incluyen usualmente en el inventario de derechos fundamentales. Ellos importan que las partes tienen el derecho a acceder al tribunal a efectos de interponer demandas civiles, el derecho a determinar el objeto de las disputas civiles y a perseguir una compensación adecuada, el derecho a presentar la prueba disponible, así como el derecho a hacer ver los argumentos legales y fácticos en apoyo de sus respectivas pretensiones.

Dentro de este complejo conjunto de derechos, uno particularmente importante es el derecho a la prueba. Usualmente se lo define como el derecho de toda parte para producir toda la prueba relevante que esté en su posesión, para obtener la presentación de prueba relevante que esté en posesión de otras partes o de terceros, y que toda esa prueba sea debidamente considerada por el tribunal. El derecho a la prueba es un aspecto fundamental del derecho de acción y a la defensa en realidad, sería un sinsentido decir que las partes pueden ejercer estos derechos pero que no se les permite probar por ningún medio disponible las aseveraciones fácticas que son la base de sus pretensiones y defensas. (Taruffo, 2008, pág. 79)

\footnotetext{
${ }^{52}$ LÓPEZ TORO, Wilfor. El debido proceso. Pereira 2002. Pág. 33
} 
Como se ha mencionado anteriormente el debido proceso per se enmarca varias dimensiones, sin embargo cada una de ellas abarca escenarios, que a su vez garantizan la materialización del mismo, en ese sentido el principio de legalidad arraigado como una dimensión del debido proceso, nos indica el deber de motivación con las razones justificativas de las decisiones tomadas en el marco de una actuación administrativa o judicial, para lo cual el texto que será presentado a continuación explica los anteriores aspectos de la siguiente manera:

Una de las dimensiones del debido proceso es la motivación del acto, según se desprende de la expresión con observancia de la plenitud de las formas de que trata el art. 29 CN., todo acto debe ser motivado con expresión de las razones justificativas como desarrollo del principio de legalidad, para determinar si este se ajusta a la ley o si la motivación de las decisiones garantiza el cumplimiento de los principios rectores de la administración pública, contenidos en el artículo 209 de la CN”. (Lopez Toro, 2002, pág. 36) ${ }^{53}$

Teniendo en cuenta lo anterior, relacionado con lo dimensional que encierra el debido proceso, será analizado uno de los aspectos importantes dentro de esa prerrogativa constitucional referente al derecho de defensa objeto de análisis, este se encuentra objetivamente incorporado al debido proceso $^{54}$, el cual consiste en la posibilidad de realizar una defensa desde el punto de vista técnica, es decir a través de un profesional del derecho, o material, que sería la defensa ejercida por el propio investigado. El derecho de defensa según (Ferrajoli, 1995) ${ }^{55}$, corresponde a la naturaleza misma de conservación de cada hombre, es decir que por instinto de preservación el ser humano siempre procurará defenderse. Por consiguiente y atendiendo al sentido común de las cosas, todo procedimiento debe permitir el ejercicio mismo de la defensa, toda vez que el investigado debe saber de qué

\footnotetext{
${ }^{53}$ LOPEZ TORO. Wilfor. El Debido Proceso

${ }^{54}$ Artículo $29 \mathrm{CP}$

${ }^{55}$ FERRAJOLI, Luigi, pp. 333-989.
} 
se le acusa o atribuye, de igual forma tener acceso al expediente, rendir descargos, defenderse a través de un abogado o en representación propia cuando las normas lo permitan, presentar pruebas y controvertir todas aquellas que le sean allegadas en su contra, participar en todas las diligencias probatorias que le soliciten u ordene el despacho que adelanta la investigación, presentar alegatos y recursos. etc. Lo anterior nos permite inferir que el investigado debe estar presente en todas y cada una de las etapas de la investigación desde la génesis misma hasta su culminación, y gozar de unos plazos adecuados, razonables que permitan materializar de manera efectiva todas y cada una de las garantías constitucionales antes referidas.

\section{SECCIÓN 1. BREVE MIRADA DE LOS TÉRMINOS PROCESALES DESDE LAS ESFERAS DEL PLAZO RAZONABLE, INCUMPLIMIENTOS Y EXCESIVA BREVEDAD A LA LUZ DE LA JURISPRUDENCIA COLOMBIANA}

Los términos procesales como elemento importante del debido proceso, es un aspecto que se debe estudiar desde el contexto de la jurisprudencia Colombiana del Consejo de Estado y de la Corte Constitucional, toda vez que el procedimiento abreviado visto desde las actuaciones fiscales, administrativas o disciplinarias, conllevan su análisis en primer lugar desde el ámbito del (i) plazo razonable: Es decir, poder establecer o determinar unos tiempos adecuados dentro de los procedimientos que respondan positivamente a las garantías constitucionales del debido proceso, en especial el respeto por el derecho a la defensa técnica y material de los investigados y la posibilidad de presentar y controvertir pruebas. (ii) cumplimientos e incumplimiento de términos procesales: Determinar dentro de este análisis que decisiones de fondo se han establecidos por parte de las Cortes de cierre en materia de lo 
Contencioso Administrativo y Constitucional, respecto a los incumplimientos de términos procesales que se gestan en el desarrollo de las actuaciones judiciales o administrativas y (iii) excesiva brevedad: Establecer con claridad cuando se está frente a un procedimiento excesivamente breve, conforme el análisis de las razones para decidir de las mencionadas Corporaciones. Por tanto y con base en el criterio jurisprudencial, se establecerá con claridad los tiempos adecuados que se deben aplicar, a partir del desarrollo del procedimiento abreviado de la ley 1476 de $2011^{56}$. Lo anterior permitirá identificar con claridad aquellos procedimientos de índole abreviados que per se podrían generar vulneraciones al debido proceso constitucional, considerando las razones de las decisiones que establezcan para estos temas las altas Cortes que se estudian en el marco de los procedimientos, desde los escenarios del plazo razonable, excesiva brevedad y cumplimientos e incumplimiento de los términos procesales dentro de las actuaciones judiciales o administrativas.

\section{A. Los términos procesales según el Consejo de Estado}

Es importante para la temática que se estudia, traer a relación varios pronunciamientos del Consejo de Estado, desde varias perspectivas como lo son el plazo razonable, incumplimientos y excesiva brevedad de términos procesales, toda vez que como Corte de cierre, es la encargada de establecer las pautas y los parámetros a seguir en la jurisdicción de lo contencioso administrativo.

\footnotetext{
${ }^{56}$ ARTÍCULO 94. PROCEDIMIENTO ABREVIADO. Cuando la cuantía del bien perdido o del daño tenga un valor inferior a dos (2) salarios mínimos legales mensuales vigentes (smlmv), el competente adelantará el siguiente procedimiento: escuchará al presunto responsable en diligencia de descargos; dispondrá y recaudará, dentro del término de cinco (5) días hábiles más el término de la distancia si fuere necesario, las pruebas a que haya lugar y proferirá fallo escrito y motivado de única instancia dentro de los tres (3) días hábiles siguientes, contra el cual solamente procederá recurso de reposición. La notificación se hará acorde con lo dispuesto en la presente ley.
} 
En ese orden de ideas, en sentencia del año 2012 el Consejo de Estado ${ }^{57}$, máxima autoridad en materia de lo contencioso administrativo, en esa oportunidad hace la claridad que si bien es cierto lo lógico es que se cumplan los términos procesales en el escenario judicial o administrativo, su incumplimiento per se no genera invalidez de la decisión, ni actos fictos o presuntos, es decir que a pesar de romperse con los tiempos establecidos para cada actividad o etapa procesal, el pronunciamiento que le pone fin a dicho proceso, tiene plena validez para las partes. No obstante dicha Corporación aclara que el funcionario competente podrá responder por la demora en la resolución del caso, cuando ésta sea injustificada.

De igual forma en sentencia del año 2013 el Consejo de Estado Sala de lo contencioso administrativo $^{58}$, conociendo de una demanda de nulidad, en contra de la Policía Nacional, por la cual dicha institución responsabilizó administrativamente a un agente de la policía por la pérdida de unos bienes de propiedad de dicha institución, en lo relacionado a los términos procesales que establecía en su vigencia el decreto 791 de $1979^{59}$, dijo:

"El citado decreto por ser autónomo e independiente consagró que el incumplimiento de los términos procesales genera responsabilidad disciplinaria en cabeza del funcionario competente que por descuido o desidia no adelante las actuaciones correspondientes en tiempo. (...) En consecuencia, el vencimiento de los términos bien sea para la investigación o el fallo dentro de la acción administrativa del ramo de defensa, no constituye causal que invalide las actuaciones desarrolladas al interior del proceso, ni de nulidad de los actos impugnados".

Se colige de lo anteriormente expresado por el Honorable Consejo de Estado, que el incumplimiento de los términos procesales que enmarcan las actuaciones procedimentales, no le restan validez a las decisiones, ni a las pruebas recaudadas y actos impugnados, sin

\footnotetext{
${ }^{57}$ Expediente 25000-23-27-000-2006-01364-01 del 12 de abril de 2012. Consejo de Estado, sala de lo contencioso administrativo, sección cuarta. CP. HUGO FERNANDO BASTIDAS BARCENAS.

${ }^{58}$ Expediente 25000-23-25-000-2005-07609-01(0462-09) del 17 de abril de 2013. Consejo de Estado, sala de lo contencioso administrativo. Sección segunda, subsección A. C.P. ALFONSO VARGAS RINCON.

${ }^{59}$ Decreto 791 de 1979, Por el cual se aprueba el Reglamento de Procesos Administrativos por pérdidas o daños de los bienes destinados al servicio del Ramo de Defensa Nacional
} 
embargo será directamente responsable el funcionario con la competencia legal, contra quien recaerá las investigaciones correspondientes relacionadas con las demoras o tardanzas al interior de los procesos.

Ese mismo año el Consejo de Estado, la sala de lo contencioso administrativo ${ }^{60}$, conociendo de una demanda de nulidad y restablecimiento del derecho, mediante la cual, la demandante alegaba la inexistencia de pruebas, ya que las mismas fueron extemporáneas. Al respecto expreso la Corporación:

"El hecho de que se excedan los términos dispuestos para efecto de adelantar la investigación disciplinaria y la formulación del pliego de cargos, no implica que los elementos materiales probatorios allegados pierdan valor, siempre que no se exceda el término de prescripción, mientras se respeten las garantías derivadas del debido proceso, como por ejemplo las relacionadas con la solicitud, aporte y práctica de pruebas, así como el derecho a controvertir las allegadas, entre otras".

En esa ocasión el Consejo de Estado, se refirió al incumplimiento de términos en lo relacionado al recaudo y práctica de las pruebas dentro de un proceso de carácter disciplinario, manifestando al igual que los anteriores pronunciamientos que la extemporaneidad o el incumplimiento de términos procesales no le resta validez a las decisiones, así como tampoco a las pruebas que se recaudan en el desarrollo de los procesos.

En ese mismo sentido, en el año 2015 el Consejo de Estado ${ }^{61}$, conociendo de una acción de tutela contra sentencia judicial, afirmo que el plazo razonable en cuanto a su relación con los términos procesales, debían involucrar: (i) la complejidad del asunto, (ii) actividad procesal del interesado y (iii) el análisis global del procedimiento. Postura que fue tomada

\footnotetext{
${ }^{60}$ Expediente 11001-03-25-000-2011-00059-00(0184-11) del 7 de marzo de 2013, Consejo de Estado, sala de lo contencioso administrativo, sección segunda, subsección A, C.P. Alfonso Vargas Rincón.

${ }^{61}$ Expediente 11001-03-15-000-2015-02866-00, del 15 de diciembre de 2015. Consejo de Estado, sala de lo contencioso administrativo, sección segunda, subsección A. C.P. Gabriel Valbuena Hernández.
} 
ese mismo año por la sección tercera, subsección A, de la misma Corporación ${ }^{62}$, remplazando el tercer aspecto, del pronunciamiento anteriormente mencionado, por la conducta de las autoridades judiciales.

Respecto de la Sentencia analizada, se colige en cuanto a la complejidad del caso como primer planteamiento, que la razonabilidad del plazo en los términos procesales, involucra varios aspectos importantes entre los cuales se encuentra: la cantidad de testigos en el asunto que se investiga, facultades de la autoridad, naturaleza de la investigación, orden público entre otros. El segundo planteamiento, relacionado con la participación procesal del interesado, el cual debe estar dispuesto a asumir de manera activa y responsable su participación en la investigación, como último planteamiento se tiene la conducta de la autoridad, la cual se debe enmarcar dentro del escenario procesal de manera diligente, pronta y oportuna, obrando siempre con la mayor diligencia del caso. Estos aspectos a los que hace alusión el Consejo de Estado, corresponden a los escenarios actuales donde convergen las actividades judiciales y administrativas, es decir, se parte que ya se cuenta con un procedimiento establecido y no se reprochan los términos como tal, sino que hace alusión al comportamiento de la autoridad y del interesado en el ejercicio de la actividad jurídica. No obstante, se tomará como base para este estudio dichas consideraciones en aras de establecer un planteamiento en cuanto a términos y actuación procesal en el procedimiento abreviado que regula la ley 1476 de 2011.

\footnotetext{
${ }^{62}$ Expediente 47001-23-33-000-2015-00316-01 del 11 de noviembre de 2015. Consejo de Estado, sala de lo contencioso administrativo, sección tercera, subsección A. C.P. HERNAN ANDRADE RINCON.
} 
Posterior al anterior pronunciamiento, se profirió en el año 2016, la sentencia del Consejo de Estado, sala de lo contencioso administrativo ${ }^{63}$, conociendo del medio de control de nulidad y restablecimiento del derecho, en atención a una sanción disciplinaria de la que fue objeto el demandante, el cual alegaba el incumplimiento de términos procesales, el máximo tribunal de lo contencioso expresó lo siguiente:

"Se insiste entonces, que el incumplimiento de los términos procesales no se traduce en un elemento sustancial para la pérdida de competencia de la Oficina de Control Interno Disciplinario del Instituto Colombiano de Bienestar Familiar en el ejercicio de la potestad disciplinaria para tramitar el proceso administrativo en contra del actor; tampoco el legislador ha previsto el incumplimiento de los términos procesales como causal de nulidad del proceso disciplinario, ni esa circunstancia afecta la validez de las pruebas recaudadas. Por estas razones, el cargo de violación al debido proceso por las situaciones alegadas por el demandante no está llamado a prosperar".

Nótese como esta sentencia siguen la línea de la anterior, en afirmar de nuevo que el incumplimiento de los términos procesales no genera pérdida de competencia para el funcionario que adelanta la investigación, de igual forma expresa la jurisprudencia que dicho incumplimiento no le resta validez a las pruebas recaudadas, y tampoco a la decisión que se adopte.

Una vez presentada las anteriores sentencias del Consejo de Estado, con relación a demandas presentadas por ciudadanos que alegaban vulneraciones al debido proceso, por incumplimiento de términos procesales en distintos escenarios procesales, quedando claro que el máximo órgano de lo contencioso administrativo, ha establecido una postura firme en lo que concierne a esa situación, toda vez que por una parte expresa fuertemente que se debe respetar el principio de legalidad, respetando en todo momento y lugar los términos que establecen las leyes de cara a los procesos, de igual forma indica que el incumplimiento de

\footnotetext{
${ }^{63}$ Expediente 11001-03-25-000-2010-00298-00(2416-10) del doce (12) de octubre de dos mil dieciséis (2016). Consejo de Estado, sala de lo contencioso administrativo. Sección segunda, subsección B. C.P. CESAR PALOMINO CORTES.
} 
términos procesales acarreará sanciones de carácter disciplinarias a los funcionarios encargados de adelantar las investigaciones en el marco de los procedimientos que los rigen en particular y por otro lado deja sentado que si bien es cierto se pueden generar incumplimiento de términos procesales, dichos incumplimientos no le restan validez a las decisiones que sean proferidas, ni a las pruebas que sean recaudadas.

\section{B. Los términos procesales según la Corte Constitucional}

En este apartado, se estudiarán las decisiones proferidas por la Corte Constitucional en lo que tiene que ver con el principio del debido proceso y los términos procesales, desde la óptica del plazo razonable, excesiva brevedad de términos procesales y cumplimientos e incumplimiento de términos. En tal sentido será referido en primer lugar el debido proceso, para posteriormente relacionar el tema con los términos procesales. Así las cosas, es preciso mencionar que toda clase actuaciones bien sea judiciales o administrativas deben contar por lo mínimo con las garantías del derecho de defensa, contradicción, doble instancia, publicidad y juez natural, entre otros. Mencionado lo anterior la Corte conociendo de una demanda de inconstitucionalidad del artículo 59 de la Ley 1476 de 2011, "Por la cual se expide el régimen de responsabilidad administrativa por pérdida o daño de bienes de

propiedad o al servicio del Ministerio de Defensa Nacional, sus entidades adscritas o vinculadas o la Fuerza Pública”, mediante la Sentencia C-136 de 2016, Magistrado Ponente Doctor Luis Ernesto Vargas Silva, sostuvo:

"De conformidad con el artículo 29 de la Constitución, el debido proceso debe aplicarse a toda clase de actuaciones judiciales y administrativas, lo cual supone la obligación para jueces y autoridades administrativas de actuar con sujeción y respeto a esa prerrogativa, especialmente en la producción de decisiones que creen cargas, derechos, beneficios, sanciones, obligaciones y, en general, alteren posiciones jurídicas de particulares. Según la jurisprudencia constitucional, la función judicial y administrativa debe observar los cauces fijados en la ley y los reglamentos 
"con el fin de preservar las garantías -derechos y obligaciones- de quienes se encuentran incursos en una relación jurídica, en todos aquellos casos en que la actuación conduzca a la creación, modificación o extinción de un derecho o a la imposición de una sanción”.

De igual forma para la Corte Constitucional el debido proceso funciona como una limitante a la discrecionalidad de las autoridades con potestades administrativas, restringiendo de esta forma los poderes del Estado y evitando toda clase de abusos o arbitrariedades para con los particulares. Por consiguiente esto ha dicho la Corte:

“ La Corte de manera reiterada ha sostenido la concepción según la cual el debido proceso es "la regulación jurídica que de manera previa limita los poderes del Estado y establece las garantías de protección a los derechos de los individuos, de modo que ninguna de las actuaciones de las autoridades públicas dependa de su propio arbitrio, sino que se encuentren sujetas a los procedimientos señalados en la ley ... exige de las autoridades públicas la sujeción de sus actuaciones a los procedimientos previamente establecidos, ajenos a su propio arbitrio y destinados a preservar las garantías sustanciales y procedimentales previstas en la Constitución y en la ley".

En tal sentido el debido proceso debe ser visto como una representación estructurada de las garantías constitucionales que toda autoridad debe obligatoriamente seguir. Por lo anterior esto ha indicado la Corte:

"A la luz de lo anterior, por debido proceso pueden entenderse las formas y los procedimientos, previamente establecidos en el ordenamiento jurídico, que forzosamente deben ser seguidos en la sustanciación y resolución de cualquier asunto que comprometa derechos o bienes de las personas. Ante todo desempeña la función de limitar el ejercicio del poder jurisdiccional y la potestad decisoria de ciertos particulares, a fin de salvaguardar al individuo de usos abusivos de tales atribuciones, mediante la fijación de un conjunto de garantías. El debido proceso se caracteriza, en consecuencia, por dos elementos fundamentales: por un lado, es una particular manifestación del principio de legalidad y, por el otro, un esquema estructurado de garantías".

El debido proceso, según la Corte es una prolongación del principio de legalidad, toda vez que bajo reglas claras previamente establecidas por el legislador, se protege al individuo de arbitrariedades en el marco de las actuaciones judiciales o administrativas, permitiendo la materialización de las dimensiones que consagra el debido proceso. Por consiguiente esto ha mencionado la Corte Constitucional: 
"Es una prolongación específica del principio de legalidad, puesto que implica actuaciones conforme reglas preexistentes y, de esta manera, ampara al individuo contra formas ad hoc de adelantar trámites y adoptar decisiones o de investigar y juzgar. Pero, por otra parte, puesto que no constituiría una verdadera tutela de la persona proceder conforme reglas previas que en sí mismo sean arbitrarias, el debido proceso comporta un presupuesto de cierta manera sustantivo, pues esas fases con arreglo a las cuales se adelanta la actuación judicial o administrativa deben estar precedidas de una serie de garantías, precisamente, procesales, tales como, según la Constitución, la estricta tipicidad, la presunción de inocencia, la favorabilidad, el juez natural, el derecho de defensa, la prontitud razonable de las decisiones, la contradicción probatoria, la doble instancia, el non bis in ídem, la publicidad, entre otras.

Sobre las anteriores bases, ha dicho la Corte, el derecho al debido proceso hace posible "la defensa y preservación del valor de la justicia material, a través del logro de los fines esenciales del Estado, como la convivencia social y la protección de todas las personas residentes en Colombia en su vida, honra, bienes y demás derechos y libertades públicas (preámbulo y artículos $1^{\circ}$ y $2^{\circ}$ de la C.P)”.

Refiriéndose al debido proceso administrativo, la Corporación Constitucional, expresa que los procedimientos administrativos están gobernados por las mismas garantías procesales

que guardan las actuaciones judiciales. Ante lo cual esto ha mencionado esa Corporación:

"Ahora bien, como se ha dicho, también las autoridades administrativas están obligadas a proceder con sujeción al debido proceso. La iniciación de los procedimientos administrativos, su desarrollo, la formación de los actos administrativos, su ejecución y aplicación y, de manera general, toda manifestación de la administración pública está gobernada por el principio de legalidad y por las mismas garantías procesales que, conforme al tipo de actuación de que se trate, se hallan presentes en los procesos judiciales. Adicionalmente, puesto que el funcionamiento de la administración está fundado en el servicio al interés general y debe desarrollarse con base en los principios de igualdad, moralidad, eficacia, economía, celeridad, imparcialidad y publicidad (art. 209 de la Constitución), al cumplimiento de estos presupuestos obliga también el debido proceso administrativo".

La Corte, realiza un paralelo entre el particular y la administración, indicando que ambas partes se encuentran cobijadas bajo el principio del debido proceso, toda vez que le imprime deberes y derechos a ambos, habida cuenta que el primero en mención posee garantías que deben a su vez ser materializadas, en tanto las manifestaciones del segundo están cobijadas por este principio. Al respecto la Corte menciona:

"De modo particular, la jurisprudencia constitucional ha sostenido que dadas las especificidades
de los trámites y procesos que adelanta la administración, del debido proceso se siguen
básicamente dos órdenes de consecuencias relevantes para las Entidades y el administrado:
"[d]esde la perspectiva de los asociados, del derecho al debido proceso se desprenden las 
garantías de (i) conocer las actuaciones de la administración; (ii) pedir y controvertir las pruebas; (iii) ejercer con plenitud su derecho de defensa; (iv) impugnar los actos administrativos, y (v) gozar de las demás garantías establecidas en su beneficio. En lo que respecta a la administración, todas las manifestaciones del ejercicio de la función pública administrativa se encuentran cobijadas por el debido proceso, tales como (i) la formación y ejecución de actos administrativos; (ii) las peticiones presentadas por los particulares; y (iii) los procesos que se adelanten contra la administración por los ciudadanos en ejercicio legítimo de su derecho de defensa".

En tal sentido el debido proceso busca brindar seguridad jurídica a toda clase de

actuaciones judiciales o administrativas, es decir reglas claras previamente establecidas a

través de la cual se blinden los procedimientos en el marco de las investigaciones. Sobre el

particular esto ha resumido la Corte:

"En resumen, el derecho constitucional fundamental al debido proceso, por un lado, se funda en su sentido más general en el seguimiento de reglas preexistentes acerca del modo en que debe ser adelantado un procedimiento, de tal manera que el individuo tenga seguridad de sus términos y no vaya a ser sorprendido con reglas ex post facto; $y$, por otro lado, supone que las formas propias de cada juicio cuenten mínimamente con las garantías de defensa, contradicción probatoria, doble instancia, publicidad y juez natural. Estas mismas, en cuanto se ajusten a cada tipo de trámite, amparan al individuo ante la administración pública, que, en el desarrollo de trámites propios de sus funciones, en la formación y producción de actos jurídicos y en los procesos iniciados a demanda del administrado, debe respetar el debido proceso".

Con relación del análisis que la Corte Constitucional realizó a una demanda de inconstitucionalidad precisamente por el principio al debido proceso, expuesta al comienzo del presente trabajo, en la cual dicha Corporación, esa vez decidió declarar la inexequilidad del contenido de las normas acusadas al considerarlas contrarias al ordenamiento constitucional por ser violatorias del debido proceso, defensa y publicidad, al respecto esto dijo:

"el derecho al debido proceso hace posible "la defensa y preservación del valor de la justicia material, a través del logro de los fines esenciales del Estado, como la convivencia social y la protección de todas las personas residentes en Colombia en su vida, honra, bienes y demás derechos y libertades públicas (preámbulo y artículos $1^{\circ}$ y $2^{\circ}$ de la C.P) ”,

Como se observa, la Corte Constitucional en materia de debido proceso, establece una postura muy importante sobre este principio Superior, al referirse a los escenarios judiciales 
y administrativos y el manejo que se le debe dar a toda clase de actuaciones, donde se generen juicios de reproches de las personas.

Relacionando lo anterior, se estudiarán tres aspectos importantes en lo que tiene que ver con los términos procesales, entre los cuales se encuentran: (i) el plazo razonable, (ii) excesiva brevedad de los términos procesales de cara a las investigaciones en los escenarios administrativos o judiciales y (iii) incumplimientos en cuanto a los términos procesales, relacionados con las actuaciones que deben adelantar los funcionarios competentes al interior de cada proceso. En ese orden de ideas, se abordará el primer tema planteado, para lo cual se trae a relación a varios Magistrados de la Corte Constitucional, entre ellos: el doctor Ciro Angarita Barón y el doctor Alejandro Martínez Caballero, los cuales en la sentencia C-557 de $1992^{64}$, mediante la cual se efectuó una revisión de carácter constitucional al Decreto No. 1156 de julio 10 de $1992^{65}$, realizando en esa oportunidad salvamento de voto. Toda vez que los magistrados en mención haciendo alusión al plazo razonable, y en lo concerniente a la presente temática, indicaron que el plazo razonable debe atender a criterios de dificultad en la consecución de las pruebas en los procesos. Es decir se colige que no basta solo con el término procesal que establece la ley en determina actuación, sino que a su vez se debe tener en cuenta un criterio material, es decir la dificultad a la hora de obtener la prueba, toda vez que ello va a permitir acercarse a la realidad de los hechos que se investigan. Posteriormente la misma Corporación mediante sentencia T-1249 de 2004 ${ }^{66}$, conociendo de una acción de tutela, a través de la cual una ciudadana solicitaba el amparo de los derechos fundamentales

\footnotetext{
${ }^{64}$ Expediente RE-007, Corte Constitucional, sala plena, sentencia C-557 de 1992, Salvamento de Voto de los Magistrados Ciro Angarita Barón y Alejandro Martínez Caballero.

${ }^{65}$ Decreto No. 1156 de julio 10 de 1992, "Por el cual se dictan disposiciones en relación con el procedimiento aplicable a los delitos de conocimiento de los jueces regionales".

${ }^{66}$ Expediente T-862026, Corte Constitucional, sentencia T-1249 de 2004. MP. Humberto Antonio Sierra Porto.
} 
constitucionales al debido proceso y acceso a la administración de justicia, indicó que el plazo razonable atiende a unos parámetros de: (i) complejidad del asunto, (ii) la actividad procesal del interesado, (iii) la conducta de las autoridades y (iv) el análisis global del procedimiento, nótese como la Corte Constitucional al igual que el Consejo de Estado, coinciden en establecer los anteriores parámetros. Sin embargo la Corte le agrega el componente de análisis global del procedimiento, entendido como un examen general que debe realizar la autoridad judicial o administrativa a cada caso en particular en aras de determinar la razonabilidad del plazo en el procedimiento que se adelanta y no caer en dilaciones injustificadas que afecten las garantías referidas al debido proceso.

En igual sentido se expresó el Máximo Tribunal Constitucional en Colombia a través de la sentencia T-647 de $2013^{67}$, siendo Magistrado Ponente el doctor Jorge Ignacio Pretelt Chaljub $^{68}$, al indicar que el plazo razonable está directamente relacionado con el debido proceso, el cual ha sido consagrado de manera expresa en el artículo 8.1 de la Convención Americana de Derechos Humanos el cual reza:

"Toda persona tiene derecho a ser oída, con las debidas garantías y dentro de un plazo razonable, por un juez o tribunal competente, independiente e imparcial, establecido con anterioridad por la ley, en la sustanciación de cualquier acusación penal formulada contra ella, o para la determinación de sus derechos y obligaciones de orden civil, laboral, fiscal o de cualquier otro carácter".

Al igual que la Corte Constitucional, la Corte Interamericana de Derechos Humanos ${ }^{69}$, ha establecido tres criterios similares que deben ser tenidos en cuenta para determinar la

\footnotetext{
${ }^{67}$ Véase otras sentencias de la Corte Constitucional C-840 de 2001, T-1249 de 2004, T-366 de 2005, C-1154 de 2005, T-297 de 2006, T-527 de 2009, T-267 de 2015, SU-394 de 2016 y T-328 de 2017.

${ }^{68}$ Expediente T - 3862748, Corte Constitucional, sentencia T-647 de 2013, MP. JORGE IGNACIO PRETELT CHALJUB.

69 Caso Salvador Chiriboga Vs. Ecuador., Caso Myrna Mack Chang Vs. Guatemala., Caso Genie Lacayo Vs. Nicaragua., Caso Forneron e Hija Vs. Argentina, Caso González Medina y familiares Vs. República Dominicana, Caso Ibsen Cárdenas e Ibsen Peña Vs. Bolivia, Caso Vélez Loor Vs. Panamá, Caso Chitay Nech y otros Vs. Guatemala., Caso López Mendoza Vs. Venezuela., Caso Fleury y otros Vs. Haití., Caso Atala Riffo y Niñas Vs. Chile., Caso Pacheco Teruel y otros Vs. Honduras.
} 
razonabilidad del plazo en los procesos así: (i) la complejidad del asunto, (ii) actividad procesal del interesado y (iii) la conducta de las autoridades nacionales ${ }^{70}$, dejando por fuera de estos criterios el aspecto global del proceso que incorpora la Corte Constitucional en Colombia.

Para el segundo planteamiento, se estudió una demanda de inconstitucionalidad ${ }^{71}$ presentada por un ciudadano ante la Corte Constitucional, quien alega excesiva brevedad de términos procesales establecidos en los artículos 578 y 579 de la ley 522 de 1999, Código Penal Militar, los cuales según el demandante son violatorios del debido proceso y el derecho a la igualdad. En dicho estudio el máximo órgano constitucional se vio abocado a resolver el problema jurídico, relacionado en saber si las normas que rigen el procedimiento especial contemplado en la norma en mención, dada la brevedad de sus términos procesales, son violatorios del derecho a la igualdad y debido proceso Constitucional. En ese sentido la Corte menciona:

"Buena parte de la eficacia que se predica de un ordenamiento jurídico como instrumento social encaminado a proteger los derechos fundamentales de los miembros de una comunidad y resolver los conflictos que se presentan entre diferentes actores sociales, depende de la existencia de principios que garanticen el debate razonado de los argumentos enfrentados, y permitan que las demandas y pretensiones que presentan los ciudadanos en defensa de sus intereses, puedan ser discutidas y resueltas sobre la base de procedimientos claramente establecidos por las normas jurídicas; de esta manera, se evita la incertidumbre o la arbitrariedad en la definición de los derechos reconocidos a los individuos por la Constitución y la ley. Desde esta perspectiva, la consagración del debido proceso como principio articulador de las controversias jurídicas es fundamental para asegurar la efectividad del derecho de defensa, no sólo en las actuaciones que comprometen a la autoridad y a los ciudadanos, sino también en el ámbito específico de la relación jurídica entre el Estado y sus servidores".

\footnotetext{
${ }^{70}$ Véase caso de las Hermanas Serrano Cruz vs. El Salvador.

${ }^{71}$ Corte Constitucional. Sentencia C-178 de 2002. Demanda de inconstitucionalidad contra de los artículos 578 y 579, parcial, de la Ley 522 de 1999 “por la cual se expide el Código Penal Militar”. MP. Dr. Manuel José Cepeda Espinosa. Actor. Edgard Peña Velásquez.
} 
De igual forma expresa dicha Corporación que un procedimiento debe respetar en todo momento y lugar las garantías referidas al debido proceso, debe establecer con claridad las etapas que le rigen, las oportunidades de intervención y ejercicio de la defensa y la presentación de los recursos a que haya lugar. Por consiguiente es violatorio un procedimiento que no establezca con claridad la estructura del proceso, toda vez que se gestaría un ámbito de ambigüedad que puede provocar en afectaciones al procesado, en tal sentido esto ha indicado la Corte:

"La regulación legal de un procedimiento especial en el ámbito de la justicia penal militar es inconstitucional si desconoce la estructura procesal que permite distinguir con claridad las etapas de investigación, acusación y juzgamiento y limita el derecho de defensa del procesado al no señalar, por ejemplo, los recursos que se pueden presentar contra el auto que niega la práctica de ciertas pruebas. Tal procedimiento también resulta contrario al contenido del artículo 29 de la Constitución Política cuando se estructura sobre la base de términos procesales abreviados que resultan irrazonables al impedir que tanto el juez como las partes cuenten con el tiempo suficiente para establecer la veracidad de los hechos que se investigan habida cuenta de su complejidad y la gravedad de la sanción imponible a sus autores".

Con base en los criterios planteados anteriormente la Corte resuelve declarar la inexequibilidad de los artículos demandados 578 y 579 de la ley 522 de 1999, al considerar que los mismos violan el debido proceso constitucional, toda vez que la normativa no es clara en cuanto a su estructura procesal. Es importante mencionar que la Corte enfatiza en aspectos muy importantes que atañen la realización de un proceso bien sea desde la órbita de lo penal o administrativo. Para el Máximo Tribunal Constitucional es importante la claridad de la estructura del proceso y el desarrollo del mismo, toda vez que ello permite que el proceso se delante de una manera adecuada y respetando siempre las garantías procesales. Respecto de lo anterior, exalta la Corte lo siguiente:

"Por esta vía, la violación de los derechos a la igualdad y al debido proceso por parte de los artículos acusados depende de la apreciación de (i.) las personas y actividades a las que se les aplica el procedimiento en cuestión, (ii.) el grado de incidencia de la regulación en la estructura del proceso penal, es decir, si la concreción de un procedimiento excepcional que establece términos distintos a los existentes en otras materias, impide el goce efectivo de los principios del 
debido proceso reconocidos en el artículo 29 de la Constitución y (iii.) la naturaleza de las conductas delictivas que se han de investigar y juzgar por tal procedimiento"

De igual forma la Corte enfatiza en el aspecto de la excesiva brevedad, dado que los términos procesales deben atender a criterios de razonabilidad, permitiendo que tanto el juez como las partes, dispongan del tiempo suficiente que les permita establecer con certeza la veracidad de los hechos que se investigan.

En lo que respecta al tercer planteamiento, el cumplimiento o incumplimiento de los términos procesales como lo ha mencionado la Corte Constitucional en varios pronunciamientos, está directamente relacionado con las garantías procesales y el respeto al debido proceso Constitucional, tal como lo menciona dicha Corporación en sentencia C-181 de $2002^{72}$ que a la letra dice:

"El acatamiento de las garantías intrínsecas al debido proceso tiene dos implicaciones en el campo concreto de los términos procesales, ya que éstos deben ser respetuosos del debido proceso, pero, además, la jerarquía constitucional del debido proceso impone al legislador la obligación de establecer términos procesales".

Los términos procesales en los escenarios o contextos judiciales o administrativos por lo general no son respectados, es decir a pesar de que existe una norma que le establece con claridad al juez o funcionario con competencia administrativa el deber de cumplir paso a paso una serie de actuaciones en unos tiempos previamente establecidos, la realidad es otra, toda vez que éstos no se cumplen y no se respetan, obviando el mandato del legislador. Sin embargo la Corte Constitucional, reitera que ha emitido varios pronunciamientos relacionados con el cumplimiento a los términos procesales, ello en garantía de la certeza y seguridad jurídica, debido proceso, celeridad y eficacia del derecho sustancial, así como lo

\footnotetext{
${ }^{72}$ Corte Constitucional. Demanda de inconstitucionalidad. Sentencia C- 181 de 2002. MS. Dr. Marco Gerardo Monroy Cabra.
} 
menciona el Máximo Tribunal en Auto No. $081^{73}$ de 2010, expediente D-8013, MP. Gabriel

Eduardo Mendoza Martelo, que a la letra dice:

"Con respecto a los términos procesales, esta Corporación ha indicado que "deben cumplirse diligente y celosamente por parte de quienes acceden a la administración de justicia, así como corresponde a los jueces y los auxiliares de la justicia velar por su cumplimiento, por cuanto es una carga procesal en cabeza de los primeros que busca garantizar la seguridad y certeza jurídicas, el debido proceso, el principio de celeridad y la eficacia del derecho sustantivo."

En igual sentido la misma Corporación emitió la Sentencia T- 030 de $2005^{74}$, mediante la cual le reitera el deber de cumplir con los términos procesales a todos los operadores jurídicos que hacen parte de la administración de justicia, en pro de las garantías referidas al debido proceso y en beneficio de los destinatarios de la administración de justicia, al respecto dijo la Corte:

"El Constituyente coherente con el reconocimiento que hizo de estas garantías estableció el siguiente mandato: "Los términos procesales se observaran con diligencia y su incumplimiento será sancionado" del cual se infiere, tal y como lo ha precisado esta Corporación desde sus primeras providencias, que "la Constitución Política de 1991 está inspirada, entre otros muchos, en el propósito definido de erradicar la indeseable costumbre, extendida entre los jueces pero también entre otros funcionarios públicos, de incumplir los términos procesales acarreando a los destinatarios de la administración de justicia toda suerte de perjuicios en el ejercicio de sus más elementales derechos."

Otro pronunciamiento importante por parte del máximo órgano constitucional es el efectuado mediante la sentencia T-604 de 2005, MP. Dr. Carlos Gaviria Díaz, en lo que respecta a las dilaciones injustificadas, dicho tribunal expresa que: "los términos procesales se observan con diligencia y su incumplimiento será sancionado”.

Puestos de presente todos los anteriores pronunciamientos del órgano que encabeza el control constitucional en el país, queda claro la postura de dicho órgano en lo que tiene que

\footnotetext{
${ }^{73}$ Corte Constitucional. Auto 081 de 2010, expediente D-8013. Recurso de súplica interpuesto contra el auto de 9 de marzo de 2010, dictado por el Magistrado Juan Carlos Henao Pérez, mediante el cual se rechazó la demanda presentada en el proceso de la referencia. Magistrado Ponente: Gabriel Eduardo Mendoza Martelo. Demandante. José Darismel Cortes Álvarez.

${ }^{74}$ Corte Constitucional. Sentencia T-030-2005. MP. Jaime Córdoba Triviño
} 
ver con los términos procesales. Corolario la Corte Constitucional tiene una postura firme sobre el cumplimiento de los términos en los escenarios administrativos, es decir que se deben respetar en garantía del debido proceso, seguridad y certeza jurídica y respeto por el derecho sustancial, de igual forma menciona dicha Corporación que se deben respetar y mantener siempre las estructuras que atañen a cada procedimiento, asimismo deben ser claras las etapas que las rigen. En tal sentido, surge la duda, de saber ¿qué sucede entonces en los escenarios administrativos cuando dichos términos se incumplen?, la respuesta claramente sería que nada, a pesar de que existen varios pronunciamientos del órgano de cierre en materia constitucional en Colombia. No obstante el legislador y la jurisprudencia ha querido que los operadores jurídicos, garanticen el respeto y cumplimiento de los términos en los procesos, para lo cual ha emitido normas que castigan el incumplimiento, tales como pérdida de competencia para conocer del proceso e investigaciones disciplinarias que pueden dar lugar a la pérdida del empleo a los funcionarios con competencia para actuar al interior de los $\operatorname{procesos}^{75}$, sin embargo no ha dado muchos resultados actualmente, toda vez que los despachos se siguen congestionando debido a la gran cantidad de procesos que siguen ingresando al sistema de administración de justicia.

Hasta este estado de la temática que se aborda, se han presentado varios temas muy relevantes, que han permitido ir dilucidando la pregunta problema, y de igual forma ha facilitado la posibilidad de presentar herramientas prácticas que permitirán presentar algunas alternativas de solución al tema objeto de estudio. Por tanto se hace necesario en la siguiente

\footnotetext{
${ }^{75}$ Ejemplo de ello es la ley 1395 de 2010, por medio de la cual se adoptan medidas en materia de descongestión judicial. Indica la norma ibídem, que en el evento que el juez deje trascurrir un año sin tomar una decisión de fondo del caso bajo estudio, perderá automáticamente la competencia para conocer del proceso, y remitir el expediente al juez o magistrado que le sigue en turno, quien dentro de un término de dos meses deberá proferir sentencia.
} 
sección, abordar aspectos fundamentales como lo son el práctico y el subjetivo, en aras de conocer su relación desde una óptica mucho más cercana, es decir, se podría interpretar como un escaneo que se efectúa a alguna superficie con el propósito de detectar y corregir hasta los detalles más mínimos del procedimiento abreviado de la Ley 1476 de 2011, en lo que respecta a cómo se gesta esa relación con la garantía referida al debido proceso constitucional, en lo concerniente al derecho de defensa técnica y material.

\section{SECCIÓN 2. EL ASPECTO PRÁCTICO Y SUBJETIVO QUE ENCIERRA EL PROCEDIMIENTO ABREVIADO Y SU RELACIÓN CON EL DEBIDO PROCESO}

Una de las maneras de establecer si el procedimiento abreviado, vulnera el debido proceso constitucional y atenta contra el principio de la dignidad humana, es sometiéndolo al análisis de casos que se hayan adelantado en los escenarios de las autoridades administrativas conforme el factor de competencia establecido en el artículo 21 de la Ley 1476 de 2011, dicho análisis se realizará con base en los criterios establecidos por la jurisprudencia del Consejo de Estado y de la Corte Constitucional antes vista y de igual forma se tendrá como referencia el planteamiento del libro titulado la decisión judicial: El debate Hart y Dworkin, escrito por Cesar Rodríguez, el cual está relacionado con la resolución de casos difíciles y la discrecionalidad judicial, en la que se ven abocados los jueces a la hora de resolver asuntos que conforme lo establece el escrito en mención brindan varias posibilidades de llegar a establecer una solución acertada al caso puesto bajo estudio. Para lo cual se analizará la óptica planteada por el segundo autor respecto de que "los principios son estándares que defienden un derecho individual" (Rodriguez, 1997, pág. 78), bajo esa perspectiva se determinará si los principios de dignidad humana y debido proceso fueron garantizados durante el desarrollo de las investigaciones que se relacionan a continuación, en amparo del derecho de defensa 
técnica y material y su alineación de igual forma con el derecho de presentar y controvertir pruebas, interponer alegatos de conclusión, presentar recursos y demás aspectos que enmarca dicho derecho.

\section{A. El procedimiento abreviado: análisis de casos desde la óptica del debido proceso a varias decisiones de la administración}

En este apartado se realizará el ejercicio de presentar casos prácticos llevados desde dos perspectivas: La primera de ellas relacionada con la aplicación literal de la norma, la cual será denominada para una mejor comprensión como casos tipo A, es decir se tomarán varias investigaciones donde se aplique el procedimiento abreviado de la Ley 1476 de 2011 y se desarrollen conforme lo establece en la actualidad el artículo 94 de la norma en mención. Por el contrario en la segunda perspectiva se mostrará el desarrollo del mismo procedimiento, denominados casos tipo $B$, no obstante esta vez garantizando principios constitucionales como la dignidad humana y el debido proceso, las cuales contemplan varias dimensiones tanto subjetivas como objetivas, que nos permitirán llegar a una conclusión y a su vez a una solución clara con base en el problema planteado. Así las cosas se le dará paso a los casos, no sin antes mencionar que los mismos atienden en su encabezado a casos reales que ya fueron resueltos por la autoridad encargada de adelantar las investigaciones, sin embargo varios de ellos fueron cambiados en su contenido de manera intencional en aras de descubrir el resultado que nos da el ceñirnos al contenido del referido artículo.

\section{Casos tipo A}

\section{Caso \# 1: Pérdida Placa de identificación Policial, bajo el radicado No. SIPAD-A- DERA-2013-01.}

1. El día 21 de mayo de 2013, informa el funcionario Patrullero de la Policía Nacional, que el día 27 de diciembre de 2011, resultó herido al ser objeto de una emboscada terrorista en el 
municipio de Saravena Arauca, siendo trasladado a la ciudad de Arauca para ser atendido por especialistas médicos, teniendo que dejar su morral de campaña donde se hallaba la placa policial número 052626. Informa el funcionario, que al regresar de la recuperación médica, cuando fue a revisar su morral de campaña, no encontrando su placa policial, desconociendo los motivos de su pérdida.

2. El día 22 de mayo de 2013, el funcionario con competencia administrativa, ordena la apertura de la investigación administrativa abreviada en contra del funcionario de la Policía Nacional Patrullero CRISTIAN CAMILO VARON RIOS, de igual forma notifica la decisión para la misma fecha al antes mencionado.

3. El día 23 de mayo de 2013, rinde descargos el investigado ante el funcionario con competencia administrativa, dentro de la investigación bajo radicado.

4. El día 24 de mayo de 2013, rinde declaración juramentada el señor Patrullero, RODRIGUEZ ROMERO MIGUEL ANGEL, quien se desempeñaba como secretario de la Unidad policial que hacía parte el Patrullero CRISTIN VARON.

5. El día 25 de mayo de 2013, se notifica ante el funcionario competente del dictamen del precio el funcionario investigado Patrullero de la Policía Nacional CRISTIAN VARON.

6. El despacho del funcionario competente, en lo que respecta al análisis y valoración jurídica probatoria, dispone: (i) del informe que da a conocer la novedad de la pérdida de la placa policial. (ii) constancia reporte pérdida de la placa policial. (iii) descargos rendido por parte del investigado Patrullero CRISTIAN VARON y (iv) Declaración juramentada, rendida por parte del Patrullero RODRIGUEZ ROMERO MIGUEL ANGEL, quien se desempeñaba como secretario del Grupo al que pertenecía para la época de los hechos el investigado.

7. El 27 de octubre de 2013, el despacho del funcionario con competencia administrativa, emite fallo de responsabilidad en única instancia en contra del Patrullero de la Policía Nacional CRISTIAN CAMILO VARON RIOS, responsabilizándolo por la pérdida de la placa de identificación policial, ordenando el pago de dicho elemento, el cual conforme lo establece el fallo, será descontado de los haberes que percibe el funcionario, respecto de los salarios y demás ingresos. Decisión que fue notificada al responsabilizado el 28 de octubre de 2013.

8. El funcionario de la Policía Nacional CRISTIAN VARON, no presentó recuro de reposición ante la decisión que lo declaró administrativamente responsable por la pérdida de la placa de identificación policial. 


\section{Caso \# 2: Daños ocasionados a un vehículo tipo buseta marca Chevrolet de propiedad de la Policía Nacional, bajo el radicado No. SIPAD-A- DERA-2016-14.}

1. El 02 de abril de 2016, fueron puestos los hechos en conocimiento de la administración, respecto de los daños causados a un vehículo tipo buseta de propiedad de la Policía Nacional de Colombia, al parecer por el Subintendente JULIO JOSUÉ GUERRERO MUÑOZ, conductor de mencionado automotor.

2. El 17 de agosto de 2016, el funcionario con competencia administrativa, emite auto mediante el cual ordena adelantar la investigación administrativa.

3. El 18 de agosto de 2016, fue notificado del inicio de la investigación administrativa el Subintendente de la Policía Nacional JULIO JOSUÉ GUERRERO MUÑOZ.

4. El 19 de agosto de 2016, le fue comunicado al investigado el precio de los daños causados al vehículo tipo buseta, objeto de investigación.

5. El 22 de agosto de 2016, rinde declaración juramentada la Patrullera de la Policía Nacional THALIA FERNANDA ROJAS FORERO. De igual forma el 23 de agosto rinde declaración juramentada la Patrullera SARA ALEJANDRA CORTES MOGOLLÓN. Ambas funcionarias hacían parte del dispositivo policial donde se encontraba el investigado.

6. El despacho del funcionario competente, en lo que respecta al análisis y valoración jurídica probatoria, dispone: (i) del informe que da a conocer los daños del vehículo tipo buseta. (ii) declaraciones juramentadas rendidas por las Patrulleras THALIA FERNANDA ROJAS FORERO y SARA ALEJANDRA CORTES MOGOLLÓN.

7. El 29 de agosto de 2013, el despacho del funcionario con competencia administrativa, emite fallo de responsabilidad en única instancia en contra el Subintendente de la Policía Nacional JULIO JOSUÉ GUERRERO MUÑOZ., Daños ocasionados a un vehículo tipo buseta marca Chevrolet de propiedad de la Policía Nacional

\section{Caso \# 3: Daños ocasionados a un vehículo tipo panel, radicado No. SIPAD-A- DEARA-2012-11.}

1. Tuvo su origen el día 8 de noviembre de 2012, cuando según lo informado por el señor Intendente MILAGROS ARQUIDIO VALBUENA SEPÚLVEDA, quien ostentaba para la época el cargo de Líder CAI Primero de Enero, se encontraba realizando patrullaje con el señor Patrullero ÓSCAR GARCÍA, conductor del vehículo tipo panel de placas LHA 549, cuando de repente una motocicleta conducida por una persona al parecer en estado de 
embriaguez, se les atraviesa, haciéndoles perder el control del vehículo, golpeándolo contra la rama de un árbol, partiéndosele el vidrio panorámico delantero.

2. El día 19 de noviembre 2012, el funcionario con competencia administrativa, ordena la apertura de la investigación administrativa abreviada.

3. El día 20 de noviembre de 2012, se elabora auto comisorio, suscrito por el funcionario competente, para que adelanten la diligencia de notificación al funcionario investigado, ello debido a que dicho funcionario se encuentra laborando en otra ciudad.

4. El día 21 de noviembre de 2012, los funcionarios de la Unidad comisionada, notificaron al investigado señor Patrullero ÓSCAR GARCÍA, del inicio de la investigación administrativa abreviada en su contra. De igual forma se le comunicó el valor del precio del bien que presuntamente daño.

5. El día 22 de noviembre del año 2012, el investigado presenta sus descargos con relación al proceso que se adelanta en su contra por el presunto daño a un vehículo tipo panel de propiedad de la Policía Nacional, cuando este fuera su conductor.

6. El día 23 de noviembre de 2012, se escuchó en declaración juramentada al señor Intendente de la Policía Nacional MILAGROS ARQUIDIO VALBUENA SEPÚLVEDA, quien se encontraba como tripulante del vehículo tipo panel, para la época en la cual se presentaron los hechos materia de investigación.

7. El despacho del funcionario competente, en lo que respecta al análisis y valoración jurídica probatoria, cuenta con el informe suscrito por el funcionario tripulante del vehículo Intendente MILAGROS ARQUIDIO VALBUENA SEPÚLVEDA, quien informa la novedad de los daños ocasionados al vehículo tipo panel de propiedad de la Policía Nacional.

8. El día 26 de noviembre de 2012, el despacho del funcionario competente, dicta y notifica fallo de responsabilidad de única instancia, dentro de la investigación administrativa abreviada que se adelantó en contra del señor Patrullero de la Policía Nacional ÓSCAR GARCÍA, responsabilizando a dicho investigado por los daños ocasionados a un vehículo tipo panel propiedad de la Policía Nacional de Colombia y en consecuencia se ordena dentro del fallo en su contra, se le descuente el valor del bien dañado del sueldo básico del funcionario o de las prestaciones que devengue por cualquier concepto. De igual forma dentro del mismo fallo, se le informa al funcionario responsabilizado administrativamente que le asiste el derecho de interponer el recurso de reposición ante la misma autoridad que profirió la decisión en su contra dentro de los cinco (05) días hábiles una vez le sea notificada la decisión. 
9. El día 27 de noviembre de 2012, el investigado presenta recurso de reposición ante la decisión de la administración de responsabilizarlo por los daños ocasionados al vehículo tipo panel de propiedad de la Policía Nacional.

10. El día 29 de diciembre de 2012, la administración resuelve confirmar la decisión tomada, y en consecuencia responsabilizar al señor Pt. ÓSCAR GARCIA, por los daños ocasionados al vehículo tipo panel de propiedad de la Policía Nacional.

\section{Caso \# 4: daños a un vehículo tipo panel (Laboratorio móvil de criminalística), radicado No. SIPAD-A- DERA-2012-12.}

1. El día 3 de septiembre de 2012, se informa de la novedad que presenta el vehículo tipo panel, utilizado como laboratorio móvil de criminalística, el cual presenta daños en el bómper o defensa de la parte delantera, representada en abolladuras y escarchamiento (sic) de la masilla.

2. El día 10 de septiembre de 2012, el funcionario con competencia administrativa, ordena la apertura de la investigación administrativa abreviada.

3. El 11 de septiembre de 2012, el funcionario con competencia administrativa, emite auto, declarando persona ausente.

4. El día 12 de septiembre de 2012, se posesiona ante el funcionario con competencia administrativa el defensor de oficio señor JUAN ALBERTO GONZALEZ TOVAR, reconociendo para la misma fecha personería jurídica a mencionado defensor, a quien de igual forma se le entregan copias del expediente.

5. El día 13 de septiembre de 2012, el funcionario con competencia administrativa, notifica al defensor de oficio JUAN ALBERTO GONZALEZ TOVAR, del inicio de la investigación administrativa bajo radicado No. SIPAD-A- DERA-2012-12.

6. El día 14 de septiembre de 2012, rinde declaración juramentada el señor Patrullero, NORBEY CAMILO MÉNDEZ CRUZ, ante funcionario comisionado.

7. El día 17 de septiembre de 2012, rinde declaración juramentada el señor Intendente CARLOS ARTURO SEQUEDA CARRERO, ante el funcionario con competencia administrativa.

8. El despacho del funcionario competente, en lo que respecta al análisis y valoración jurídica probatoria, dispone: (i) del informe suscrito por el Patrullero de la Policía Nacional NORBEY CAMILO MÉNDEZ CRUZ, quien informa al Jefe inmediato la novedad relacionada con los daños que presentaba el vehículo tipo panel (laboratorio móvil de criminalística). (ii) comunicación suscrita por el responsable de movilidad del Departamento de Policía Arauca, 
donde informa el valor real de los daños ocasionados al vehículo tipo panel (laboratorio móvil de criminalística). (iii) obra documento mediante el cual el investigado se compromete a subsanar los daños del vehículo tipo panel (laboratorio móvil de criminalística). (iv) obra declaración del Patrullero NORBEY CAMILO MÉNDEZ CRUZ, funcionario que dio aviso al jefe inmediato de la novedad que presentaba el vehículo objeto de investigación y (v) declaración rendida por parte del Intendente de la Policía Nacional CARLOS ARTURO SEQUEDA CARRERO, quien fungía para la época como jefe de movilidad del Departamento de Policía Arauca.

9. El día 21 de septiembre de 2012, el despacho del funcionario con competencia administrativa, emite fallo de responsabilidad en única instancia en contra del Patrullero (r) de la Policía Nacional JOSÉ RUBÉN LAGUADO PORTILLA, responsabilizándolo por los daños ocasionados al vehículo tipo panel utilizado como laboratorio móvil de criminalística. De igual forma para la misma fecha el despacho del funcionario con competencia administrativa notifica al defensor de oficio de la decisión, contra la cual procede el recurso de reposición.

10. El día 12 de septiembre de 2012, el funcionario con competencia administrativa dentro de la investigación de carácter abreviada que se adelantó en contra del funcionario Patrullero (r) de la Policía Nacional JOSÉ RUBÉN LAGUADO PORTILLA, deja constancia que la decisión notificada toma ejecutoria, quedando en firme la decisión, debido a que el defensor no presentó dentro de los términos legales el recurso de reposición.

\section{Caso \# 5: Daños ocasionados binocular propiedad de la Policía Nacional, investigación bajo el radicado No. SIPAD-A- DERA-2015-72.}

1. El día 2 de octubre de 2015, fueron puesto en conocimiento de la administración los hechos relacionados con los daños causados a binocular marca Steinner, predator 8X30, en la vereda la India Departamento de Santander. Indica el informe que el responsable del elemento se encontraba realizando un desplazamiento con relación a la labor de fase de erradicación en la vereda antes anotada, el elemento objeto de investigación sufrió una caída que le ocasionó una ruptura en la parte central, quedando dividido en dos partes.

2. El día 07 de noviembre de 2015 , el funcionario con competencia administrativa, ordena la apertura de la investigación administrativa abreviada en contra del funcionario de la Policía Nacional Patrullero JUAN CARLOS CASTILLA MEDINA, la cual le fue notificada el 08 de noviembre del 2015. 
3. El día 8 de noviembre de 2015, le fue comunicado el precio del bien objeto de investigación al Patrullero JUAN CARLOS CASTILLA MEDINA. De igual forma rinde descargos dentro de la investigación que se adelanta en su contra por los daños ocasionados al binocular marca Steinner.

4. El despacho del funcionario competente, en lo que respecta al análisis y valoración jurídica probatoria, dispone: (i) del informe que da a conocer la novedad del daño de los binoculares marca Steinner. (ii) declaraciones juramentadas por los funcionarios Intendente MILTON FIDEL SARMIENTO FUENTES, Comandante Sección EMCAR-DEARA-55-1. Declaración del Patrullero YOXER EDWARD CLAVIJO CUAJI. Declaración rendida por el Teniente JULIAN SÁNCHEZ SÁNCHEZ.

5. El día 12 de noviembre de 2015, el despacho del funcionario con competencia administrativa, emite fallo de responsabilidad en única instancia en contra del Patrullero JUAN CARLOS CASTILLA MEDINA, responsabilizándolo por los daños ocasionados binocular propiedad de la Policía Nacional. De igual forma para la misma fecha el despacho del funcionario con competencia administrativa notifica al investigado, contra la cual procede el recurso de reposición.

\section{Caso \# 6: Pérdida de esposas metálicas policiales marca HIATTS de propiedad de la Policía Nacional, investigación bajo el radicado No. SIPAD-A- DERA-2016-59.}

1. El 22 de febrero de 2016, fueron puesto en conocimiento de la administración los hechos ocurridos el 24 de diciembre de 2015, relacionados con la perdida de las esposas policiales metálicas marca HIATTS, de propiedad de la Policía Nacional. Indica el informe que se le prestó las esposas al Patrullero DANIEL OSWALDO ARIAS RINCON, sin que este hasta el momento las regrese al armerillo para proceder a sacarle improntas, ante su negativa de entregarlas, procede la comandancia a informar la novedad a la administración para que se adelanten las investigaciones a que correspondan.

2. El día 14 de marzo de 2016, el funcionario con competencia administrativa, ordena la apertura de la investigación administrativa abreviada en contra del funcionario de la Policía Nacional Patrullero DANIEL OSWALDO ARIAS RINCON, la cual le fue notificada el 15 de marzo de 2016. De igual forma para la fecha indicada le fue comunicado el precio del bien al investigado. 
3. El día 17 de marzo de 2016, el investigado rinde descargos ante el funcionario con competencia administrativa dentro de la investigación que se adelanta en su contra por la pérdida de las esposas metálicas policiales marca HIATTS propiedad de la Policía Nacional.

4. El despacho del funcionario competente, en lo que respecta al análisis y valoración jurídica probatoria, dispone: (i) del informe que da a conocer la novedad de la pérdida de las esposas policiales metálicas marca HIATTS. de propiedad de la Policía Nacional. (ii) declaración juramentada por el funcionario Patrullero de la Policía Nacional JOSE ALBERTO RINCON REY.

5. El 21 de marzo de 2016, el funcionario competente, decidió responsabilizar administrativamente al Patrullero de la Policía Nacional DANIEL OSWALDO ARIAS RINCON, por la pérdida de las esposas policiales metálicas marca HIATTS.

Analizados los anteriores casos, se puede llegar a la conclusión que el funcionario con competencia administrativa que adelantó las investigaciones de carácter abreviadas, vulneró el principio de la dignidad humana que establece el artículo $1^{\circ}$ de la Ley 1476 de 2011 , de igual forma varias dimensiones del debido proceso constitucional, entre ellas el derecho de defensa técnica y material, el derecho a recurrir las decisiones tomadas en el marco del desarrollo del proceso, presentar alegatos de conclusión y demás aspectos de la parte probatoria que son importantes para establecer la verdad procesal de cada asunto en particular, habida cuenta que fueron obviadas etapas como el cierre de la investigación, la cual se extiende al derecho de presentar recursos sobre dicha decisión y la posibilidad de solicitar prácticas de pruebas adicionales que considere el investigado son importantes para su defensa, a su vez no se requirió al investigado para que este presentara alegatos de conclusión como garantía del derecho de defensa técnica y material.

En la segunda perspectiva que se presenta, se analizarán varios casos donde se ejerce la facultad de investigar por la figura del procedimiento abreviado consagrado en el artículo 94 de la Ley 1476 de 2011, a hechos mediante los cuales se da a conocer la pérdida o daño de 
algún bienes de propiedad del ramo de la defensa nacional, con el propósito de plantear la manera adecuada de adelantar las investigaciones bajo la figura del procedimiento abreviado dentro de unos plazos razonables y sobre todo respetando el principio de dignidad humana establecido en el artículo $1^{\circ}$ de la precitada norma, de igual forma garantizar las dimensiones del debido proceso como lo es el derecho de defensa técnica y material, posibilitar la forma de recurrir las decisiones tomadas en el marco del desarrollo de la investigación, presentar recursos y controvertir los mismos, solicitar práctica de pruebas y presentar alegatos de conclusión como garantía del derecho de defensa.

\section{Casos tipo B}

\section{Caso \# 1: Pérdida Placa de identificación Policial, bajo el radicado No. SIPAD-A- DERA-2013-01.}

1. El día 21 de mayo de 2013, informa el funcionario Patrullero de la Policía Nacional, que el día 27 de diciembre de 2011, resulto herido al ser objeto de una emboscada terrorista en el municipio de Saravena Arauca, siendo trasladado a la ciudad de Arauca para ser atendido por especialistas médicos, teniendo que dejar su morral de campaña donde se hallaba la placa policial número 052626. Informa el funcionario, que al regresar de la recuperación médica, cuando fue a revisar su morral de campaña, no encontrando su placa policial, desconociendo los motivos de su pérdida.

2. El día 22 de mayo de 2013, el funcionario con competencia administrativa, ordena la apertura de la investigación administrativa abreviada en contra del funcionario de la Policía Nacional Patrullero CRISTIAN CAMILO VARON RIOS, de igual forma notifica la decisión para la misma fecha al antes mencionado.

3. El día 23 de mayo de 2013, rinde descargos el investigado ante el funcionario con competencia administrativa, dentro de la investigación bajo radicado.

4. El día 24 de mayo de 2013, rinde declaración juramentada el señor Patrullero, RODRIGUEZ ROMERO MIGUEL ANGEL, quien se desempeñaba como secretario de la Unidad policial que hacía parte el Patrullero CRISTIN VARON.

5. El día 24 de mayo de 2013, se notifica ante el funcionario competente del dictamen del precio el funcionario investigado Patrullero de la Policía Nacional CRISTIAN VARON. 
6. El día 27 de mayo de 2013, el funcionario con competencia administrativa declara cerrada la investigación de la referencia que se adelanta en contra el Patrullero CRISTIAN VARON, de igual forma para la misma fecha es notificado de la decisión del investigado en mención. Contra la cual procede el recurso de reposición, el cual deberá ser presentado dentro de los cinco (5) días hábiles siguientes a la notificación de presente decisión.

7. El día tres (3) de mayo de 2013, el funcionario con competencia administrativa deja constancia que transcurrido el término para presentar recurso de reposición ante la decisión de cerrar la presente investigación, el Patrullero CRISTINA VARON, investigado, no presentó recurso alguno quedando en firme dicho cierre, corriendo traslado para que el investigado Patrullero CRISTIAN VARON, presente sus alegato de conclusión, dentro de los cinco (5) días hábiles siguientes.

8. El día diez (10) de mayo de 2013, el despacho deja constancia que el investigado Patrullero CRISTIAN VARON, presenta dentro de los términos de ley sus alegatos de conclusión, los cuales conforme lo establece la ley 1476 de 2011 en su artículo 50, deberán ser valorados por el despacho.

9. El despacho del funcionario competente, en lo que respecta al análisis y valoración jurídica probatoria, dispone: (i) del informe que da a conocer la novedad de la pérdida de la placa policial. (ii) constancia reporte pérdida de la placa policial. (iii) descargos rendido por parte del investigado Patrullero CRISTIAN VARON y (iv) Declaración juramentada, rendida por parte del Patrullero RODRIGUEZ ROMERO MIGUEL ANGEL, quien se desempeñaba como secretario del Grupo al que pertenecía para la época de los hechos el investigado.

10. El 12 de julio de 2013, el despacho del funcionario con competencia administrativa, emite fallo de responsabilidad en única instancia en contra del Patrullero de la Policía Nacional CRISTIAN CAMILO VARON RIOS, responsabilizándolo por la pérdida de la placa de identificación policial, ordenando el pago de dicho elemento, el cual conforme lo establece el fallo, será descontado de los haberes que percibe el funcionario, respecto de los salarios y demás ingresos. Decisión que fue notificada al responsabilizado el día 15 julio de 2013. Contra la cual procede el recurso de reposición, el cual deberá ser presentado dentro de los cinco (5) días hábiles siguientes a la notificación de la presente decisión.

11. El día 22 de julio de 2013, el funcionario con competencia administrativa dentro de la investigación de la referencia, deja constancia que el Patrullero de la Policía Nacional CRISTIAN VARON, no presentó recuro de reposición ante la decisión que lo declaró administrativamente responsable por la pérdida de la placa de identificación policial, quedando debidamente ejecutoriada tal decisión. 


\section{Caso \# 2: Daños ocasionados a un vehículo tipo buseta marca Chevrolet de propiedad de la Policía Nacional, bajo el radicado No. SIPAD-A- DERA-2016-14.}

1. El 02 de abril de 2016, fueron puestos los hechos en conocimiento de la administración, respecto de los daños causados a un vehículo tipo buseta de propiedad de la Policía Nacional de Colombia, al parecer por el Subintendente JULIO JOSUÉ GUERRERO MUÑOZ, conductor de mencionado automotor.

2. El 17 de agosto de 2016, el funcionario con competencia administrativa, emite auto mediante el cual ordena adelantar la investigación administrativa.

3. El 18 de agosto de 2016, fue notificado del inicio de la investigación administrativa el Subintendente de la Policía Nacional JULIO JOSUÉ GUERRERO MUÑOZ.

4. El 19 de agosto de 2016, le fue comunicado al investigado el precio de los daños causados al vehículo tipo buseta, objeto de investigación.

5. El 22 de agosto de 2016, rinde declaración juramentada la Patrullera de la Policía Nacional THALIA FERNANDA ROJAS FORERO. De igual forma el 23 de agosto rinde declaración juramentada la Patrullera SARA ALEJANDRA CORTES MOGOLLÓN. Ambas funcionarias hacían parte del dispositivo policial donde se encontraba el investigado.

6. El día 25 de agosto de 2016, el funcionario con competencia administrativa declara cerrada la investigación de la referencia que se adelanta en contra del Subintendente de la Policía Nacional JULIO JOSUÉ GUERRERO MUÑOZ, de igual forma para la misma fecha es notificado de la decisión del investigado en mención. Contra la cual procede el recurso de reposición, el cual deberá ser presentado dentro de los cinco (5) días hábiles siguientes a la notificación de presente decisión.

7. El día dos (2) de septiembre de 2016, el funcionario con competencia administrativa deja constancia que transcurrido el término para presentar recurso de reposición ante la decisión de cerrar la presente investigación, el Subintendente de la Policía Nacional JULIO JOSUÉ GUERRERO MUÑOZ, investigado, no presentó recurso alguno quedando en firme dicho cierre, corriendo traslado para que de igual forma presente sus alegato de conclusión, dentro de los cinco (5) días hábiles siguientes.

8. El día doce (12) de mayo de 2016, el despacho deja constancia que el investigado Subintendente de la Policía Nacional JULIO JOSUÉ GUERRERO MUÑOZ, presenta dentro de los términos de ley sus alegatos de conclusión, los cuales conforme lo establece la ley 1476 de 2011 en su artículo 50, deberán ser valorados por el despacho. 
9. El despacho del funcionario competente, en lo que respecta al análisis y valoración jurídica probatoria, dispone: (i) del informe que da a conocer los daños del vehículo tipo buseta. (ii) declaraciones juramentadas rendidas por las Patrulleras THALIA FERNANDA ROJAS FORERO y SARA ALEJANDRA CORTES MOGOLLÓN.

10. El día treinta 30 de septiembre de 2016, el despacho del funcionario con competencia administrativa, emite fallo de responsabilidad en única instancia en contra el Subintendente de la Policía Nacional JULIO JOSUÉ GUERRERO MUÑOZ., Daños ocasionados a un vehículo tipo buseta marca Chevrolet de propiedad de la Policía Nacional

\section{Caso \# 3: Daños ocasionados a un vehículo tipo panel, radicado No. SIPAD-A- DEARA-2012-11.}

1. Tuvo su origen el día 8 de noviembre de 2012, cuando según lo informado por el señor Intendente MILAGROS ARQUIDIO VALBUENA SEPÚLVEDA, quien ostentaba para la época el cargo de Líder CAI Primero de Enero, se encontraba realizando patrullaje con el señor Patrullero OSCAR GARCIA, conductor del vehículo tipo panel de placas LHA 549, cuando de repente una motocicleta conducida por una persona al parecer en estado de embriaguez, se les atraviesa, haciéndoles perder el control del vehículo, golpeándolo contra la rama de un árbol, partiéndosele el vidrio panorámico delantero.

2. El día 19 de noviembre 2012, el funcionario con competencia administrativa, ordena la apertura de la investigación administrativa abreviada.

3. El día 20 de noviembre de 2012, se elabora auto comisorio, suscrito por el funcionario competente, para que adelanten la diligencia de notificación al funcionario investigado, ello debido a que dicho funcionario se encuentra laborando en otra ciudad.

4. El día 21 de noviembre de 2012, los funcionarios de la Unidad comisionada, notificaron al investigado señor Patrullero ÓSCAR GARCÍA, del inicio de la investigación administrativa abreviada en su contra. De igual forma se le comunicó el valor del precio del bien que presuntamente daño.

5. El día 22 de noviembre del año 2012, el investigado presenta sus descargos con relación al proceso que se adelanta en su contra por el presunto daño a un vehículo tipo panel de propiedad de la Policía Nacional, cuando este fuera su conductor.

6. El día 23 de noviembre de 2012, se escuchó en declaración juramentada al señor Intendente de la Policía Nacional MILAGROS ARQUIDIO VALBUENA SEPÚLVEDA, quien se encontraba como tripulante del vehículo tipo panel, para la época en la cual se presentaron los hechos materia de investigación. 
7. El día 27 de noviembre de 2012, el funcionario con competencia administrativa declara cerrada la investigación de la referencia que se adelanta en contra del Patrullero ÓSCAR GARCÍA, de igual forma para la misma fecha es notificado de la decisión del investigado en mención. Contra la cual procede el recurso de reposición, el cual deberá ser presentado dentro de los cinco (5) días hábiles siguientes a la notificación de presente decisión.

8. El día cinco (5) de diciembre de 2012, el funcionario con competencia administrativa deja constancia que transcurrido el término para presentar recurso de reposición ante la decisión de cerrar la presente investigación, el Patrullero ÓSCAR GARCÍA, investigado, no presentó recurso alguno quedando en firme dicho cierre, corriendo traslado para que de igual forma presente sus alegato de conclusión, dentro de los cinco (5) días hábiles siguientes.

9. El día doce (12) de diciembre de 2012, el despacho deja constancia que el investigado Patrullero ÓSCAR GARCÍA, presenta dentro de los términos de ley sus alegatos de conclusión, los cuales conforme lo establece la ley 1476 de 2011 en su artículo 50, deberán ser valorados por el despacho.

10. El despacho del funcionario competente, en lo que respecta al análisis y valoración jurídica probatoria, cuenta con el informe suscrito por el funcionario tripulante del vehículo Intendente MILAGROS ARQUIDIO VALBUENA SEPÚLVEDA, quien informa la novedad de los daños ocasionados al vehículo tipo panel de propiedad de la Policía Nacional.

11. El día 26 de diciembre de 2012, el despacho del funcionario competente, dicta y notifica fallo de responsabilidad de única instancia, dentro de la investigación administrativa abreviada que se adelantó en contra del señor Patrullero de la Policía Nacional ÓSCAR GARCÍA, responsabilizando a dicho investigado por los daños ocasionados a un vehículo tipo panel propiedad de la Policía Nacional de Colombia y en consecuencia se ordena dentro del fallo en su contra, se le descuente el valor del bien dañado del sueldo básico del funcionario o de las prestaciones que devengue por cualquier concepto. De igual forma dentro del mismo fallo, se le informa al funcionario responsabilizado administrativamente que le asiste el derecho de interponer el recurso de reposición ante la misma autoridad que profirió la decisión en su contra dentro de los cinco (05) días hábiles una vez le sea notificada la decisión.

12. El día 2 de enero de 2013, el investigado presenta recurso de reposición ante la decisión de la administración de responsabilizarlo por los daños ocasionados al vehículo tipo panel de propiedad de la Policía Nacional.

13. El día 10 de enero de 2013, la administración resuelve confirmar la decisión tomada, y en consecuencia responsabilizar al señor Pt. ÓSCAR GARCÍA, por los daños ocasionados al vehículo tipo panel de propiedad de la Policía Nacional. 


\section{Caso \# 4: daños a un vehículo tipo panel (Laboratorio móvil de criminalística), radicado No. SIPAD-A- DERA-2012-12.}

1. El día 3 de septiembre de 2012, se informa de la novedad que presenta el vehículo tipo panel, utilizado como laboratorio móvil de criminalística, el cual presenta daños en el bómper o defensa de la parte delantera, representada en abolladuras y escarchamiento (sic) de la masilla.

2. El día 10 de septiembre de 2012, el funcionario con competencia administrativa, ordena la apertura de la investigación administrativa abreviada.

3. El 11 de septiembre de 2012, el funcionario con competencia administrativa, emite auto, declarando persona ausente.

4. El día 12 de septiembre de 2012, se posesiona ante el funcionario con competencia administrativa el defensor de oficio señor JUAN ALBERTO GONZALEZ TOVAR, reconociendo para la misma fecha personería jurídica a mencionado defensor, a quien de igual forma se le entregan copias del expediente.

5. El día 13 de septiembre de 2012, el funcionario con competencia administrativa, notifica al defensor de oficio JUAN ALBERTO GONZALEZ TOVAR, del inicio de la investigación administrativa bajo radicado No. SIPAD-A- DERA-2012-12.

6. El día 14 de septiembre de 2012, rinde declaración juramentada el señor Patrullero, NORBEY CAMILO MÉNDEZ CRUZ, ante funcionario comisionado.

7. El día 17 de septiembre de 2012, rinde declaración juramentada el señor Intendente CARLOS ARTURO SEQUEDA CARRERO, ante el funcionario con competencia administrativa.

8. El día 20 de septiembre de 2012, el funcionario con competencia administrativa declara cerrada la investigación de la referencia que se adelanta en contra del Patrullero (r) de la Policía Nacional JOSÉ RUBÉN LAGUADO PORTILLA, de igual forma para la misma fecha es notificado de la decisión el defensor de oficio JUAN ALBERTO GONZALEZ TOVAR. Contra la cual procede el recurso de reposición, el cual deberá ser presentado dentro de los cinco (5) días hábiles siguientes a la notificación de presente decisión.

9. El día veintiocho (28) de septiembre de 2012, el funcionario con competencia administrativa deja constancia que transcurrido el término para presentar recurso de reposición ante la decisión de cerrar la presente investigación, el defensor de oficio, no presentó recurso alguno quedando en firme dicho cierre, corriendo traslado para que de igual forma presente sus alegato de conclusión, dentro de los cinco (5) días hábiles siguientes. 
10. El día dos (2) de octubre de 2012, el despacho deja constancia que el defensor de oficio JUAN ALBERTO GONZALEZ TOVAR, presenta dentro de los términos de ley sus alegatos de conclusión, los cuales conforme lo establece la ley 1476 de 2011 en su artículo 50, deberán ser valorados por el despacho.

11. El despacho del funcionario competente, en lo que respecta al análisis y valoración jurídica probatoria, dispone: (i) del informe suscrito por el Patrullero de la Policía Nacional NORBEY CAMILO MÉNDEZ CRUZ, quien informa al Jefe inmediato la novedad relacionada con los daños que presentaba el vehículo tipo panel (laboratorio móvil de criminalística). (ii) comunicación suscrita por el responsable de movilidad del Departamento de Policía Arauca, donde informa el valor real de los daños ocasionados al vehículo tipo panel (laboratorio móvil de criminalística). (iii) obra documento mediante el cual el investigado se compromete a subsanar los daños del vehículo tipo panel (laboratorio móvil de criminalística). (iv) obra declaración del Patrullero NORBEY CAMILO MENDEZ CRUZ, funcionario que dio aviso al jefe inmediato de la novedad que presentaba el vehículo objeto de investigación y (v) declaración rendida por parte del Intendente de la Policía Nacional CARLOS ARTURO SEQUEDA CARRERO, quien fungía para la época como jefe de movilidad del Departamento de Policía Arauca.

12. El día 11 de octubre de 2012, el despacho del funcionario con competencia administrativa, emite fallo de responsabilidad en única instancia en contra del Patrullero (r) de la Policía Nacional JOSÉ RUBÉN LAGUADO PORTILLA, responsabilizándolo por los daños ocasionados al vehículo tipo panel utilizado como laboratorio móvil de criminalística. De igual forma para la misma fecha el despacho del funcionario con competencia administrativa notifica al defensor de oficio de la decisión, contra la cual procede el recurso de reposición.

13. El día 19 de octubre de 2012, el funcionario con competencia administrativa dentro de la investigación de carácter abreviada que se adelantó en contra del funcionario Patrullero (r) de la Policía Nacional JOSÉ RUBÉN LAGUADO PORTILLA, deja constancia que la decisión notificada toma ejecutoria, quedando en firme la decisión, debido a que el defensor no presentó dentro de los términos legales el recurso de reposición.

\section{Caso \# 5: Daños ocasionados binocular propiedad de la Policía Nacional, investigación bajo el radicado No. SIPAD-A- DERA-2015-72.}

1. El día 2 de octubre de 2015, fueron puesto en conocimiento de la administración los hechos relacionados con los daños causados a binocular marca Steinner, predator 8X30, en la vereda 
la India Departamento de Santander. Indica el informe que el responsable del elemento se encontraba realizando un desplazamiento con relación a la labor de fase de erradicación en la vereda antes anotada, el elemento objeto de investigación sufrió una caída que le ocasionó una ruptura en la parte central, quedando dividido en dos partes.

2. El día cinco 5 de noviembre de 2015 , el funcionario con competencia administrativa, ordena la apertura de la investigación administrativa abreviada en contra del funcionario de la Policía Nacional Patrullero JUAN CARLOS CASTILLA MEDINA, la cual le fue notificada el 08 de noviembre del 2015.

3. El día 6 de noviembre de 2015, le fue comunicado el precio del bien objeto de investigación al Patrullero JUAN CARLOS CASTILLA MEDINA. De igual forma rinde descargos dentro de la investigación que se adelanta en su contra por los daños ocasionados al binocular marca Steinner.

4. El día 10 de noviembre de 2015, el funcionario con competencia administrativa declara cerrada la investigación de la referencia que se adelanta en contra del Patrullero JUAN CARLOS CASTILLA MEDINA, de igual forma para la misma fecha es notificado de la presente decisión. Contra la cual procede el recurso de reposición, el cual deberá ser presentado dentro de los cinco (5) días hábiles siguientes a la notificación de presente decisión.

5. El día dieciocho (18) de noviembre de 2015, el funcionario con competencia administrativa deja constancia que transcurrido el término para presentar recurso de reposición ante la decisión de cerrar la presente investigación, el investigado Patrullero JUAN CARLOS CASTILLA MEDINA, no presentó recurso alguno quedando en firme dicho cierre, corriendo traslado para que de igual forma presente sus alegato de conclusión, dentro de los cinco (5) días hábiles siguientes.

6. El día veinticuatro (24) de noviembre de 2015, el despacho deja constancia que el Patrullero JUAN CARLOS CASTILLA MEDINA, presenta dentro de los términos de ley sus alegatos de conclusión, los cuales conforme lo establece la ley 1476 de 2011 en su artículo 50, deberán ser valorados por el despacho.

7. El despacho del funcionario competente, en lo que respecta al análisis y valoración jurídica probatoria, dispone: (i) del informe que da a conocer la novedad del daño de los binoculares marca Steinner. (ii) declaraciones juramentadas por los funcionarios Intendente MILTON FIDEL SARMIENTO FUENTES, Comandante Sección EMCAR-DEARA-55-1. Declaración del Patrullero YOXER EDWARD CLAVIJO CUAJI. Declaración rendida por el Teniente JULIAN SÁNCHEZ SÁNCHEZ. 
8. El día cuatro (4) de diciembre de 2015, el despacho del funcionario con competencia administrativa, emite fallo de responsabilidad en única instancia en contra del Patrullero JUAN CARLOS CASTILLA MEDINA, responsabilizándolo por los daños ocasionados binocular propiedad de la Policía Nacional. De igual forma para la misma fecha el despacho del funcionario con competencia administrativa notifica al investigado, contra la cual procede el recurso de reposición, dentro de los cinco (5) días hábiles siguientes a la notificación de la actual decisión.

\section{Caso \# 6: Pérdida de esposas metálicas policiales marca HIATTS de propiedad de la Policía Nacional, investigación bajo el radicado No. SIPAD-A- DERA-2016-59.}

1. El 22 de febrero de 2016, fueron puesto en conocimiento de la administración los hechos ocurridos el 24 de diciembre de 2015, relacionados con la perdida de las esposas policiales metálicas marca HIATTS, de propiedad de la Policía Nacional. Indica el informe que se le prestó las esposas al Patrullero DANIEL OSWALDO ARIAS RINCON, sin que este hasta el momento las regrese al armerillo para proceder a sacarle improntas, ante su negativa de entregarlas, procede la comandancia a informar la novedad a la administración para que se adelanten las investigaciones a que correspondan.

2. El día 14 de marzo de 2016, el funcionario con competencia administrativa, ordena la apertura de la investigación administrativa abreviada en contra del funcionario de la Policía Nacional Patrullero DANIEL OSWALDO ARIAS RINCON, la cual le fue notificada el 15 de marzo de 2016. De igual forma para la fecha indicada le fue comunicado el precio del bien al investigado.

3. El día 17 de marzo de 2016, el investigado rinde descargos ante el funcionario con competencia administrativa dentro de la investigación que se adelanta en su contra por la pérdida de las esposas metálicas policiales marca HIATTS propiedad de la Policía Nacional.

4. El día 21 de marzo de 2016, el funcionario con competencia administrativa declara cerrada la investigación de la referencia que se adelanta en contra del Patrullero DANIEL OSWALDO ARIAS RINCON, de igual forma para la misma fecha es notificado de la presente decisión. Contra la cual procede el recurso de reposición, el cual deberá ser presentado dentro de los cinco (5) días hábiles siguientes a la notificación de la presente decisión.

5. El día veintinueve (29) de marzo de 2016, el funcionario con competencia administrativa deja constancia que transcurrido el término para presentar recurso de reposición ante la decisión 
de cerrar la presente investigación, el investigado Patrullero DANIEL OSWALDO ARIAS RINCON, no presentó recurso alguno quedando en firme dicho cierre, corriendo traslado para que de igual forma presente sus alegato de conclusión, dentro de los cinco (5) días hábiles siguientes.

6. El día cuatro (4) de abril de 2016, el despacho deja constancia que el Patrullero JUAN CARLOS CASTILLA MEDINA, presenta dentro de los términos de ley sus alegatos de conclusión, los cuales conforme lo establece la ley 1476 de 2011 en su artículo 50 ${ }^{76}$, deberán ser valorados por el despacho.

7. El despacho del funcionario competente, en lo que respecta al análisis y valoración jurídica probatoria, dispone: (i) del informe que da a conocer la novedad de la perdida de las esposas policiales metálicas marca HIATTS. de propiedad de la Policía Nacional. (ii) declaración juramentada por el funcionario Patrullero de la Policía Nacional JOSE ALBERTO RINCON REY.

9. El día dieciocho (18) de abril de 2016, el funcionario competente, decidió responsabilizar administrativamente al Patrullero de la Policía Nacional DANIEL OSWALDO ARIAS RINCON, por la pérdida de las esposas policiales metálicas marca HIATTS. De igual forma para el día 22 de abril de 2016 el despacho del funcionario con competencia administrativa notifica al investigado de dicha decisión, contra la cual procede el recurso de reposición, dentro de los cinco (5) días hábiles siguientes a su notificación.

Las investigaciones anteriormente expuestas, se adelantaron de la siguiente manera: (i) el funcionario con competencia administrativa procede en aperturar la investigación conforme lo establece el artículo 94 de la Ley 1476 de $2011^{77}$, (ii) de igual forma notifica al presunto responsable del bien puesto bajo su responsabilidad objeto de pérdida o daño del inicio de la investigación en su contra, (iii) asimismo realiza práctica de pruebas, (iv) posteriormente culminada esa fase, el funcionario competente notifica al investigado informándole que la etapa de pruebas está cerrada y que tiene la posibilidad de presentar el recurso de reposición ante tal decisión dentro de los cinco (5) días siguientes a la notificación de dicha decisión,

\footnotetext{
${ }^{76}$ Ibídem.

${ }^{77}$ Ibídem.
} 
(v) seguidamente de resolver si o no los recursos, (vi) procede a correr traslado al investigado para que éste presente sus alegatos de conclusión dentro de un término similar, con la misma posibilidad de seguir ejerciendo el derecho de defensa dentro de la investigación, (vii) culminada esa etapa, el funcionario competente procede a dictar fallo el cual a su vez se informa puede ser recurrido.

Del análisis de los casos antes expuestos, (tipo A y tipo B) se colige, respecto de los primeros, que las etapas surdidas en el desarrollo del procedimiento abreviado,

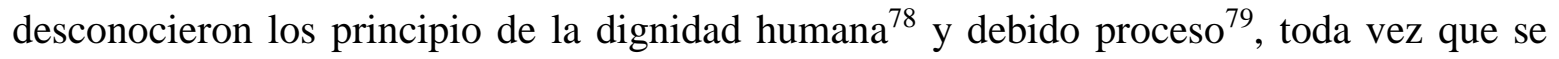
obviaron varias actuaciones que garantizarían la materialización de los mismos, dentro de esas actuaciones se obviaron: (i) la etapa del cierre de las investigaciones, (ii) informar del cierre al investigado y a su vez indicarle que le asiste el derecho de presentar recurso de reposición sobre tal decisión, además de poder solicitar práctica de pruebas adicionales que sean conducentes y pertinentes en garantía del derecho de defensa que le asiste, (iii) no se le corrió traslado a los investigados para presentar alegatos de conclusión como garantía extendida del derecho de defensa. Por tanto se plantea como forma de solución en aras de no generar afectaciones a las garantías constitucionales en el escenario del principio de la dignidad humana y debido proceso, a que se respeten aquellos derechos que se encuentran consignados en las normas que rigen los procedimientos, es decir, como se observa en los diferentes casos que se plantearon, el artículo 94 de la norma antes anotada, establece unas actuaciones, las cuales por si mismas vulneran el derecho a la defensa del investigado, por establecer tiempos muy cortos o ajustados, por tal motivo lo que se plantea es que a pesar de lo establecido en dicho artículo, se atienda el procedimiento, respetándole al investigado en

\footnotetext{
${ }^{78}$ Artículo $1^{\circ}$ Ley 1476 de 2011

${ }^{79}$ Artículo 29 Constitución Política de Colombia
} 
primer lugar el principio de la dignidad humana consagrado en el artículo $1^{\circ}$ de la norma en mención, el cual establece que quien intervenga en la actuación administrativa será tratado con el respeto debido a la dignidad humana inherente al ser humano, es decir bajo esta premisa de principios, se puede llegar a resolver aspectos que el artículo objeto de crítica no estableció en su literalidad normativa, dentro de los cuales se encuentra la de informarle al investigado del cierre de la investigación y que este a su vez le asiste el derecho de presentar recursos en contra de esa decisión y que además puede solicitar que se practiquen pruebas que se consideren pertinentes y conducentes para la defensa de sus intereses, asimismo la de brindarle la posibilidad al investigado de presentar alegatos de conclusión como garantía extendida al derecho de defensa técnica y material, derechos que hacen parte a su vez de las dimensiones del debido proceso.

\section{B. Planteamiento de un plazo razonable en el procedimiento abreviado que guarde garantías referidas al debido proceso}

Un plazo razonable, es aquel que respete siempre y en todo lugar la dignidad humana ${ }^{80} \mathrm{y}$ las garantías referidas al debido proceso constitucional, es aquel que permite que: (i) tanto la autoridad que investiga, como el investigado, dispongan de unos tiempos adecuados, razonables que garanticen a las partes involucradas practicar y presentar las pruebas necesarias para conocer la verdad material de los hechos que se investigan, (ii) generar de manera sana una contienda en lo que respecta a la contradicción de las pruebas que se presentan en contra y a favor del investigado, (iii) correr traslado para presentación de alegatos de conclusión y (iv) interposición de recursos. No obstante se debe tener en cuenta que se trata de un procedimiento que el legislador ha catalogado como abreviado, como su

${ }^{80}$ Artículo $1^{\circ}$ Ley 1476 de 2011 
nombre lo dice, debe realizarse de una manera mucho más rápida que un procedimiento ordinario, sin embargo por el hecho de ser "abreviado", no quiere decir que se desconozcan las garantías referidas al debido proceso, enfáticamente la vulneración al derecho de defensa. No obstante referente al planteamiento de casos, estos dieron las herramientas necesarias y suficientes para proponer cual sería el plazo razonable dada la aplicación del procedimiento abreviado establecido en el artículo 94 de la ley 1476 de $2011^{81}$, y se llega a la conclusión que el tiempo adecuado para surtir cada una de las etapas de las investigaciones administrativas de carácter abreviado previamente descritas lo establece el respeto y materialización de los principios decantados con anterioridad como la dignidad humana y el debido proceso, en ese orden de ideas cuando se investiga a un servidor público o persona en general por cualquier procedimiento independientemente de la jurisdicción, se le debe dar a conocer y notificar que se le está adelantando una investigación, mencionándole los derechos que le asisten como investigado ${ }^{82}$, de igual forma brindarle la oportunidad de rendir descargos libre de apremio y juramento ${ }^{83}$, asimismo en el marco del proceso se debe de abrir un periodo o etapa de pruebas, en ella tanto la administración representada por el funcionario con competencia administrativa y el investigado, tendrán la posibilidad de presentar y controvertir las pruebas que se presenten durante ese periodo, dicha etapa o periodo no debe ser en un tiempo muy corto, toda vez que se puede llegar a requerir conceptos técnicos o científicos para el esclarecimiento de los hechos, así como información que favorezca a las partes, por tal motivo debe contar con un tiempo prudente dada la naturaleza del asunto, posterior a ello se debe de cerrar esta etapa o periodo y darle a conocer al investigado de tal

\footnotetext{
${ }^{81}$ Ibídem

${ }^{82}$ Artículo $29 \mathrm{CN}$.

${ }^{83}$ Artículo $33 \mathrm{CN}$.
} 
decisión, con el propósito o fin de que éste cuente con la posibilidad de solicitar práctica de pruebas adicionales conforme la pertinencia y conducencia de las mismas, es decir la decisión de cierre de la etapa de pruebas debe estar sujeta a la interposición del recurso de reposición, de igual manera ya en la etapa final del procedimiento, el funcionario con competencia administrativa debe correrle traslado al investigado para que éste presente sus alegatos de conclusión en la investigación que se le adelanta, transcurrido todo este tiempo, el despacho debe valorar los alegatos presentados por el investigado y proceder en un plazo prudencial a dictar el fallo, el cual a su vez debe guardar la posibilidad de ser objeto de recursos. Groso modo se ha planteado el escenario acorde o adecuado para adelantar un procedimiento abreviado en la ley 1476 de 2011, que respete los principios como garantías constitucionales y legales, extendida al derecho de defensa técnica y material. Por consiguiente el procedimiento abreviado objeto de estudio puede ser adelantado en un periodo de treinta (30) a cuarenta (40) días, que es el plazo aproximado mediante el cual se surten las etapas de los procedimientos abreviados de la jurisdicciones disciplinaria y penal militar antes descritas, sin embargo como ya se ha demostrado conforme el análisis de la doctrina, la jurisprudencia y los casos planteados, se debe garantizar desde el inicio hasta el final los principios de dignidad humana y debido proceso, además se debe valorar aspectos como la complejidad del asunto, la cantidad de casos y los inconvenientes materiales que presenten los despachos. 


\section{CONCLUSIONES}

Sin duda alguna el procedimiento abreviado que se desarrolla en los escenarios jurídicos de la legislación Colombiana, ha sido una institución muy importante para acoger el conocimiento de varias situaciones que se presenten en la vida en sociedad, varias de esas situaciones o hechos presentados con anterioridad en todo el recorrido de la temática abordada, requieren de una mayor importancia o atención y en ello las normas no se quedan atrás, toda vez que le imprime la importancia que el asunto demande. Por tal razón hay eventos que por su complejidad, naturaleza o grado de importancia se adelantan por figuras jurídicas como las del procedimiento ordinario, es decir que sus tiempos, plazos o términos procesales son muchos más amplios y demandan una mayor atención, esta figura no fue analizada de fondo, debido a que no es el objeto de estudio central del trabajo presentado, sin embargo se trae a relación para conocer las diferencias entre las clases de procedimientos.

Por su parte en el estudio y análisis abordado en el capítulo primero del desarrollo temático, se abordaron aspectos generales y específicos importantes que rodean la figura jurídica del procedimiento abreviado, desde las ópticas de bien público, patrimonio público, y responsabilidad administrativa y fiscal. Respecto de la naturaleza del bien, por la cual se adelantan las investigaciones por pérdida o daño de bienes de propiedad del Ministerio de Defensa Nacional, sus entidades adscritas o vinculadas a la Fuerza Pública, los cuales son considerados por la legislación civil como bienes fiscales, es decir a diferencia de los bienes públicos o de uso público, estos si pueden ser sujetos de medidas jurídicas como embargos, secuestros y otras afectaciones que contempla la ley, toda vez que dichos bienes a pesar de

pertenecer al Estado, no tienen el carácter o categoría de imprescriptibles, inalienables e 
inembargables, como si se establece normativamente para los bienes de uso público. Asimismo el patrimonio de la nación cuenta con herramientas jurídicas que garantizan que su administración se efectúe de la mejor manera posible y que dichos recursos sean utilizados para el fin establecido, sin embargo a través de estas herramientas jurídicas, el Estado mediante sus entidades competentes, puede adelantar los procesos de responsabilidad fiscal a aquellos funcionarios que realicen una mala gestión de los recursos que el Estado les asigna para su debida administración. De igual forma los servidores públicos son responsable ante las autoridades por infringir la Constitución y la Ley, por la acción o la omisión en el ejercicio de sus funciones, así lo establece el artículo 90 de la norma Superior ${ }^{84}$, de igual forma y es importante relacionar que el Estado puede adelantar acciones de repetición en contra de sus agentes, es decir que en el evento de existir una acción dolosa o culposa de uno de ellos, el Estado mediante las herramientas legales puede resarcir ese menoscabo al erario de la nación.

Dada la dicotomía que por la misma naturaleza de la figura jurídica que se estudia, se planteó, que a pesar de las fortalezas o las debilidades del procedimiento abreviado, todos los autores o doctrinantes que se presentaron, coinciden en afirmar que dicho procedimiento permite o facilita que los asuntos se tramiten de forma más rápida y ágil, en ese sentido, asalta la duda respecto de saber si la vulneración de los principios de dignidad humana y debido proceso, están directamente relacionadas con los tiempos mediante los cuales se surten las etapas del procedimiento abreviado, incertidumbre que fue resuelta a través del estudio de la doctrina y la jurisprudencia del Consejo de Estado y de la Corte Constitucional, así como del estudio de los casos, logrando establecer que todo procedimiento o actuación administrativa

\footnotetext{
84 Artículo 90.El Estado responderá patrimonialmente por los daños antijurídicos que le sean imputables, causados por la acción o la omisión de las autoridades públicas.

En el evento de ser condenado el Estado a la reparación patrimonial de uno de tales daños, que haya sido consecuencia de la conducta dolosa o gravemente culposa de un agente suyo, aquel deberá repetir contra éste.
} 
o judicial, requiere del respeto de principios como garantías constitucionales y legales en aras de una adecuada práctica procesal, en tal sentido y conforme el análisis presentado la estructura actual del procedimiento abreviado de la ley 1476 de 2011 mediante la cual se surten las etapas requiere de tiempos más amplios que sin duda alguna superan los ocho (8) días que establece actualmente dicho procedimiento. Sin embargo dada la naturaleza misma de los hechos por los cuales se adelantan esta clase de actuaciones se requieren de etapas procesales mucho más expeditas en aras de brindar celeridad a los casos puestos bajo el conocimiento de los funcionarios con competencia administrativa, ante lo cual la exposición de motivos de la precitada norma se quedó corta al no presentar los argumentos relacionados con el porqué de la importancia de contar con una figura como la del procedimiento abreviado y los motivos por los cuales se decidió que dicho procedimiento fuera adelantado en tan solo ocho (8) días, situación que ha generado varios inconvenientes en el desarrollo de las investigaciones bajo la figura en comento, toda vez que se han visto afectados principios y derechos como la dignidad humana y el debido proceso, los cuales son claves para materializar las garantías constitucionales y legales en el marco de una actuación, no obstante sin desconocer que el ramo de la defensa nacional debe contar con herramientas que le permitan adelantar investigaciones dada la pérdida o el daño de un bien de su propiedad o que esté al servicio del mismo, el cual haya sido puesto bajo la custodia o cuidado de los hombres y mujeres que integran ese ministerio.

Por su parte las jurisdicciones disciplinarias y fiscal, a través de sus procedimientos abreviados, demostraron que se pueden surtir actuaciones en plazos mucho más adecuados, de los establecidos en la ley 1476 de 2011, garantizando además los principios de dignidad humana y debido proceso. 
Otro aspecto importante es el económico y de ello no se escapa de la esfera del análisis el procedimiento abreviado de la Ley 1476 de 2011, es preciso mencionar de entrada que es mucho más oneroso para el Estado investigar a través de esta figura jurídica, toda vez que muchos de los bienes no logran superar los dos (2) salarios mínimos legales mensuales vigentes, lo cual contrasta con los altos precios que se le pagan a los funcionarios además de correr con el sostenimiento de las actividades de los entornos administrativos para poner en marcha dicha labor, lo que comúnmente se conoce como coste fijo, no obstante el análisis visto, se estableció de igual forma que existe un coste variable en lo que tiene que ver con los ingresos de investigaciones bajo los radicados por año, lo cual significa que la tendencia al respecto es cambiante, en tal sentido como se manifestó en líneas anteriores la mejor decisión en materia de coste de oportunidad es continuar adelantando dichas investigaciones, toda vez que de no hacerlo se estaría enviando un mensaje negativo a los funcionarios de las entidades que conforman el ramo de la defensa nacional, situación que podría repercutir categóricamente en las finanzas de la Entidad y en la actitud de los agentes que la conforman. Por su parte quien ostenta la competencia administrativa para investigar la pérdida o daño de bienes de propiedad del ramo de la defensa nacional, puede exonerar al investigado, dependiendo de la causal que se aplique a cada caso en particular. Por consiguiente se establece que el uso legítimo del bien y su desgaste natural o su pérdida en el ejercicio de las funciones, no genera de inmediato una investigación dentro del marco de la Ley 1476 de 2011.

A su vez los teóricos como Ferraloji, López Toro, Carvajal y Taruffo, nos permitieron conocer la importancia de los principios de dignidad humana y debido proceso además de las dimensiones que este último integra, permitiendo con esto poder contar con reglas mucho más claras en los escenarios investigativos, toda vez que se convierten en referentes a la hora 
de tomar decisiones, habida cuenta que están en juego intereses tanto de particulares como colectivos y es deber de los funcionarios que administran justicia impartirla de la mejor forma.

Por su parte la Corte Constitucional y el Consejo de Estado, juegan un papel también importante en todo este desarrollo normativo social, toda vez que son estos órganos de cierre jurisprudencial que ayudan o permiten desentrañar toda clase complejidad que se plantea. Por consiguiente ambas instituciones son claras en asegurar que los términos procesales es un aspecto esencial en el desarrollo de un procedimiento y que tales términos deben ser garantizados por las normas y materializados por parte de los operadores jurídicos, no obstante se deben efectuar varios análisis: como la complejidad del asunto, la actividad procesal del investigado, y el análisis global del procedimiento. De igual forma las Cortes sancionan los incumplimientos o dilaciones injustificadas, sin embargo se analizan varios aspectos materiales que impiden que los términos procesales se cumplan a cabalidad, como la excesiva carga laboral, y falta de funcionarios para la tramitación de investigaciones. Asimismo son garantes de los derechos que enmarca el debido proceso constitucional, toda vez que dichas garantías son de obligatorio cumplimiento por parte de los funcionarios encargados de adelantar, tramitar y fallar asuntos que por su grado o naturaleza de su cargo o empleo deban tomar decisiones a favor o en contra de personas o funcionarios que por su labor o función se encuentren siendo investigadas sin importar la jurisdicción, es decir que las garantías del debido proceso se aplicarán a toda clase de actuaciones tanto judiciales como a las administrativas.

Por tanto se llega a la conclusión que el plazo razonable respecto de las actuaciones del procedimiento abreviado de la ley 1476 de 2011, se garantiza con el respeto a la dignidad 
humana y al debido proceso constitucional ${ }^{85}$, como escenario acorde a dicho procedimiento, el cual debe ser respetuoso, trasparente, claro, congruente y coherente con la realidad que se avoca, en tal escenario o contexto, el investigado una vez enterado que en contra de él se adelanta una investigación, debe contar con la posibilidad de ejercer su derecho a la defensa, bien sea desde el ámbito técnico o material, presentar y controvertir pruebas, alegatos de conclusión e interponer recursos. Si dichas garantías se cumplen, se estaría presente ante un procedimiento ideal, adecuado y acorde al escenario de contienda jurídica. Por consiguiente, es la misma materialización de estos principios que enmarca el tiempo o plazos de las etapas procesales.

Con base en los temas abordados en el presente de estudio, previo camino trazado a partir de la hipótesis, en la cual se planteó que los tiempos establecidos en el procedimiento abreviado de la ley 1476 de 2011, podrían ser violatorios del debido proceso y afectar el derecho a la defensa desde los ámbitos técnico o material, y el ejercicio de contradicción, y con base en el estudio de casos, la doctrina y la jurisprudencia, se ha logrado establecer una posible solución al problema jurídico planteado, que consiste en lo siguiente: en los casos analizados, donde se evidencia el desarrollo práctico del procedimiento abreviado, se presentaron dos escenarios, en el primero de ellos se aplicó la norma al pie de la letra, es decir evacuando los procesos en el plazo que la norma establece, ocho (8) días, situación que generó afectaciones a los principios de la dignidad humana y debido proceso, en detrimento de la dimensión del derecho de defensa técnica y material, así como el derecho de contradicción, toda vez que no permite que se genere una contienda adecuada, además que imposibilita la práctica de pruebas y la posibilidad por parte del investigado de ejercer una

\footnotetext{
${ }^{85}$ Articulo $29 \mathrm{CN}$.
} 
defensa acorde y adecuada, de igual forma tal como lo establece la precitada norma, no se le brinda la opción de oponerse al cierre de la corta etapa de pruebas que establece el procedimiento, de igual forma no se establece la posibilidad de presentar alegatos de conclusión, en suma y en aras de responder a la pregunta del planteamiento del problema, el procedimiento abreviado viola o vulnera los principios de dignidad humana y debido proceso, por ende el derecho de defensa y contradicción, conforme el análisis de los casos realizados. Por su parte, hipotéticamente se planteó un escenario de casos donde se aplicó el procedimiento abreviado de la Ley 1476 de 2011, mediante el cual se respetaron las garantías referidas al debido proceso, consistente en permitir al investigado presentar recurso de reposición ante la decisión de generar un cierre en la etapa probatoria, para lo cual el funcionario competente, otorgó el plazo que la misma ley establece para este evento, de igual forma se presentaron alegatos de conclusión, una vez culminada la etapa de pruebas, partiendo de que la norma es la que regula, además la administración conforme lo consagra la Ley, cuenta con un tiempo prudencial para emitir el fallo, en ese orden de ideas, la materialización de los principios nos brindan la solución al problema jurídico planteado, toda vez que la Ley 1476 de 2011 se rige por estos y por consiguiente el procedimiento abreviado regulado en el artículo 94 de la citada norma, así pues se planteó en ese sentido varias soluciones, la primera de ellas es que los operadores jurídicos respeten los principios mencionados desde todos sus aspectos, la segunda sería plantear la posibilidad de realizar una modificación al artículo 94 de la ley 1476 de 2011 en la que se amplíen sus términos o etapas, toda vez que su literalidad se reitera per se genera vulneraciones al debido proceso, generando una zona de interpretación amplia a varios operadores jurídicos, que sin duda alguna repercuten negativamente en los procesos que se adelantan en contra de los funcionarios que hacen parte del Ministerio de Defensa Nacional, sus Entidades adscritas o 
vinculadas a la Fuerza Pública, toda vez que el competente interpretaría la norma tal como se encuentra redactada y establecida. De igual forma se hace necesario que las entidades que desarrollan este procedimiento, se tomen la tarea de formar a sus funcionarios en lo que concierne al manejo acorde y adecuado de los bienes que les son puestos a su disposición para el ejercicio de sus funciones, en el entendido que tales bienes facilitan su labor y requieren de un especial cuidado y custodia, por ultimo sería viable que se generen capacitaciones a los funcionarios que hacen parte del desarrollo del procedimiento abreviado de la ley 1476 de 2011, desde un enfoque constitucionalista enfocado en principios, toda vez que esto va a permitir contar con funcionarios o servidores que entiendan la importancia y el rol que juega la dignidad humana y el debido proceso constitucional, así como el derecho de defensa y contradicción en las actuaciones judiciales o administrativas y que su desarrollo y garantía permite que los escenarios jurídicos donde se debaten esta clase de asuntos se desarrollen de manera acorde y adecuada a las prerrogativas constitucionales y legales. 


\section{ANEXO \# 1.}

\section{EXPOSICIÓN DE MOTIVOS LEY 1476 DE 2011 \\ ANTECEDENTES}

\section{GACETA DEL CONGRESO 444}

\section{3/07/2010}

El maestro Fernando Hinestrosa en el prólogo al libro "EL DAÑO" de JUAN CARLOS HENAO, expresa que la vida de relación de las personas comporta un doble riesgo permanente: dañar y ser dañado, por lo que el daño es un fenómeno inherente al ser humano. Existe un tipo de responsabilidad del servidor público mediante la cual debe responder por los daños o pérdidas que se causen a bienes del Estado, siendo esta responsabilidad diferente a la responsabilidad fiscal, siendo su fuente en el tiempo, como primera medida el Código Civil y después, la Constitución Nacional de 1991.

En los países que basan sus ordenamientos jurídicos en el Derecho Romano, especialmente Francia, se discutió si el Estado debía responder cuando uno de sus agentes ocasionaba daño a una persona. Esa controversia igualmente se dio en nuestro medio y sin norma constitucional que lo regulara, se comenzó una larga y promisoria interpretación de la normatividad contenida en el Código Civil que permitió concluir que el Estado era responsable por los daños que le causara a las personas, cuando este era generado por uno de sus agentes, sirviéndose para ello de los artículos 2341 y siguientes del Código Civil.

Como se observa, la responsabilidad que pudiéramos denominar administrativa y que consiste en la necesidad que el servidor público responda por los daños inferidos a los bienes, no se puede enmarcar dentro de la responsabilidad de naturaleza fiscal, disciplinaria, penal o de otra índole, que se derivaba de la propia Constitución de 1886 o de la ley, sino que su dogmática fue elaborada y construida en forma posterior por la jurisprudencia.

Siguiendo las enseñanzas jurisprudenciales de la época, se expidió por parte del señor Presidente de la República el Decreto número 1255 de 1961, primer reglamento del Ministerio de Defensa Nacional que consagra los ¿Procesos administrativos por pérdidas o daños de material de guerra $i$, reformado por el Decreto número 791 del 5 de abril de 1979, 
manteniéndose vigente hasta nuestros días, con la modificación que se suscitó en el año 2000 mediante el Decreto número 1932, en los temas de competencias y cuantías.

El Decreto número 791 del 5 de abril de 1979 por el cual se aprueba el Reglamento de "Procesos Administrativos por pérdidas o daños de los bienes destinados al servicio del Ramo de Defensa Nacional" expedido por el Gobierno Nacional de entonces, adoptó un cuerpo normativo en el tema específico, que se correspondía con las condiciones particulares de la responsabilidad administrativa en ese momento histórico.

Con el Decreto número 1932 de 2000, expedido por el Presidente de la República en uso de las facultades conferidas en el artículo 66 de la Ley $4^{\text {a }}$ de 1913, se modificó el Reglamento de Procesos Administrativos, en cuanto a las autoridades competentes para fallar las investigaciones administrativas que se adelanten por pérdida o daños de material de las instituciones señaladas.

Se ha considerado que el Decreto número 1255 de 1961 y sus posteriores modificaciones, se expidieron por el Presidente de la República en uso de las facultades legales conferidas en el artículo 66 de la Ley $4^{\text {a }}$ de 1913, sin embargo tal argumentación se queda corta en la actualidad con ocasión de la reserva legal que existe en la materia, como se desprende claramente del artículo $6^{\circ}$ de la Constitución Nacional, que estipula que los servidores públicos son responsables por infringir la Constitución o la ley, no teniendo los decretos aludidos dicha categoría. Igualmente el artículo 124 de la Constitución de 1991, consagra que La ley determinará la responsabilidad de los servidores públicos y la manera de hacerla efectiva.

Llegados a este punto se puede observar claramente que existe una necesidad imperiosa para que la responsabilidad que se le pueda endilgar al servidor público que labora en el Ministerio de Defensa y que ocasiona daños a sus bienes, sea regulada a través de una ley, de acuerdo a la reserva legal que emana diáfanamente de los artículos $6^{\circ}$ y 124 de la Constitución Nacional. Pasando a otro punto de análisis en nuestros antecedentes, se procederá a abordar el punto de si es la responsabilidad que denominamos administrativa lo mismo que la responsabilidad fiscal, porque si es semejante, no es dable que se pretenda que el Ministerio de Defensa se arrogue competencias que por Constitución le pertenecen a la Contraloría General de la República. 
La función controladora y de vigilancia tiene raíces profundas en nuestro pasado histórico que se remontan al propio descubrimiento de América, prosigue con la conquista y la colonia pues en los siglos XVI, XVII y XVIII la corona siempre se preocupó por el control de los fondos y bienes que los reyes poseían en los territorios sometidos ${ }^{[1][1]}$.

Ya con la independencia y en desarrollo de la misión Kemmerer se expidió en el gobierno de Pedro Nel Ospina la Ley 42 de 1923, bajo una filosofía de control dirigido básicamente a adelantar un control jurídico contable de la manera como se utilizaban los bienes del Estado. Es importante indicar que a pesar de señalarse que la Contraloría tiene a su cargo la vigilancia de la gestión fiscal, el enfoque principal que se le brinda a dicha entidad es el netamente contable, lo cual se puede apreciar en los artículos 93 y 94 del Acto Legislativo de 1945 y de las funciones otorgadas al Contralor General de la República.

Tan solo con la expedición de la Ley 20 de 1975 y los decretos que se expidieron en desarrollo de dicha ley, como lo fueron los Decretos-ley 924 de 1976 y 925 de 1976, es que se desarrollan unos verdaderos procedimientos tendientes a establecer un control fiscal en Colombia. Es en desarrollo de dicha ley que se señalan los sistemas de control fiscal en las etapas de control previo, control perceptivo y control posterior.

La normatividad reseñada sirve para indicar que la vigilancia fiscal ha sido instrumentalizada en Colombia a partir de 1975 y que con anterioridad era nula la aplicación de tal teoría, por cuanto no hubo un desarrollo legal en tal sentido.

Con todo y ello, la labor de la Contraloría siguió teniendo una preponderancia jurídica y contable, habida cuenta que con el Decreto Extraordinario 294 de 1973 -Estatuto Orgánico del Presupuesto General de la Nación-, se dispuso en el artículo 163 que las personas sujetas a control serían solidariamente responsables de los perjuicios que se ocasionaran cuando incurrieran en conductas, tales como contraer obligaciones, contabilizar o pagar obligaciones no autorizadas por la ley.

La Contraloría, quien en tal contexto adelantaba las investigaciones por responsabilidad fiscal, se encaminaba a evaluar la legalidad del gasto y sus aspectos financieros, por lo que la responsabilidad estaba dirigida a esos funcionarios (tesoreros, almacenistas, ordenadores del gasto, etc.), fundamentado sus procedimientos y elementos en la responsabilidad civil, porque no se había configurado autónomamente una dogmática de la responsabilidad fiscal. 
Lo importante del periodo que inicia con la Ley 42 de 1923 y termina con la expedición de la Constitución Nacional de 1991, es que se configura la vigilancia fiscal con los mismos elementos que sirven para determinar la responsabilidad civil, siempre y cuando se ocasionaren perjuicios en desarrollo de su gestión de tesoreros, almacenistas y ordenadores del gasto, en tanto y cuanto estuviesen obligados a rendir cuentas a la Contraloría General de la República.

Tal configuración de la Responsabilidad Fiscal es un elemento que no interesa a la Responsabilidad Administrativa y por lo mismo la identifica, pues ésta engloba a todo servidor público que ocasione daños a bienes del Estado. Asimismo, en la responsabilidad fiscal el daño debe resarcirse, debiéndose reconocer el daño en toda su dimensión y derroteros fijados por la jurisprudencia actual del Consejo de Estado, mientras que la responsabilidad administrativa obliga es a reponer el bien o pagar en dinero el valor de la pérdida o el daño. Los argumentos esbozados demuestran a las claras que la Responsabilidad Administrativa no es lo mismo que Responsabilidad Fiscal y que ante los mandatos del artículo $6^{\circ}$ de la Constitución Nacional, el tema conlleva necesariamente la expedición de una ley.

Halladas las razones por las cuales se hizo necesario presentar un proyecto de ley sobre el tema, se quiso aprovechar la coyuntura para ajustar el proceso administrativo por pérdida o daños de los bienes destinados al Ramo de la Defensa Nacional, a los postulados consagrados en la Constitución Política de 1991 y a los lineamientos modernos que implica el Derecho resarcitorio que conlleve a un adecuado ejercicio de la potestad administrativa.

En definitiva, constituye el objeto y propósito de este proyecto de ley, mejorar y perfeccionar el reglamento de procesos administrativos por pérdida o daños de los bienes destinados al Ramo de la Defensa Nacional, atendiendo las exigencias del proceso situado en el umbral del siglo XXI, el cual otorga al Ramo de la Defensa un instrumento eficaz sin menoscabo de las garantías y derechos reconocidos a toda persona.

BASE JURÍDICA: Se tiene como soporte de la responsabilidad por pérdida o daños de bienes pertenecientes al Ministerio de Defensa Nacional, las siguientes normas: 
CONSTITUCIÓN POLÍTICA: Los artículos $6^{\circ}$ y 124 que indican que la responsabilidad de los servidores públicos tiene reserva legal y responderán por infringir la Constitución Nacional y las leyes, así como por omitir o extralimitarse en el ejercicio de sus funciones. Artículo 90. Responsabilidad patrimonial por parte del Estado. No solamente se restringe a la acción de repetición, sino que abarca todo daño antijurídico que sea causado por la acción o la omisión de un servidor público, debiendo el servidor público responder patrimonialmente por su conducta dolosa o gravemente culposa.

Artículo 123. Define quiénes son servidores públicos, entre ellos sin lugar a dudas, los miembros de la Fuerza Pública.

LEYES: Ley 610 de 2000, por la cual se establece el trámite de los procesos de responsabilidad fiscal de competencia de las contralorías.

Esta ley es de gran importancia, porque permite distinguir con claridad cuál es la competencia de la Contraloría, en qué consiste la gestión fiscal y quiénes la ejercen, para diferenciarla de otras actividades que no conllevan dicha gestión, en las cuales también se pueden ocasionar daños o pérdidas, que generan detrimento al patrimonio pero que no serían de competencia de ese Órgano de Control:

Ley 87 de 1993, por la cual se establecen normas para el ejercicio del control interno en las entidades y organismos del Estado y se dictan otras disposiciones. De esta ley cabe destacar que el control interno se enfoca, entre otros aspectos principales a la buena administración y conservación de los recursos de las entidades, así:

Artículo $2^{\circ}$. OBJETIVOS DEL SISTEMA DE CONTROL INTERNO.

Literal a) proteger los recursos de la organización, buscando su adecuada administración ante posibles riesgos que los afecten.

Artículo $3^{\circ}$. ELEMENTOS PARA EL SISTEMA DE CONTROL INTERNO.

Literal e) adopción de normas para la protección y utilización racional de los recursos.

LEY 734 de 2002 por la cual se expide el Código Disciplinario Único.

DEBERES DE TODO SERVIDOR PÚBLICO

Artículo 34, numerales: 
21. Vigilar y salvaguardar los bienes y valores que le han sido encomendados y cuidar que sean utilizados debida y racionalmente, de conformidad con los fines a que han sido destinados.

22. Responder por la conservación de los útiles, equipos, muebles y bienes confiados a su guarda o administración y rendir cuenta oportuna de su utilización.

JURISPRUDENCIA: Sentencia C-840 de 2001. Corte Constitucional. Analiza la exequibilidad de algunos apartes de la Ley 610 de 2000. Distingue con precisión qué es la gestión fiscal y quiénes la realizan. Diferencia los daños que puedan causarse al patrimonio por actividades distintas de la gestión fiscal.

Concepto del Consejo de Estado, Sala de Consulta y Servicio Civil del 4 de agosto de 2003. Contiene un valioso fundamento constitucional y legal de la responsabilidad de los servidores públicos y la manera de hacerla efectiva. Distingue con gran claridad los diferentes eventos en que puede presentarse el daño al patrimonio público por daños o pérdida de bienes, entre ellas la gestión fiscal y la no gestión fiscal. Precisa la competencia de las Contralorías en asuntos propios de la gestión fiscal o con ocasión de la misma.

Realiza el análisis respecto de la posibilidad de hacer efectivo el resarcimiento a través de la acción disciplinaria para concluir que era posible en vigencia de la Ley 200 de 1995 como una sanción accesoria; pero que esta disposición fue derogada por la Ley 734 de 2002, en la cual ya no es posible tal mecanismo de reparación.

Concluye que en casos de pérdida o daño por actividades que no conlleven gestión fiscal se debe iniciar la acción penal o la acción contenciosa de reparación directa para obtener el resarcimiento del patrimonio estatal.

CONCLUSIONES: 1 . La acción administrativa por pérdida o daño de bienes de propiedad o al servicio del Ramo de la Defensa Nacional, tiene un sólido respaldo Constitucional, legal y jurisprudencial.

2. La acción administrativa presenta entre otras las siguientes características:

2.1. Es de naturaleza patrimonial.

2.2. Es resarcitoria y no sancionatoria ni punitiva

2.3. Es de carácter administrativo y no jurisdiccional. Está en cabeza del Estado y se ejerce por intermedio de autoridades administrativas. 


\subsection{Es una responsabilidad personal.}

2.5. El fundamento Su origen está en la pérdida o daño de bienes de propiedad o al servicio del Ramo de la Defensa Nacional.

2.6. Es independiente de las acciones penal, disciplinaria y fiscal.

2.7. No tiene relación con la gestión fiscal.

2.8. La fuente de obligación reside en la ley (en sentido amplio Constitución y ley), puede sostenerse también que tiene origen en la responsabilidad extracontractual.

2.9. Su objetivo es conservar, proteger o restablecer el patrimonio público.

2.10. Es de tipo subjetivo, es decir requiere los tres elementos constitutivos de la responsabilidad: daño, culpa y nexo causal; así como ausencia de circunstancias excluyentes de responsabilidad.

2.11. Hace parte de los mecanismos de control interno de las entidades.

2.12. Se desarrolla con fundamento en el principio general de responsabilidad de los servidores públicos (artículos $6^{\circ}$ y 124 de la Carta).

2.13. Es parte de las relaciones especiales de sujeción que con el Estado, tienen los servidores públicos en general y los miembros de la Fuerza Pública en particular.

3. Teniendo en cuenta que, por la naturaleza de sus funciones y la misión que cumple, la Fuerza Pública tiene régimen especial en los diferentes aspectos (penal, disciplinario, pensional, etc.), es razonable que también para estos casos se cuente con una herramienta legal que permita recuperar, en forma ágil, oportuna y eficaz, el patrimonio estatal e institucional cuandoquiera que se le ocasione un detrimento por pérdida o daño de sus bienes. 4. En igual sentido se debe tener en cuenta que muchos de los bienes referidos no se encuentran en el comercio (artículo 223 de la Carta), y que las investigaciones en este tipo de procesos generalmente tienen relación con asuntos propios de la Defensa Nacional y por lo tanto es conveniente y necesario que se mantenga la debida reserva y que los trámites se adelanten al interior de cada Fuerza, en virtud del principio del Juez Natural y del sistema de control interno que ya se mencionó.

5. Si bien es cierto el Consejo de Estado en el concepto del 4 de agosto de 2003, estima que en tratándose de pérdida o daño de bienes en actividades ajenas a la gestión fiscal se debe incoar la acción contenciosa de reparación directa, esta solución no es conveniente por dos 
razones fundamentales: primero porque resulta más oneroso (costo-beneficio), y demorado obtener el resarcimiento patrimonial a través de procesos en la Jurisdicción Contencioso Administrativa; que como es sabido tienen una duración superior a los cinco años (esto afectaría notoriamente la misión de la Fuerza Pública, pues muchos de los bienes, por ejemplo armamento, vehículos, radios de comunicación, son esenciales para el cumplimiento de sus funciones), y significa una alta inversión no sólo en cuanto a tiempo sino en otros recursos importantes para la entidad, verbi gratia el tener que contratar un equipo de abogados para que en todos los casos de pérdida o daño de bienes no generados en ejercicio de acción fiscal se entable la respectiva acción contenciosa. El segundo argumento es de orden práctico y real (prevalencia de lo sustancial sobre lo procesal): es un hecho notorio que en la actualidad el Consejo de Estado se encuentra en emergencia por el sinnúmero de procesos contenciosos que tiene a su cargo y por lo tanto, agregarle una carga más: la que se propone para el resarcimiento patrimonial, no solo de la Fuerza Pública, sino de todas las entidades estatales, forzosa y fatalmente desembocaría en un colapso de esta corporación.

Gabriel Silva Luján, Ministro de Defensa Nacional. 


\section{BIBLIOGRAFÍA}

Braña, F. J. (2004). Teoría de los bienes públicos y aplicaciones prácticas. Presentación de un número monográfico. Estudios de Economía Aplicada, 177-185.

Burbano, G. E. (2017). El procedimiento abreviado como una forma de descongestión del sistema judicial penal. Revista de la Facultad de Jurisprudencia, 191-227.

Carrillo Ballesteros, J. (2006). Del patrimonio público una aproximación al concepto y a su contenido. Prolegómenos, 23-34.

Carvajal, B. (2010). Alcance y limitaciones del debido proceso en el procedimiento administrativo. Revista digital de Derecho Administrativo, 7-21.

Catarino Rua, S. (2016). El reconocimiento de los bienes de dominio público: El caso de los municipios. Intangible Capital, 73-94.

Cordero, L. F. (2001). El procedimiento abreviado en la nueva Ley de la jurisdicción contencioso-administrativa. Universidad de salamanca, 1-6.

Correa Gómez, E., \& Pinzón Maldonado, H. (2012). RESPONSABILIDAD FISCAL EN COLOMBIA. Prolegómenos. Derechos y Valores, 173-188.

Dermisaky Peredo, P. (2012). LA RESPONSABILIDAD DE LOS SERVIDORES PÚBLICOS. Revista Boliviana de Derecho, 10-21.

Diccionario del Español Jurídico. (20 de 03 de 2016). inalienable, Imprescriptible, inembargable. Obtenido de Real Academia Española: http://dej.rae.es/\#/entry$\mathrm{id} / \mathrm{E} 136010$

Diccionario del Español Jurídico. (20 de 03 de 2016). Procedimiento administrativo abreviado. Obtenido de Real Academia Española: http://dej.rae.es/\#/entryid/E192470.

Ferrada Bórquez, J. C. (2007). LAS POTESTADES Y PRIVILEGIOS DE LA ADMINISTRACIÓN PÚBLICA EN EL RÉGIMEN ADMINISTRATIVO CHILENO. REVISTA DE DERECHO, 69-94.

Ferrajoli, L. (1995). Derecho y Razón, Teoría del Garantismo Penal. Madrid: Trotta, S.A.

Garcia De Enterría, E. (1954). Sobre la imprescriptibilidad del dominio público. Dialnet, 11-52.

Lopez Toro, W. (2002). El debido proceso. Pereira.

Lopez Toro, W. (2002). El debido Proceso. Pereira. 
Lopez Toro, W. (2002). El debido Proceso. Pereira.

Maier, J., \& Bovino, A. (2001). El procedimiento abreviado. Buenos Aires: Editores del Puerto s.r.l.

Marienhoff S, M. (1994). Tratado de Derecho Administrativo. Buenos Aires: AbeledoPerrot.

Marín Castán, M. L. (2007). La dignidad humana, los Derechos Humanos y los Derechos Constitucionales. Bioética y Derecho, 1-8.

Michelini, D. (2010). Dignidad humana en Kant y Habermas. Estudios de Filosofía Práctica e Historia de las Ideas, 41-49.

Natarén, N. C. (2011). Las "Salidas Alternas" en el diseño del nuevo proceso penal: breves notas desde la experiencia de la reforma en las entidades de la federación. Instituto de Investigaciones jurídicas de la UNAM, 99-108.

Nuñez, V. C. (17 de Febrero de 2016). El procedimiento Abreviado . Obtenido de V|lex: http://app.vlex.com.bdatos.usantotomas.edu.co:2048/\#WW/search/*/procedimiento +abreviado/p2/WW/vid/57294026.

Pimiento, J. A. (2011). Reflexiones en torno a la División de los bienes públicos en el Código Civil. Derecho Privado, 207-232.

Reales Vega, R. J. (2016). Estructura de las faltas disciplinarias en la Policía. Justicia, 158167.

Rodriguez, C. (1997). La decisión judicial El debate Hart - Dworkin. Bogotá: Siglo del Hombre.

Salvador Ma., M. V. (2010). Formularios de Procedimientos Administrativos. ValladolidEspaña: Lex Nova S.A.

Samuelson, P. A., \& Nordhaus, W. D. (1948). Economía. En P. A. Nordhaus, Economía (pág. 753). Mexico: Mc Graw Hill.

Soler Pedroza, I., \& Jiménez, W. G. (2009). La acción de repetición como mecanismo moralizadorde la función pública: luces y sombras. Estado del arte. Civilizar. Ciencias Sociales y Humanas, 73-89.

Taruffo, M. (2008). La Prueba, Artículos y Conferencias. Santiago: Metropolitana.

Vanestralen, H. (2004). Bienes de titularidad pública: patrimoniales y de dominio público. Una aproximación al sistema. Revista Estudios Socio-Jurídicos, 211-262.

Zamora, P. J. (20 de diciembre de 2016). Los peligros del procedimiento abreviado. Obtenido de V|lex : https://doctrina.vlex.com.mx/vid/peligros-procedimientoabreviado-410400454 